\title{
المسئولية التقصيرية عن التدخل في العلاقات التعاقدية في القانون الأهريكي
}

\author{
shel \\ د / حسام الدين محمود حسن \\ مدرس القانون المدني \\ كليتالحقوق- جامعت المنصورة
}




\section{المقدهة}

تنقسم المسئولية المدنية إلى نوعين، الأول: وهو المسئولية العقدية، وهي

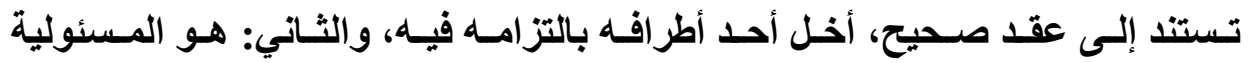

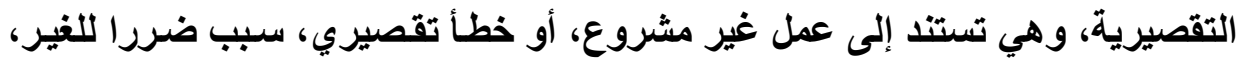

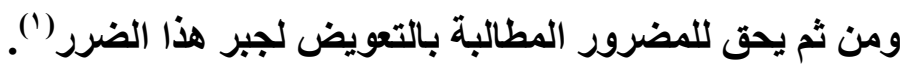

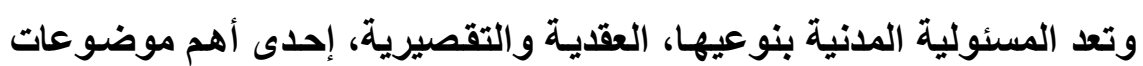

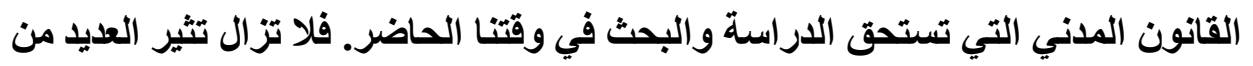

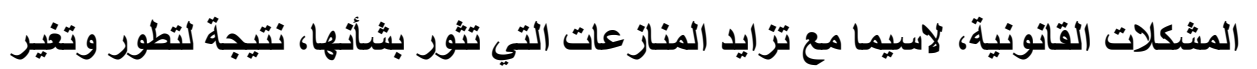

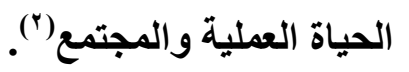

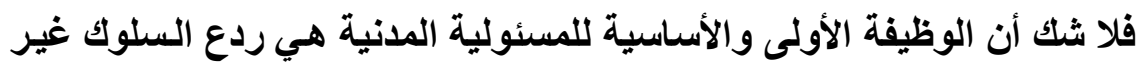

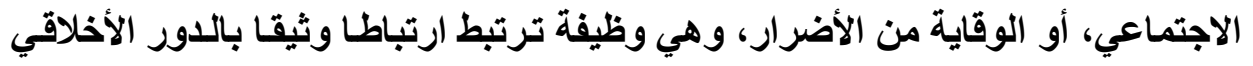
للمسئولية المدنية أكثر من وظيفتها التعويضية(").

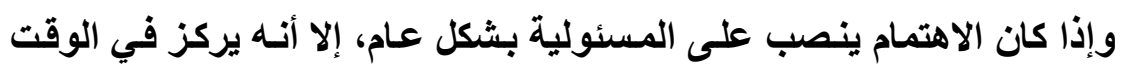

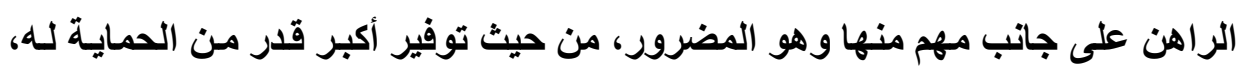

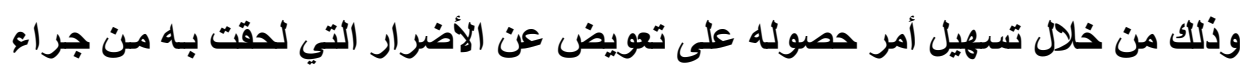

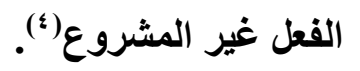
( ) عبد الحكم فوده، الخطأ في نطاق المسئولية التقصيرية، دار الفكر الجـامعي، الطبعة الأولى،

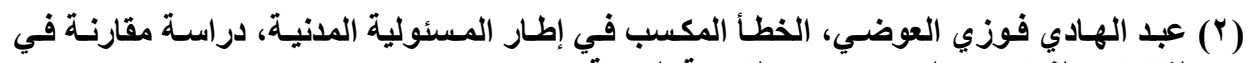

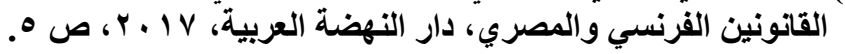

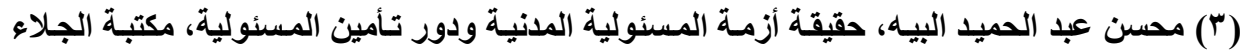

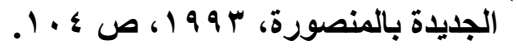

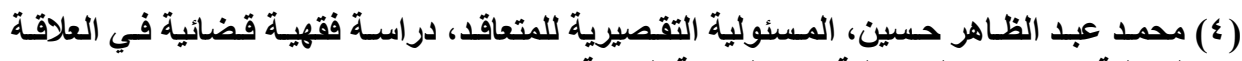

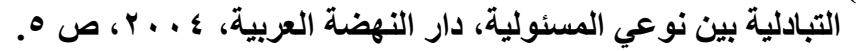


حيث تعد وظيفة تعويض المضرور عن الأضرار التي أصابته، نتيجة لخطاً

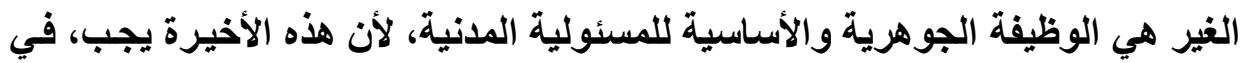

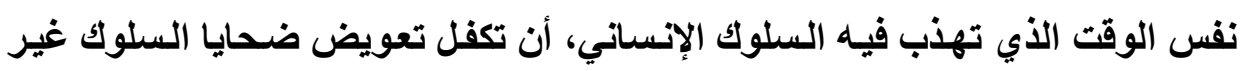

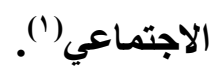

لذا جاءت المسئولية المدنية كي تحمي الحقى، أو المصلحة التي انصبت عليها

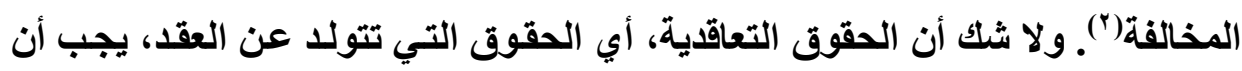

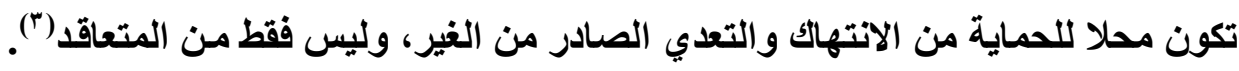

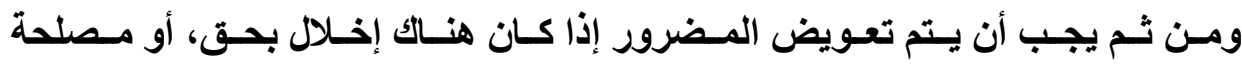

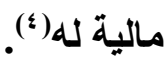

وإذا كان هناك مبدأ جوهري، في مجال العقود، وهو مبدأ سلطان الإرادة"(م)، إلا

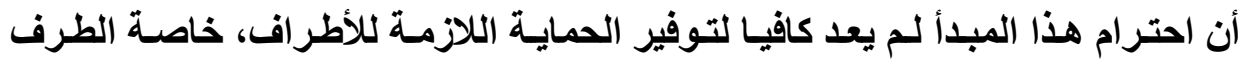
الضعيف، ولم يعد محققا لهم فرصة الحصول على التعويض المناسب عن الأضرار التي

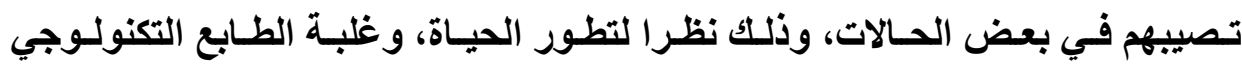
(1) محسن عبد الحميد البيه، حقيقة أزمة المسئولية المدنية ودور تأمين المسئولية، المرجع السابق،

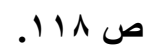
(汭 محسن عبد الحميد البيه، حقيقة أزمة المسئولية المدنية ودور تأمين المسئولية، المرجع السابق، . 1.0

(3) Clark A. Remington, Intentional interference with contract and the doctrine of efficient breach: Fine tuning the notion of the contract breacher as wrongdoer, Buffalo Law Review, Vol. 47, 1999, P. 654.

(؛) شريف الطباخ، التعويض عن الإخلال بالعقد، التطبيق العملي للمسئولية المدنية في ضوء القضاء

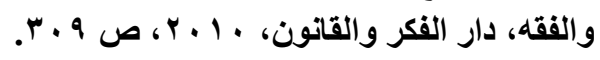

(•) محسن عبد الحميد البيه، حقيقة أزمة المسنولية المدنية ودور تأمين المسئولية، المرجع السابق،

$$
\text { ص +ك. }
$$


والتقني على وسائلها، مما أدى إلى زيادة فرص تحقق الضرر في فروض يصعب على إنى

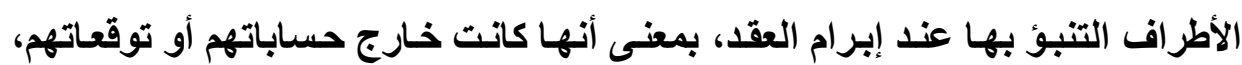

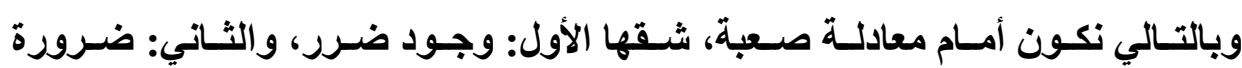

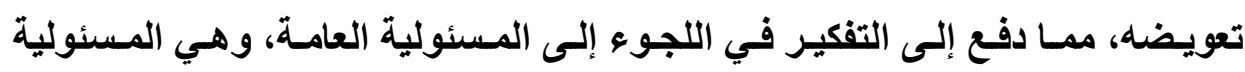

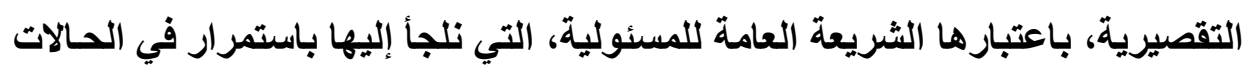

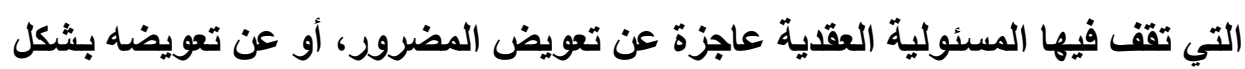
كاف) (1) (1)

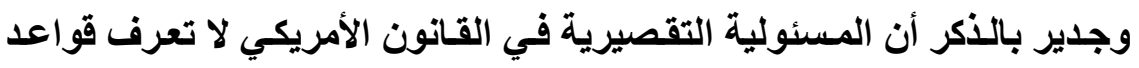

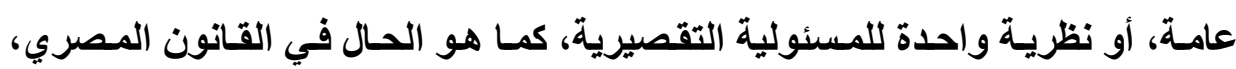

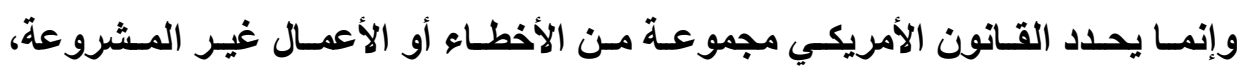

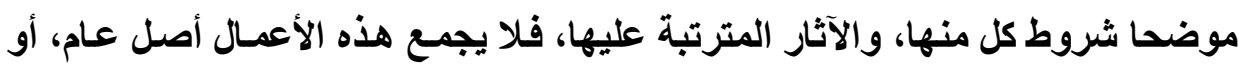

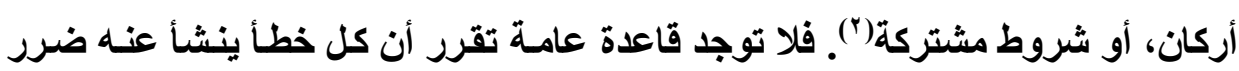
يوجب التعويض، وإنما هي أعمال معينة ترتب المسئولية("). ومن هنا ظهرت فكرة المسئولية التقصيرية عن التدخل في العلاقات التعاقية،ة

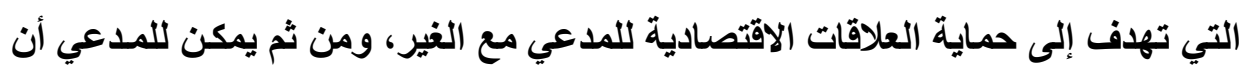

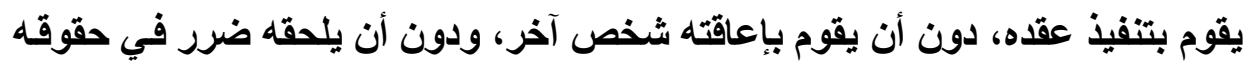

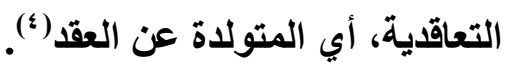

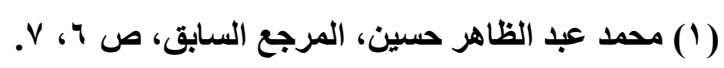

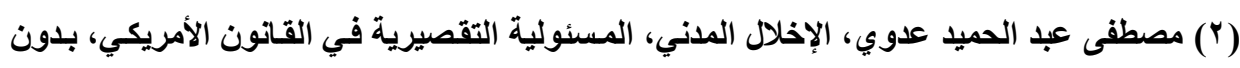

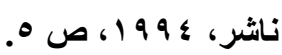

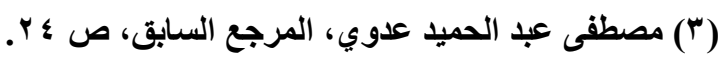

(4) Jeanette Andersson, Interference with contractual relations, Juridiska institutionen, Programmet for Juris Kandidatexamen, 1998, P. 7. 
وأصسبحت نظريـة المسئولية عـن التــخل التعسفي أو العمــي فـي العلاقـات

التعاقدية واحدة من أكثر نظريـات المسئولية التقصيرية تطورا في الولايـات المتحدة

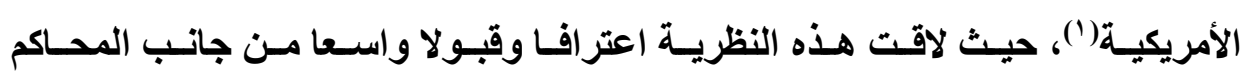

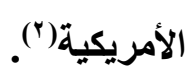

وتتمثل هذه الصورة الخطيرة، من صور المسئولية، في الفرض الذي يقوم فيه

شخص، وهو على علم بوجود عقد بين طرفين، بالتدخل في هذا العقد متعدا، بتحريض

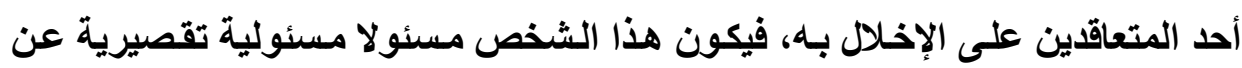

التدخل المتعدد في هذه العلاقة التعاقدية، وبالتـالي يلتزم بتعويض المتعاقد المضرور

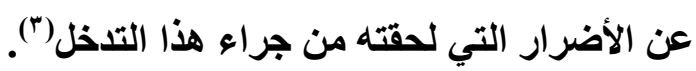

وهذا ما دفع البعض إلى تسمية هذه الصورة الخطيرة من صور المسئولية

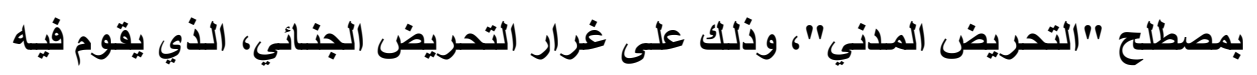

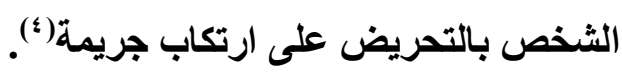

(1) Jerry C. Estes, Expanding horizons in the law of torts, Tortious interference, Drake Law Review, Vol. 23, January 1974, P. 341.

(2) Gary Myers, The differing treatment of efficiency and competition in Antitrust and Tortious interference law, Minnesota Law Review, Vol. 77: 1097, 1993, P. 1108.

(3) Barbara Tuttle Gamer, The agent's privilege to interfere intentionally with contractual relations: A reappraisal of California Law, California Western Law Review, Vol. 12, 1976, P. 475.

(4) Brand Lawless Cooper, Civil conspiracy and interference with contractual relations, Loyola Of Los Angeles Law Review, Vol. 8, 1975, P. 306. 
وأخيرا، على الرغم من أن القواعد التقليدية للمسئولية التقصيرية في القانون

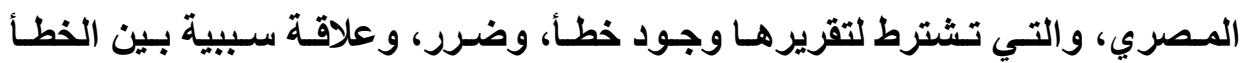

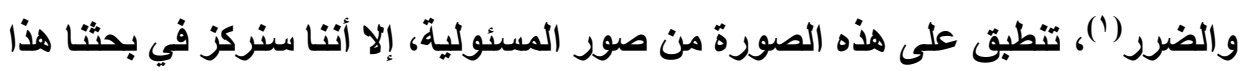

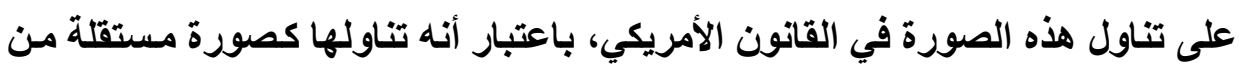

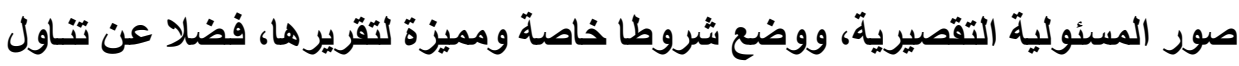
المحاكم الأمريكية العديد من القضايا المتعلقة بها. خطة الدراسة:

ويناء على ما تقدم، نرى تقسيم بحثنا هذا إلى فصلين، يسبقهما مبحث تمهيدي،

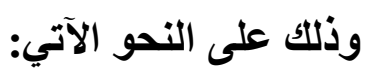

المبحث التههيدي: تطور فكرة المسئولية التقصيرية عن التـخل في العلاقات

$$
\text { التعاقدية. }
$$

الفصل الأول: ماهية المسئولية التقصيرية عن التدخل في العلاقات التعاقية

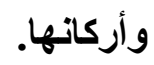

الفصل الثاني: جزاء المسئولية التقصيرية عن التدخل في العلاقات التعاقدية

$$
\text { وحالات الإعفاء منها. }
$$

(1) محسن عبد الحميد البيه، حقيقة أزمة المسئولية المدنية ودور تأمين المسئولية، المرجع السابق، 
د/ حسام الدين محمود حسن

العدد 77 (أغسطس Y.r/1) 


\section{المبحث التمهيدي \\ تطور فكرة المسئولية التقصيرية عن التدخل \\ في العلاقات التعاقدية}

تعد فكرة المسئولية عن التدخل التعسفي أو العمدي في العلاقات التعاقدية، أو

المصلحة الاقتصادية المحتملة ذات أصل قديم نسبيا'(') حيث يرجع أصل هذه المسئولية

إلى القانون الروماني، عندما كان يمكن لصاحب المنزل أن يرفع دعوى المسئولية ضد

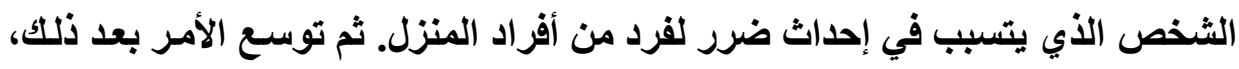

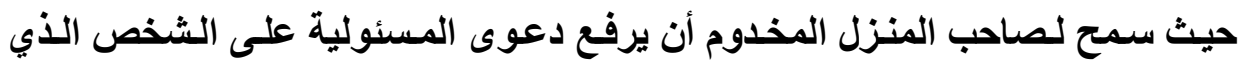
يصيب خادمه بضرر، مما أدى إلى فقدان صاحب المنزل المخدوم للخدمة التي كان يقوم

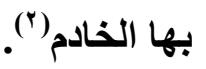

وفي القانون الإنجليزي، استمدت فكرة المسئولية عن التدخل في العلاقات

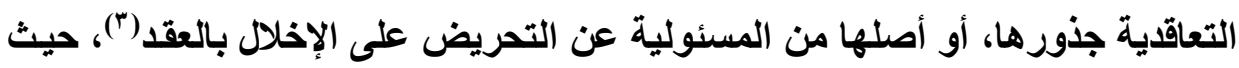

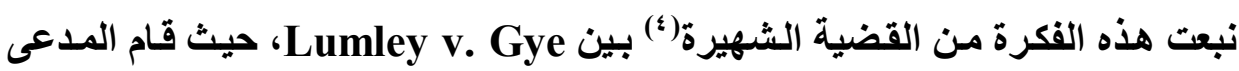

(1) W. Prosser, Law of torts, third edition, 1964, P. 973.

(2) Odette Woods, Tort law, Tortious interference with contract: The Arkansas supreme court clarifies who has the burden and what they have to prove, Mason v. Wal-Mart Stores, Inc., 333 Ark. 3, 969 S.W.2d 160 (1998), University of Arkansas at Little Rock Law Review, Spring, 1999, P. 3. Gary D. Wexler, Intentional interference with contract: Market efficiency and individual liberty considerations, Connecticut Law Review, Vol. 27:279, 1994, P. 284.

(3) Jeanette Andersson, previous reference, P. 7.

(4) Lumley v. Gye, 2 El. And Bl. 216, 118 Eng. Rep. 749 (1853). 
عليه بتحريض مغن على الإخلال بعقده، وعدم الغتـاء في مسرح المدعي، وذلكك عن طريق تقديم المدعى عليه لعرض أجر أكبر من الأجر المتفق عليه في العقد مع المدعي. وقد اعتبرت المحكمة أن التحريض على الإخلال بعقد قائم يرتب المسئولية القانونية،

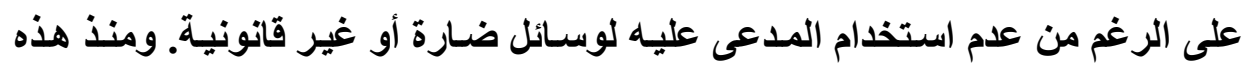

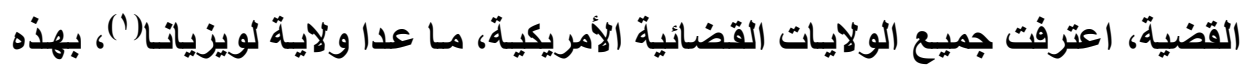
النظرية، وقررت مسئولية المدعي عليه عن التدخل في العلاقات التعاقيةل(؟).

وفي وقت لاحق، تم الفصل في عدة قضايا انجليزيـة متفرقة تشير إلى أنسه لا يمكن لشخص أن يتذخل في العلاقة التعاقدية لشخص آخر عن طريق استخدام وسـائل ضارة وغير مشروعة، مثل استخدام العنف، أو التهديد باستخدام العنف، أو الاحتبـال، أو التثهير (r).

ولقد أخذت المحاكم الأمريكية وقتا طويلا حتى اعترفت وتبنت نظريـة المسئولية

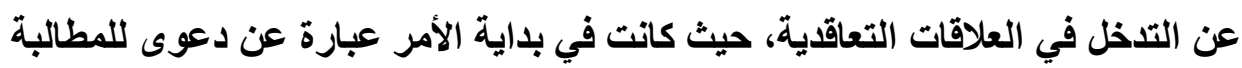
بالتعويض عن الأضرار ضد أي شخص يقوم بتحريض خادم المدعي لترك العمل عنده،

(1) Louisiana, the one remaining jurisdiction, previously refused to recognize the tort. Recently, however, the Supreme Court of Louisiana implied that, under limited circumstances, it would recognize tortious interference with contractual relations.

(2) James B. Sales, The tort of interference with contract: An argument for requiring a valid existing contract to restrain the use of tort law in circumventing contract law remedies, Texas Tech Law Review, Vol. 22: 123, 1991, P. 124. Gina M. Grothe, Interference with contract in the competitive marketplace, William Mitchell Law Review, Vol. 15, 1989, P. 457.

(3) Jerry C. Estes, previous reference, P. 341. 
ثم تظورت هذه النظرية تظورا ملحوظا، حيث توسعت المحاكم الأمريكية في حمايـة كل

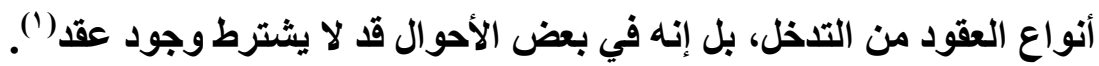

فعلى سبيل المثال، اعترفت ولاية ألاسكا منذ عام ^99 19 بالمسئولية عن التخخل

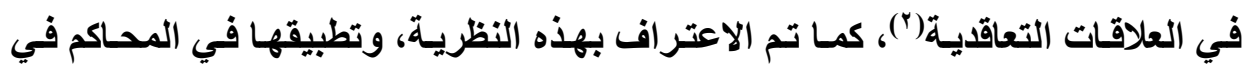
ولاية أيوا(")، ثم في وقت لاحق قبلت عدة محاكم نظريـة التدخل المتعمد في العلاقات التهات

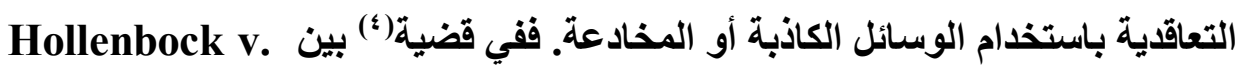
Ristine

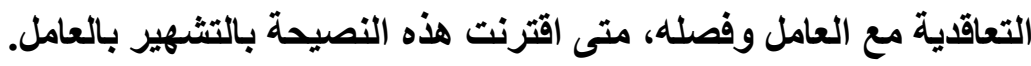
وفي وقت لاحق اعترفت وتبنت المحكمة العليا في ولايـة أيوا(0) صراحة نظريـة التخخل في المصلحة أو المزايا الاقتصادية المحتملة وثئة وباستقراء ما قدمنا من مراحل لتطور فكرة المسئولية عن التدخل في العلاقات

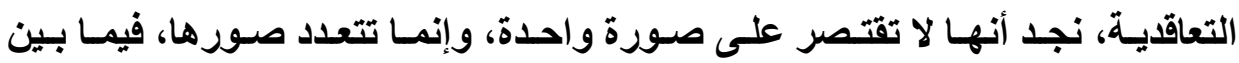

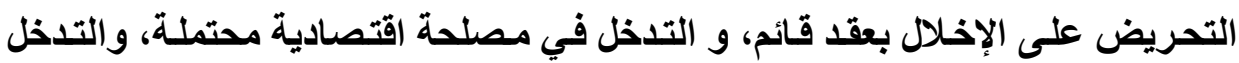
باستخدام وسائل غير مشروعة، ولا شك في أن ذلك يثير العديد من المشكلات القانونية

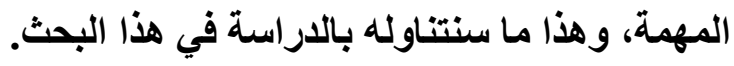

(1) Gina M. Grothe, previous reference, P. 454.

(2) Diane J. Klein, Treaties and domestic law after Medell'In v. Texas: Article: "Go west, Disappointed Heir": Tortious interference with expectation of inheritance- A survey with analysis of State approaches in the Pacific States, Lewis and Clark Law School Law Review, Spring, 2009, P. 13.

(3) Andrews v. Blakeslee, 12 Iowa 577 (1862).

(4) Hollenbock v. Ristine, 114 Iowa 358, 86 N. W. 377 (1901), the court held that one cannot advise an employer to discharge an employee when the advice is accompanied by libelous charges.

(5) Clark v. Figge, 181 N.W. 2d. 211 (Iowa 1970). 
د/ حسام الدين محمود حسن

العدد 77 (أغسطس Y. (1)

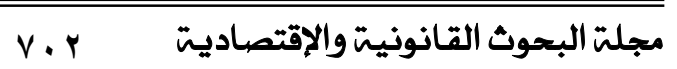




\title{
الفصل الأول \\ هاهية المسئولية التقصيرية عن التدخل في \\ العلاقات التعاقدية وأركانها
}

\begin{abstract}
تمهيد وتقسيم:
تعد المسئولية التقصيرية عن التدخل في العلاقـات التعاقدية صسورة متميزة

مـن صـور المسئولية، سـواء مـن حيـث مـضمونها، أو أساسـهـا، أو صـور الإخـلال فيها، أو أركانها وعناصرها. لذا يتعين علينا، قبل البدء في بيـان الأركان أو العناصر

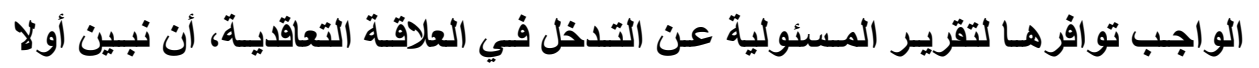
ماهيتها. وبناء على ما تقدم، نرى تقسيم هذا الفصل إلى مبحثين، وذلك على النحو الآتي: المبحث الأول: ماهية المسئولية التقصيرية عن التخخل في العلاقات التعاقدية. المبـــث الثـاني: أركسان المسئولية التقصيرية عـن التــلـ في العلاقـات التعاقدية.
\end{abstract}




\section{المبحث الأول \\ هاهية المسئولية التقصيرية عن التدخل في \\ العلاقات التعاقدية}

\section{تمهيد وتقسيم:}

إن بحثـا ودراستتنا عن ماهية المسئولية التقصيرية عن التـخل في العلاقات

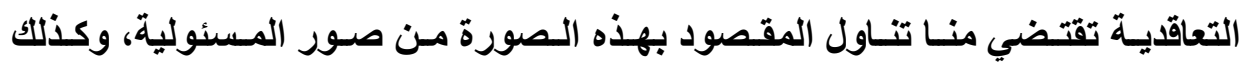

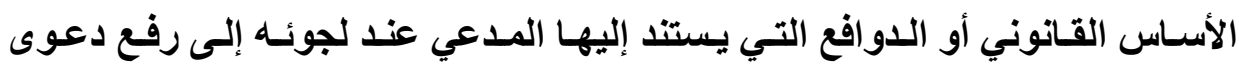
المسئولية التقصيرية على الغير، المتدخل في العلاقة التعاقدية، والذي ترتب على تلخله الإخلال بالعلاقة التعاقدية، بجانب الحق في رفع دعوى المسئولية العقدية على المتعاقد الأي أخل بالتزامه تجاهه. وينـاء على مـا تقدم، نرى تقسيم هذا المبحث إلى مطلبين، وذلك على النحو

المطاسب الأول: المقصود بالمسئولية التقصيرية عـن التــلـ فـي العلاقـات

$$
\text { التعاقدية. }
$$

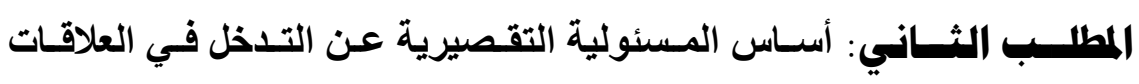

التعاقدية. 


\section{المطاب الأول \\ الاقصود بالمسئولية التقصيرية عن التدخل في \\ العلاقات التعاقدية}

إن الإخلال المدني، أو المسئولية التقصيرية، بصفة عامة، تفترض وجود تجاوز

شخصي، أو سلوك غير مكترث، أو غير مقبول اجتماعيا، ترتب عليه ضرر خـاص،

ويكون للمضرور الحق في المطالبة بالتعويض، بطريق الدعوى المدنية(')

إذن فالمسسئولية التقـصيرية هـي "مسساولة المخطسئ عمــا ارتكبـه مسن خطـأ

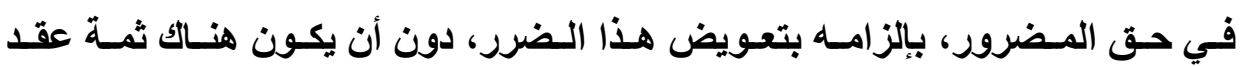
بينهما"(")

ولقد عرفت بعض المحاكم الأمريكية المسئولية التقصيرية عن التدخل التعسفي

في العلاقات التعاقديـة على أنـه التدخل المقصود أو المتعمد، وغير المبرر في العقد

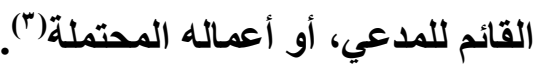

ويعني هذا التعريف أن مسألة تبريـر التـدل في العلاقة التعاقديـة هـي دفـاع

إيجابي، وأن الأمر يرجع إلى المتدخل لتبرير فعله حتى يتم إعفـاؤه من المسئولية عن أنس

$$
\begin{aligned}
& \text { (1) مصطفى عبد الحميد عدوي، المرجع السابق، ص بّا. }
\end{aligned}
$$

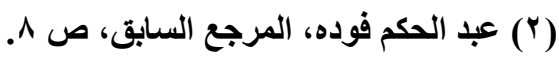

(3) Some courts have defined tortious interference as an intentional interference, without justification, with plaintiff's known contracts or business prospects. Neff v. World Publishing Co., 349 F.2d 235 (8th Cir. 1965); McDonough v. Kellogg, 295 F. Supp. 594 (W.D. Va. 1969); Cady v. Hartford Accident \& Indemn. Co., 439 S.W.2d 483 (Mo. 1969). 
التخل في علاقة المدعي التعاقدية مـع الغير، وأن على المدعي عبء توقع المبررات المزعومة، وضحدها منذ البداية(').

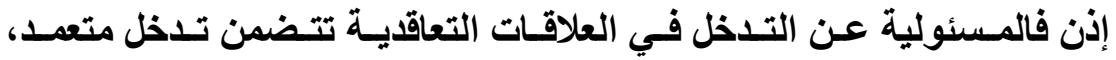

وغير مشروع، في الحقوق التعاقديـة للغير(؟). ويجب أن يترتب على هذا التـدخل

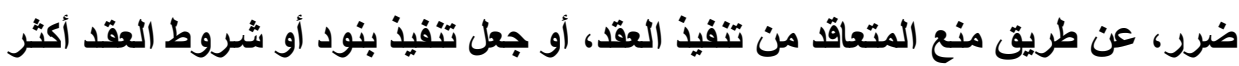

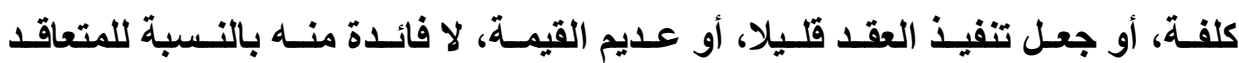

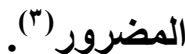

وباستقراء ما سبق نجد أنه تثقرر المسئولية عن التدخل في العلاقة التعاقدية

عندما يتعمد المدعى عليه التذخل في تنفيذ عقد بين طرفين، عن طريق تحريض أحد المتعاقدين على الإخلال بالعقد، أو التسبب في عدم مقدرته على التتفيذ(؛).

(1) Jerry C. Estes, previous reference, P. 344.

(2) Sandra S. Baron, Hilary Lane, and David A. Schulz, Tortious interference: The limits of Common Law liability for Newsgathering, William and Mary Bill of Rights Journal, Vol. 4:3, 1996, P. 1029.

(3) The tort of interference with contract involves intentional and improper interference with another's contract rights. The interference must proximately cause some type of harm by, for example, preventing performance, making it more costly to carry out the terms of the contract, or making performance less valuable. Gary Myers, previous reference, $P .1107$.

(4) Alex B. Long, Attorney liability for tortious interference: Interference with contractual relations or interference with the practice of law?, Georgetown Journal Of Legal Ethics, Spring 2005, P. 3. Dan B. Dobbs, Tortious interference with contractual relationships, Arkansas Law Review, Vol. 34: 335, 1980, P. 335. 


\section{المطلب الثاني \\ أساس المسئولية التقصيرية عن التدخل في \\ العلاقات التعاقدية}

تتعدد الأسباب، أو الأهداف، أو الأسس وراء تقرير المسئولية التقصيرية عن

التدخل في العلاقات التعاقدية، ونبين ذلك على نحو من التفصيل الآتي:

ا - هماية استقرار العلاقات التعاقدية:

يرجع السبب أو الأساس الأول في إنشاء هذا النوع من المسئولية إلى الرغبة

في المحافظة على استقرار العقود(')، ويتم ذلك من خلال حماية حق أو مصلحة المتعاقد في أن يتحقق تتفيذ المتعاقد الآخر لالتزامـه المتولد عن العقد. وبمعنى آخر، تشجيع تنفيذ العقود، عن طريق منع تدخل طرف ثالث في هذا التنفيذ(؟).

إذن فنظريـة المسئولية عن التـخل في العلاقـات التعاقديـة تهـدف إلى حمايـة

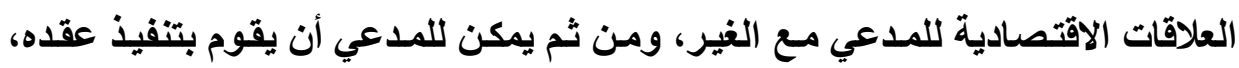
دون أن يقوم بإعاقته شـخص آخر، ودون أن يلحقـه ضـر في حقوقـه التعاقديـة، أي

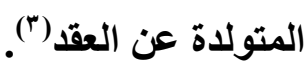

(1) Steven W. Feldman, Tortious interference with contract in Tennessee: A practitioner's guide, The University of Memphis Law Review, Winter, 2001, P. 1.

(2) Gary D. Wexler, previous reference, P. 301.

(3) Jeanette Andersson, previous reference, P. 7. 


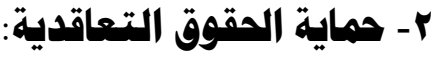

كما قدمنا من قبل، لقد نشأت المسئولية المدنية كي تحمي الحق، أو المصلحة التي انصبت عليها المخالفة('). ولا شك أن الحقوق التعاقية، أي الحقوق التي تتولد عن العقد، يجب أن تكون محلا للحماية من الانتهايك والتعدي الصدادر من الغير، وليس

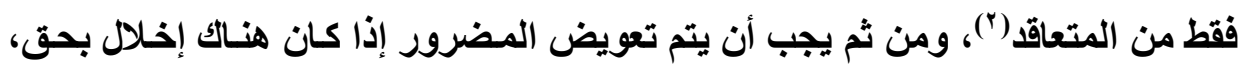

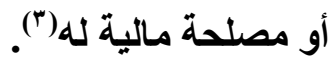

فكثير من المحاكم الأمريكية تبرر فرض المسئولية التقصيرية عن التدخل في العلاقات التعاقية على أساس أن الحقوق التعاقدية تعد بمثابة حقوق ملكية للمتعاقدين، لا يحق لطرف ثالث أن ينتهكها، أو يتعدى عليها(؛)، بل تطورت المسئولية عن التدخل في العلاقة التعاقدية بحيث أصبحث تثمل التدخل لوقف، أو عرقلة الحصول على حقوق تعاقدية، أو مصلحة اقتصادية محتملة.

فإذا ترتب على تدخل المدعى عليه عدم قدرة المدعي على الدخول في علاقة

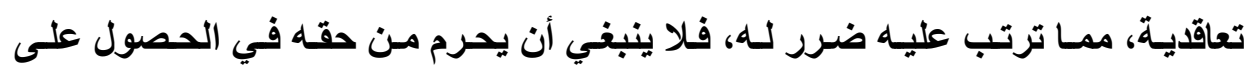
تعويض عن هذا الضرر(م).

(1) محسن عبد الحميد البيه، حقيقة أزمة المسئولية المدنية ودور تأمين المسئولية، المرجع السابق،

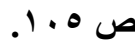

(2) Clark A. Remington, previous reference, P. 654.

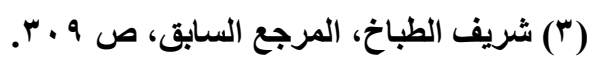

(4) Many courts, justify the imposition of interference liability on the basis that parties to a contract have property rights in the contract. Gary D. Wexler, previous reference, P. 302.

(5) Jerry C. Estes, previous reference, P. 344. 


\section{r- تصور المسئولية العقدية عن تعويض المتعاقد المضرور:}

بدايـة نـود أن نشير إلى أن المقصود بالخطـأ أو الإخـلال العقدي هو عدم قيـام المدين بتفيذ التزامه طوعا واختيارا. فالمسئولية العقدية هي جزاء عدم تنفيذ العقد، وقيامها يفترض وجود عقد صحيح، واجب التنفيذ، ولم يقم المدين بهذا التنفيذ. ويترتب على تقرير المسئولية العقدية تعويض الدائن عن الأضرار التي أصـابته من جراء عدم لفم

$$
\text { تنفيذ المدين لالتزامه (') }
$$

وجدير بالذكر أن المسئولية التقصيرية للشخص المتدخل في العلاقة التعاقدية مستقلة عن المسئولية العقديـة للمتعاقد الذي أخل بالتزامسه التعاقدي تجـاه المتعاقد المضرور. ومن ثم يسأل الشخص الذي حرض المتعاقد على الإخلال بالعقد مسئولية تقصيرية، بصرف النظر عن المسئولية العقدية لهذا المتعاقد. وبالتـالي يحق للمتعاقد المضرور أن يرجع على الطرفين، الأول وهو الشخص المتدخل في العلاقة التعاقدية، على أساس المسئولية التقصيرية، والثاني وهو المتعاقد المخل بالتزامه التعاقدي، على الثي أسناس المسئولية العقدية(؟).

ولا شـك في أن تضامن المـينين يعد مـن أهم ضـمانـات الـائن، التـي توفر لـه حماية لحقه. فبفضل تضامن المدينين المتعددين يتمكن اللائن من تجنب خطر إعسار أحدهم، بالحصول على كامـل حقـه مـن مـدين آخر منهم، كمـا يتجنب الوفـاء الجزئسي

$$
\text { (1) شريف الطباخ، المرجع السابق، ص } 9 \text { ـ r. }
$$

(2) Fred S. McChesney, Tortious interference with contract versus "Efficient" Breach: Theory and Empirical Evidence, The University of Chicago, The Journal of Legal Studies, January 1999, P. 16.

(T) محسن عبد الحميد البيه، التضامن والتضامم في قضاء محكمة الاستنـاف العليا الكويتية مقارنـا

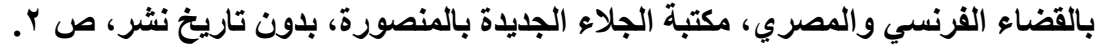


ويفترض التضامن بين المدينين وجود نص قانوني، أو اتفاق يقرر تضامنهم،

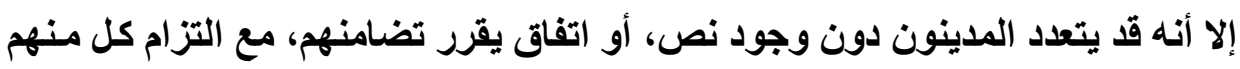
أمام الدائن بكل الدين، وتكون ديونهم متميزة عن بعضها البعض، لتعدد مصادرها، ففي

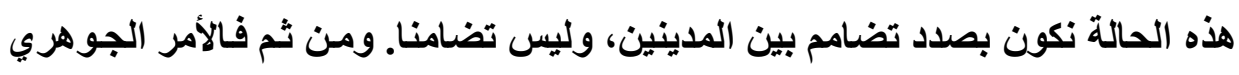

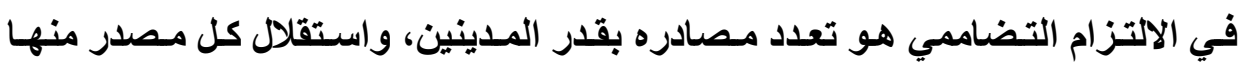

$$
\text { بالنسبة إلى كل مدين (1). }
$$

وعلى ذلك فعندما يسهم عدة أشخاص في إحداث الضرر للغير، فإنهم يلتزمون جميعا على وجه التضامم، بحيث يمكن للمضرور أن يرجع على أي منهم بكل التعويض.

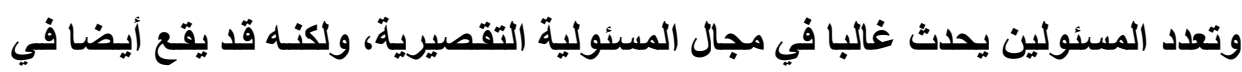
مجـال المسئولية العقديـة، وأخيـرا يمكن أن يكـون البعض مسئولان عقديا، والآخـر

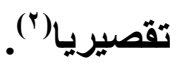

فعندما تتعدد مصادر الالتزام بتعويض المضرور، مثل التزام أحدهم عقديا،

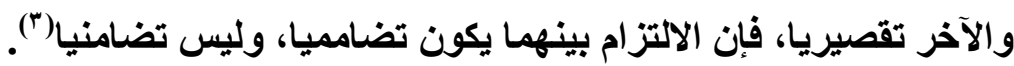

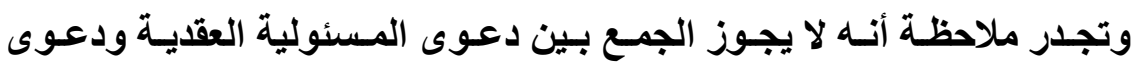

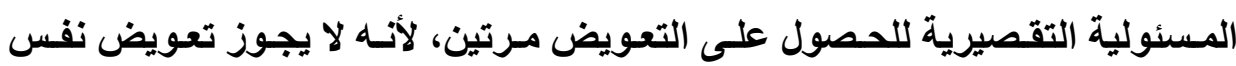

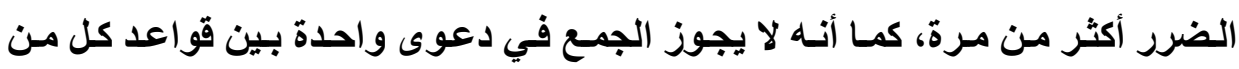

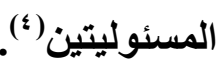

(1) محسن عبد الحميد البيه، التضامن والتضامم في قضاء محكمة الاستثناف العليا الكويتية مقارنـا بالقضاء الفرنسي والمصري، المرجع السابق، ص ع ؛ ، ه.

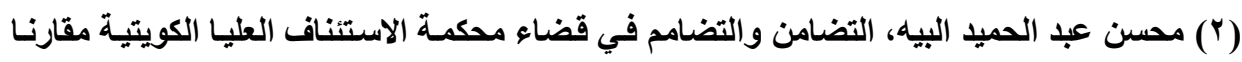

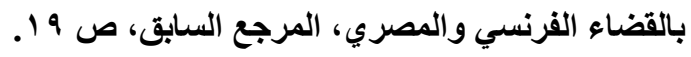

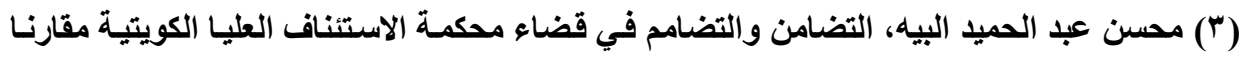

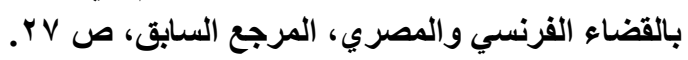

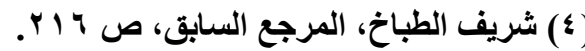

VI. 
ونود أن نشير إلى أنـه تختلف المسئولية العقدية عن المسئولية التقصيرية

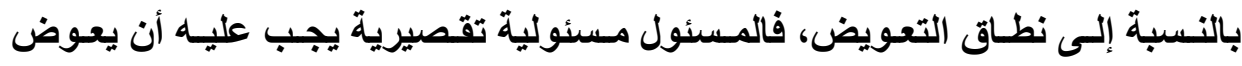

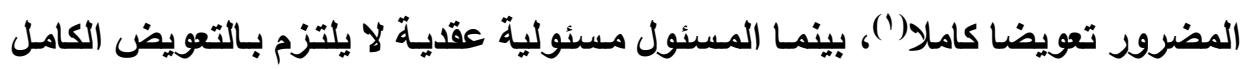
للمضرور في كل الحالات، فعندما لا يكون هناك غش، أو خطأ جسيم من جانب المدين، فِان التعويض لا يثمل إلا الأضرار المتوقعة فقط لهان.

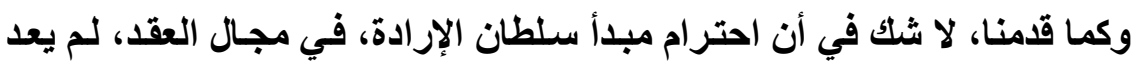
كافيا لتوفير الحماية اللازمة للأطراف، خاصة الطرف الضعيف، ولم يعد محققا لهم فرصة الحصول على التعويض المناسب للأضرار التي تصيبهم في بعض الحسالات،

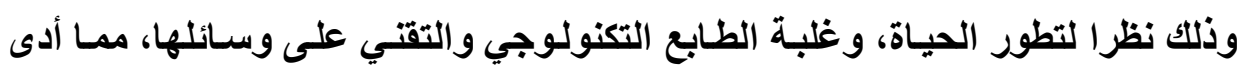
إلى زيادة فرص تحقق الضرر، في فروض يصعب على الأطراف التنبؤ بها عند إبرام

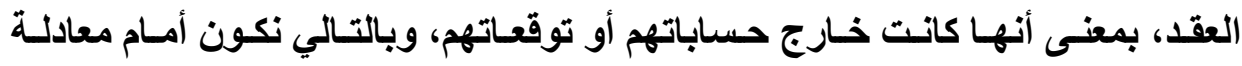

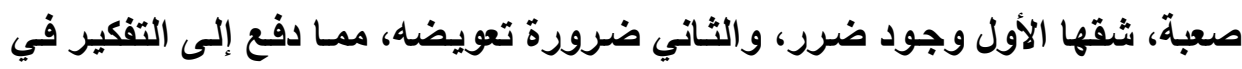

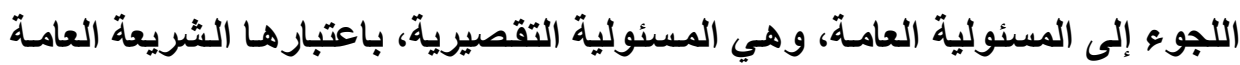

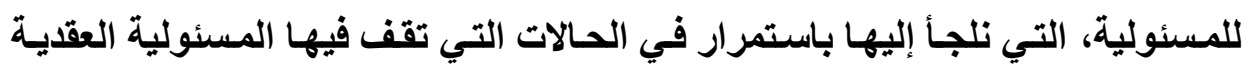
عاجزة عن تعويض المضرور، أو عن تعويضه بثكل كاف("). وبالتـالي يجوز للمضرور أن يرفع دعوى المسئولية التقصيرية بعد فشل دعوى المسئولية العقدية في حصوله على التعويض، أو إذا لم ينجح في الحكم لـه

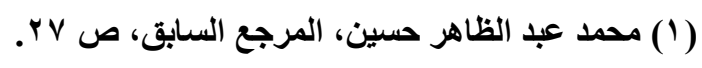

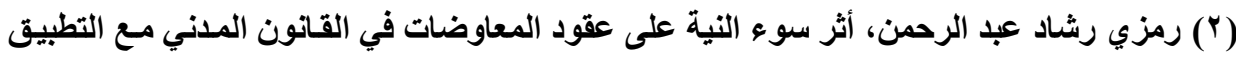

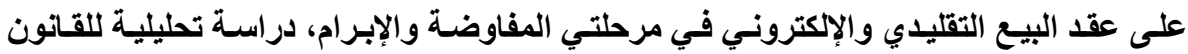

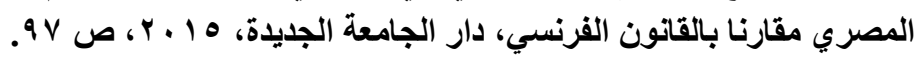

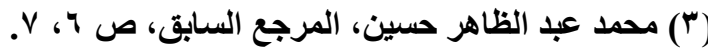


بتعويض مناسب عن كافـة الأضرار التي لحقت بـه. فللمـضرور اللجوء إلى دعوى المسئولية التقصيرية، للمطالبة بالتعويض عن الأضرار غير المتوقعة، والتي لم تكن

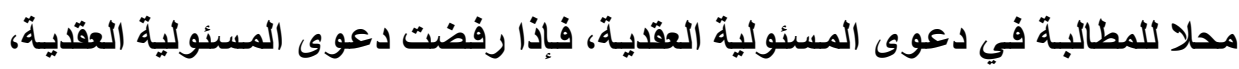
فِإن من حق المضرور أن يرفع دعوى المسئولية التقصيرية، وذلك نظرا لاختلاف أساس كل من اللدعويين، فالأولى تقوم على أسـاس وجود إخـلال بـالتزام تعاقدي، أمسا الثانيـة تقوم على أسـاس إخـلال بـالتزام قـانوني، حتى ولو كـان المضرور واحدا في

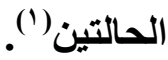
لكل ما تقام، يتمثل الأساس الثالث لفرض المسئولية التقصيرية عن التدخل في العلاقات التعاقدية في أن التعويض الذي يحكم به في دعوى المسئولية العقدية، المقامة على المتعاقد الذي أخل بالتزامه، قد لا يكفي لجبر ضرر المتعاقد المضرور. فهو قد لا يكفي لحصول المتعاقد المضرور على الربح الذي كان سيجنيه من الصفقة محل التعاقد، لاسيما إذا كان المتعاقد المخل بالعقد معسرا، كما لا يشمل التعويض مصاريف التقاضي

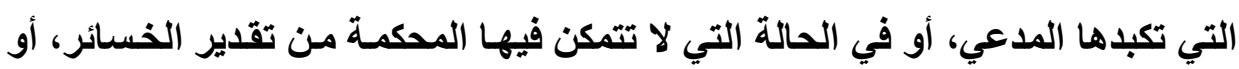
الأضرار المتوقعة بدقة)(؟)

فالتعويض المبني على المسئولية العقدية يفتقد إلى الفعالية التي تجبر المتعاقد على احترام التزاماته التعاقدية، طالما أن معرفة الجزاء وتوقعه مسبقا يدفعه إلى التحلل

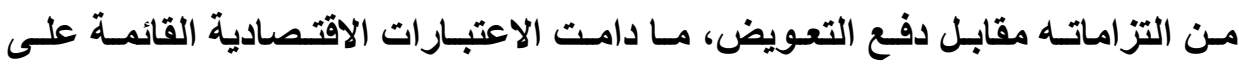
حسابات الكسب والخسارة، تجعل له مصلحة في ذلك، تجاوز تلكك التي يمكنه الحصول

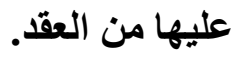

(1) محمد عبد الظاهر حسين، المرجع السابق، ص ؛ ؟. (2) Gary D. Wexler, previous reference, P. 305. 
وتطبيقا لذلك، قد يتعاقد متجر مع إحدى شركات الأثاث على تصنيع عدد معين

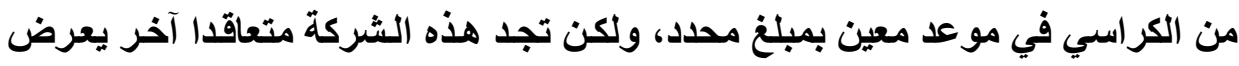

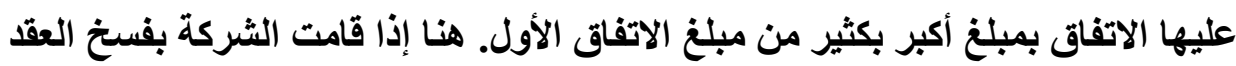

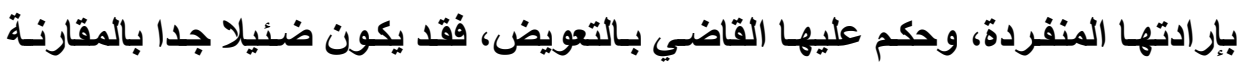

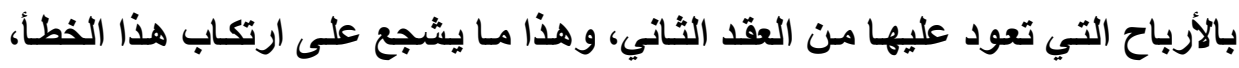
والذي يطلق عليه البعض الخطأ المكسب أو المربح' (1). ويعرف البعض الخطأ المكسب بأنها: "خطأ، من طبيعة عقدية أو تقصيرية،

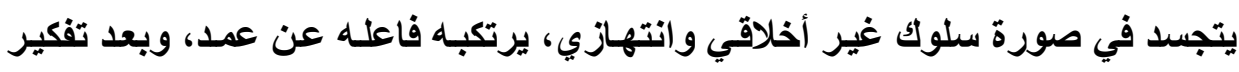

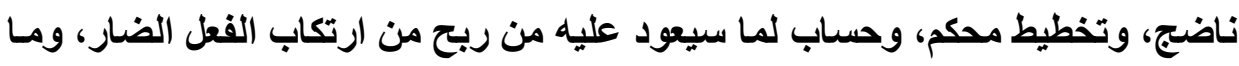

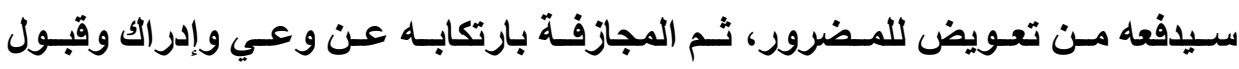

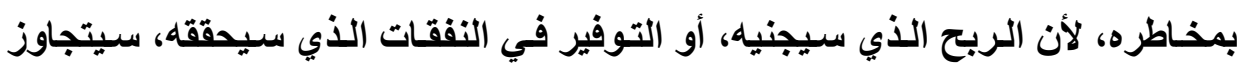
بكثير التعويض الذي سيحم عليه به"(").

وعلى ذلك فالخطأ المكسب يتميز بعنصرين أساسيين، هما: الخطأ الذي يرتكبه

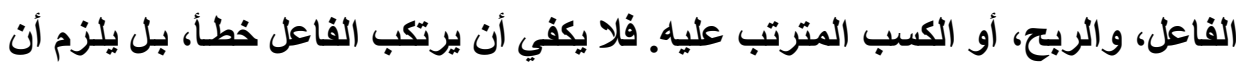

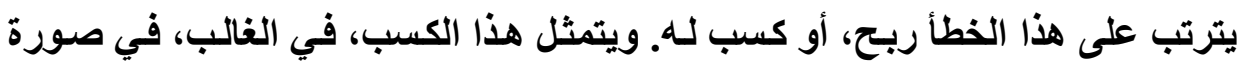

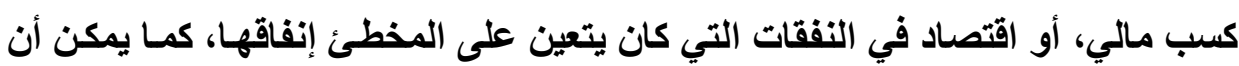

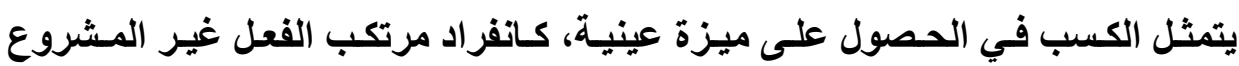
بالسوق، بعد إزاحة أو تجنيب منافس لله أو أكثر ("). 


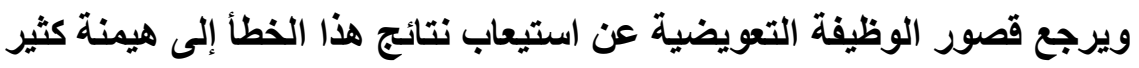

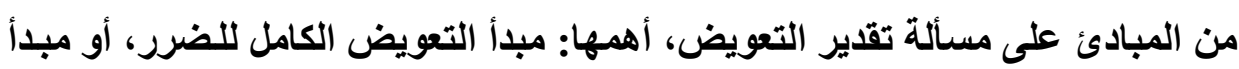

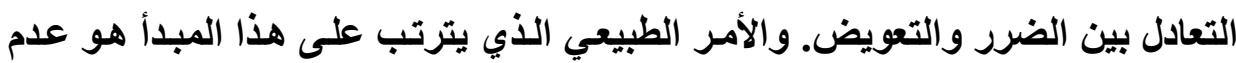
الأخذ في الاعتبار الكسب، أو الربح الذي عاد على مرتكب الفعل غير المشروع. ومن ثم

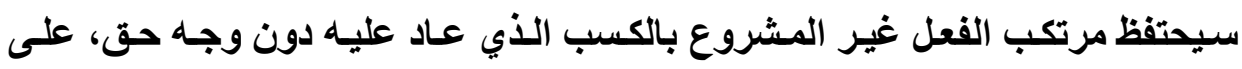

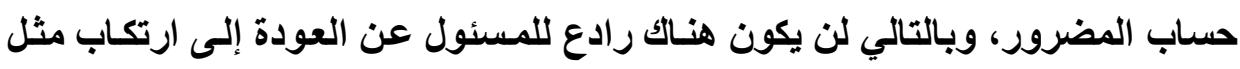

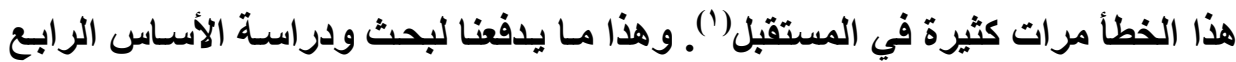
للمسئولية، وهو إثراء المدعى عليه غير في المشروع.

ع- الإثراء غير المشروع:

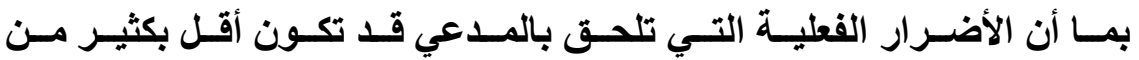

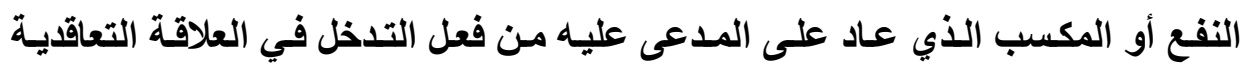

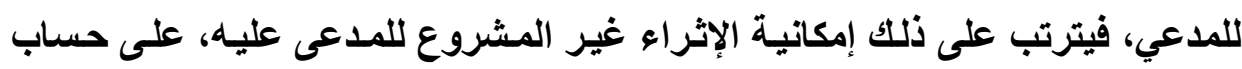

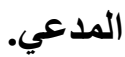

ومن ثم يستند الإثراء غير المشروع إلى فكرة أن المدعى عليه قد حصل على المّل

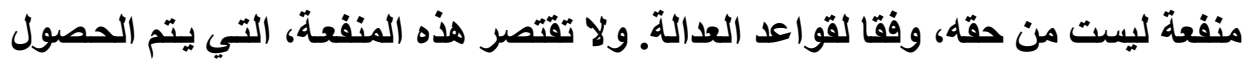

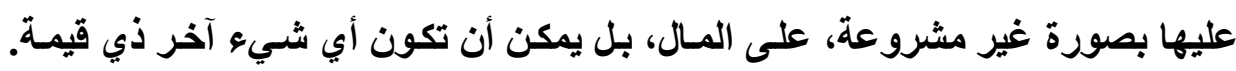

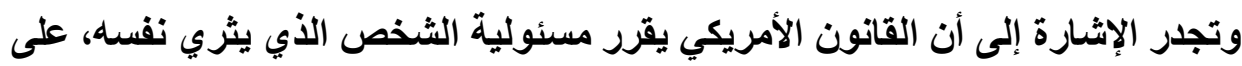

نحو غير عادل، على حساب آخر (†).

(1) عبد الهادي فوزي العوضي، المرجع السابق، ص • ^.

(2) Jerry C. Estes, previous reference, P. 355. 
ويبدو أن استخدام الإثراء غير المشروع، كأسساس لتعويض خسارة المـدعي

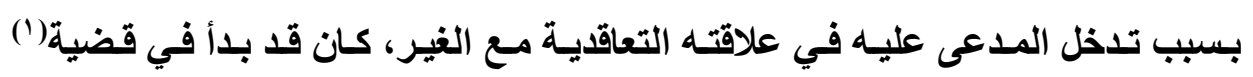
Federal Sugar Refining v. United States Equalization Board Inc.

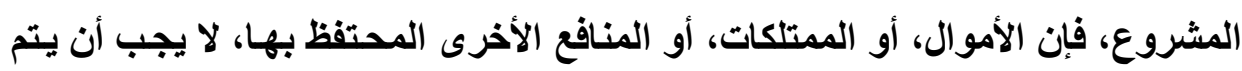

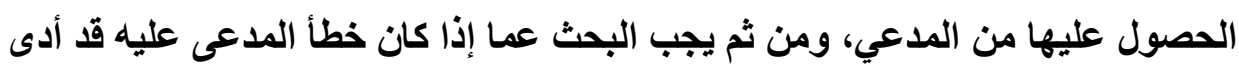

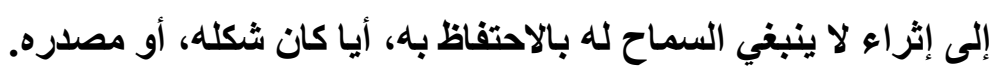
وجدير بالذكر أن مبدأ الإثراء غير العادل مرن للغاية، ويمكن أن يمتد ليشمل أي

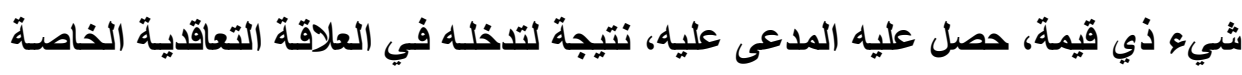

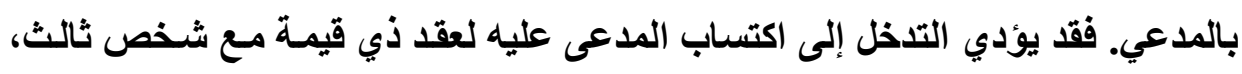

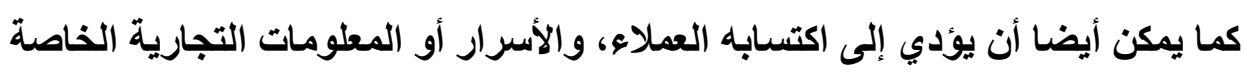

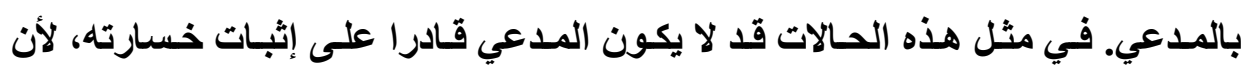

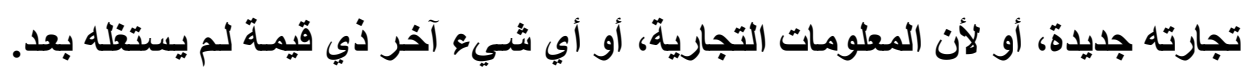

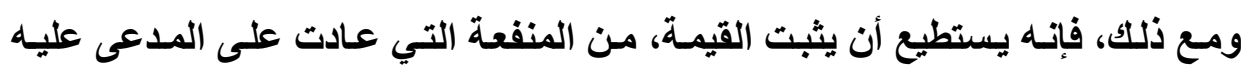
بموجب الإثراء غير المشروع.

وينطبق نفس الأمسر على العلاقـات أو الفـرص التجاريـة المستقبلية المتاحـة، في حالـة قيـام المـــى عليـه بالاسـتيلاء على علاقـات، أو فرص تجاريـة مـن خـلال

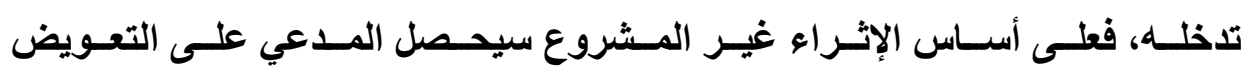

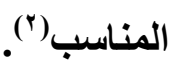

(1) Federal Sugar Refining v. United States Equalization Board Inc., 268 F. 575 (S.D.N.Y. 1920).

(2) Jerry C. Estes, previous reference, P. 356. 


\section{الامطاب الثاني \\ التدخل المتعمدد في العلاقة التعاقدية \\ (التعدي على المسلمة المصمية)}

عرف البعض الخطأ العمدي بأنـه: "السلوك الإرادي لشخص مـا، تجـاه شخص

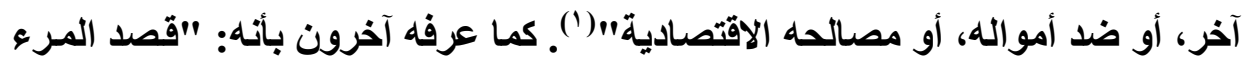

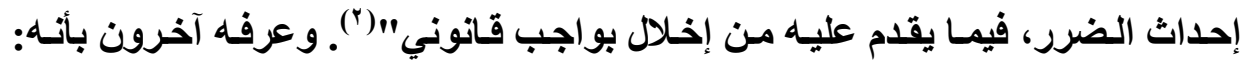
"الإخلال بواجب قانوني، مقترن بقصد الإضرار بالغير، أي هو اتجاه الإرادة إلى إحداث

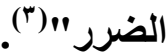

وعلى ذلك فيجب أن يكون الخطأ إراديا، أي أن يكون ناتجا عن نشاط إرادي، لا

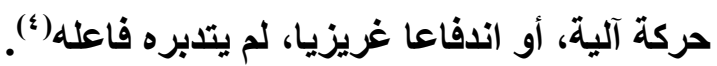
ولا شكك أن إدراك الفعل، أو العلم به، يعد عنصرا أساسيا ولازما لوصف السلوك بأنه خاطئ. فيجب أن يكون مرتكبه عالما بخطورة النتائج التي تترتب على ما يفعله(ْ). إذن يشترط لقيام الخطأ العمدي توافر عنصرين، العنصر المسادي: ويتمثل في الإخلال بواجب، أيا كان مصدره، وأيا كـان شكله، ويلزم فيه أن يكون إراديـا ومتعددا، وليس ناتجا عن مجرد الغفلة، أو السهو، وهو ما يعني ضرورة توافر الإدراك والتمييز

$$
\begin{aligned}
& \text { (1) مصطفى عبد الحميد عدوي، المرجع السابق، ص V V؛. }
\end{aligned}
$$

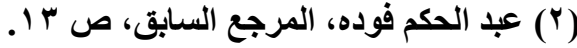

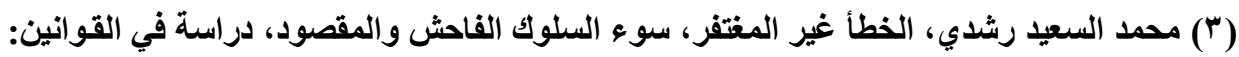

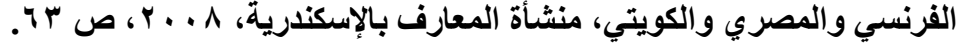

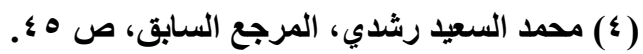

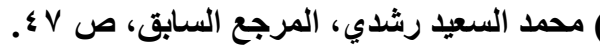


لاى الفاعل، ليس فقط بالفعل الذي يقوم بـه، ولكن أيضا بنتائجها الضارة بـالغير. كمـا يشترط في الإخـلال بالواجب الذي يرتكبـه الفاعل أن يكون غير مشروع، فـإذا كـان الإخلال مشروعا، فلا يعد مرتكب الفعل قد أخطأ، حتى ولو تعد الإضرار بالغير، كما هو يو الحال في المنافسة المشروعة.

ويتمثل العنصر الثاني للخطـأ العمدي في اتجـاه قصد مرتكبه إلى الإضـرار بالغير. فقد يتعد شخص ارتكاب فعل، ولكن لا يقصد من ورائها إحداث ضرر بـالغير. ويكفي توافر هذا القصد لاى مرتكب الفعل، حتى ولو لم يكن هذا هو هدفه الوحيد من

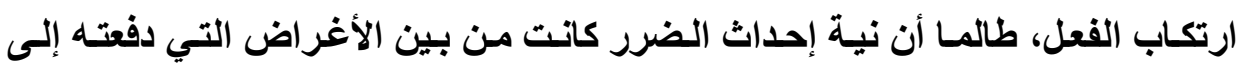

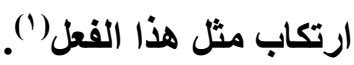

ولاثك أن التدخل في العلاقة التعاقدية هو خطأ متعمد من جانب المدعى عليه. أما الإهمال، الذي يترتب عليه تلدخل في العلاقة التعاقدية للغير، لا يعتبر أساسـا كافيا لرفع دعوى المسئولية عن التدخل في العلاقة التعاقدية(؟).

لذا فيتعين دائما أن يثبت المدعي أن المتدخل قد تعدد إلحاق الضرر بـه نتيجة لتلخله، فمثل هذا التعمد هو مـا يثبت سوع نية المدعى عليه، المتطلب توافرهـا لقيام مسئوليته عن التدخل في العلاقة التعاقدية للمدعي.

فالدافع لاى المدعى عليه يمثل المعيـار الحاسم في تحديد وتقرير المسئولية. بيد أنه من الضروري، حتى تثقرر المسئولية عن التدخل في العلاقة التعاقدية، إثبات

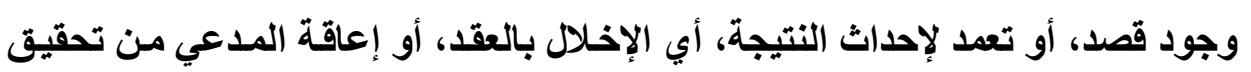

$$
\text { (1) عبد الهادي فوزي العوضي، المرجع السابق، ص • r، آس. }
$$

(2) Peter Edmundson, Sidestepping limited liability in corporate groups using the tort of interference with contract, Melbourne University Law Review Association, Inc., April 2006, P. 6. 
مصالح اقتصادية محتملة. وبعبارة أخرى، يجب أن يثبت على الأقل أن المدعى عليه كان على علم بمصالح المدعي، وتدخل عن عمد في هذه المصالح (') .

ولاثكك أن قصد الإضرار بالغير هو أبشع صور سوء النية، وأثند حالاته(").

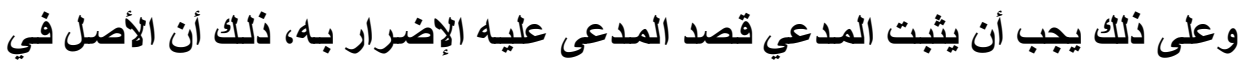

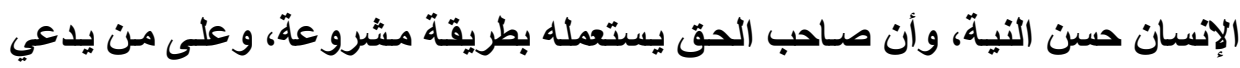

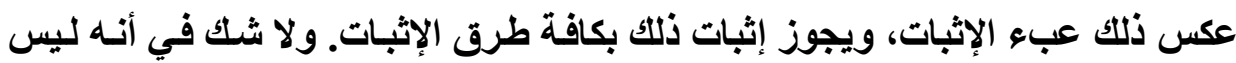
بالأمر اليسير إثبات قصد الإضرار بالغير، نظرا لكونه أمرا ذاتيا، أو شخصيا يرجع إلى التى

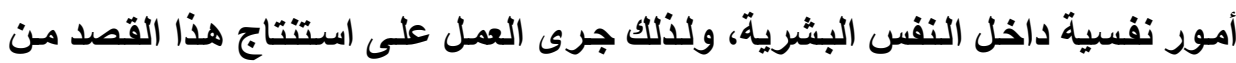
انعام مصلحة صاحب الحق، أو تفاهته(").

وبناء على مـا تقدم، إذا تسبب شخص متعمدا في قيام شخص آخر بـالإخلال بالعقد، فإنه يكون مسئولا عن تعويض المتعاقد المضرور( (4)، إذ يشترط حتى تنشئ

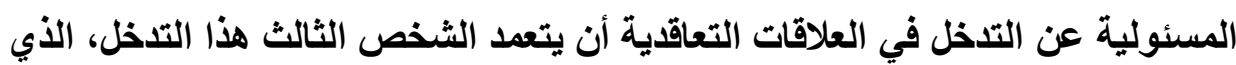
ينتج عنه الإخلال بالعقد، وبالتالي الإضرار بالمداعي المتعاقد، ويتمثل ذلك في الحالية

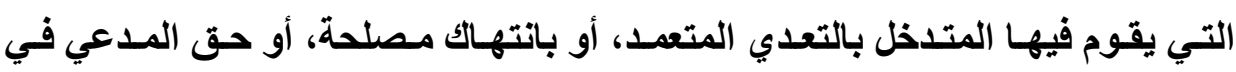

بيد أنسه يلاحظ في كثير مـن المحساكم أنها لم تكتف بفكرة أن مجرد التـخل

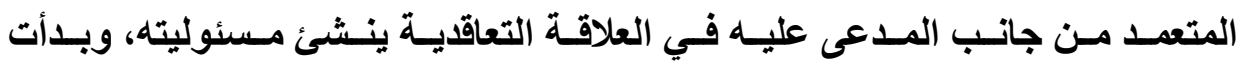

(1) Jerry C. Estes, previous reference, P. 346.

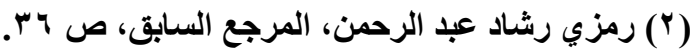

$$
\begin{aligned}
& \text { ("r) رمزي رشاد عبد الرحمن، المرجع السابق، ص } 9 \text { بـ. }
\end{aligned}
$$

(4) Clark A. Remington, previous reference, P. 648.

(5) Charles E. Carpenter, previous reference, P. 734. 


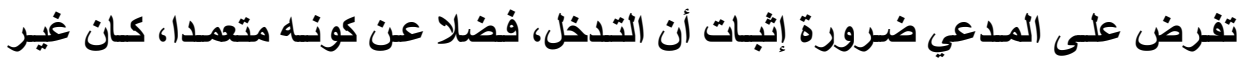

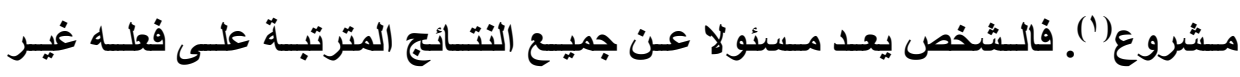

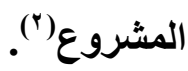

ويلتزم المدعي بإثبات إخلال المدعى عليه بواجبه، وعدم بذله العناية المعقولة،

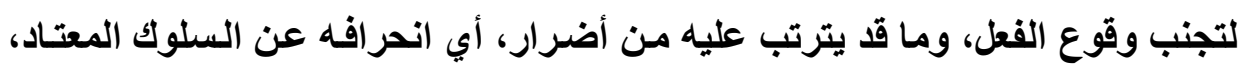

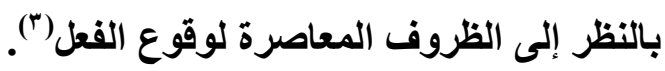
وقد يقوم الثخص بفعل معين لا يقصد منه تحريض المتعاقد ودفعه إلى الإخلال

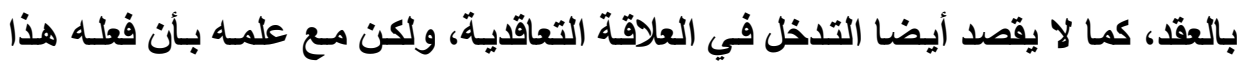

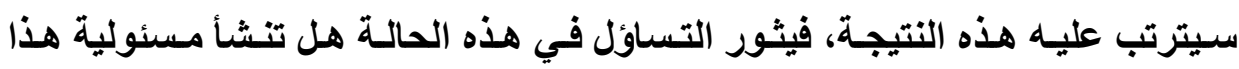

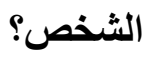

لا يوجد شكك بأن التذخل في العلاقة التعاقدية يجب أن يكون متعمدا، حتى تنشأ

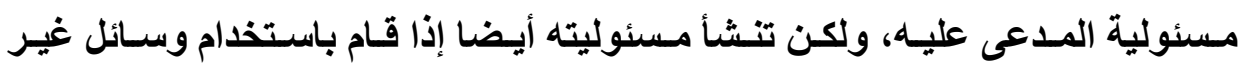

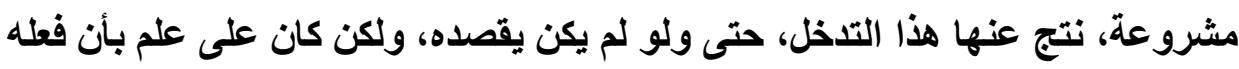

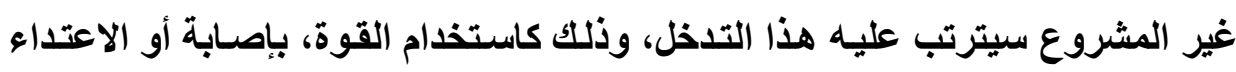

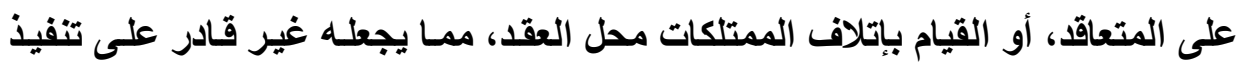

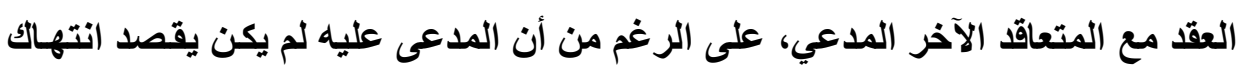

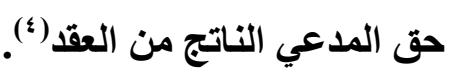

(1) Alex B. Long, previous reference, P. 4.

$$
\begin{aligned}
& \text { (r) مصطفى عبد الحميد عدوي، المرجع السابق، ص ^^؛ }
\end{aligned}
$$

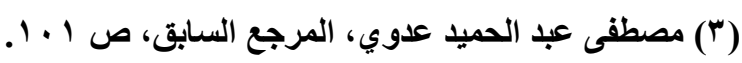

(4) Charles E. Carpenter, previous reference, P. 735. 
ففي قضية'(1) بين Sandlin v. Coyle، قام المدعى عليهم بتهيد مزارع

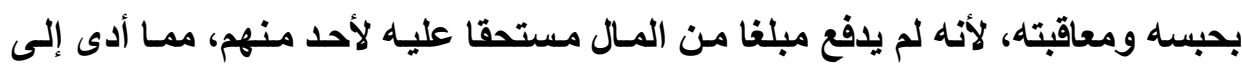

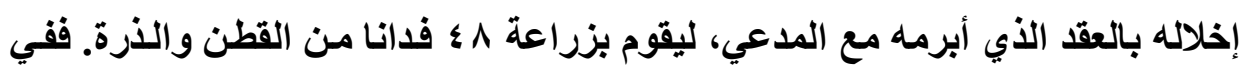

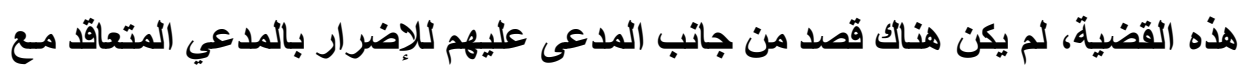

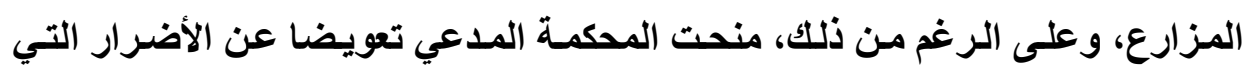
أصابته من جراء عدم تنفيذ العقد.

كذلك في حالة إضراب العمال، حيث يؤدي إلى عدم تنفيذ صـاحب العمل لعقود

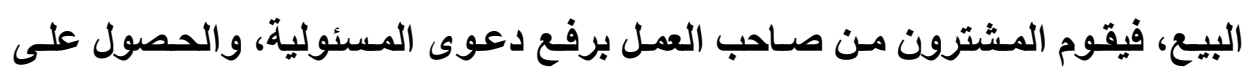

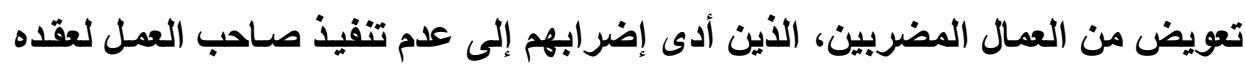

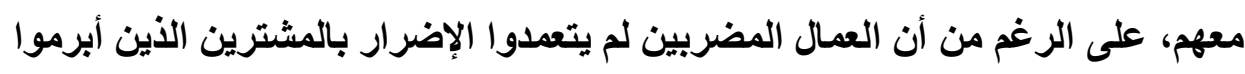

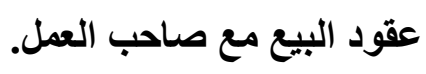

كما تنشأ مسئولية الثخص الذي تلدخل في العلاقة التعاقدية في الحالات التي

$$
\text { يستخدم فيها أسلوب الغش أو الاحتيال. }
$$

إذن لا تقتصر المسئولية على الحالات التي يتعمد فيها الثخص الثالث التدخل

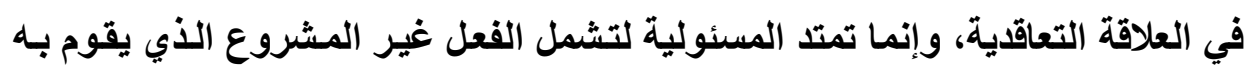

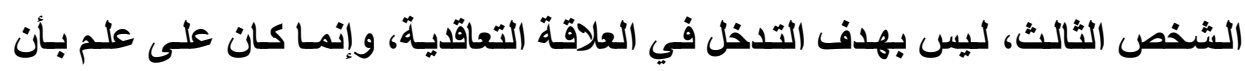

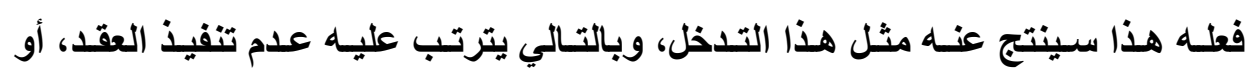

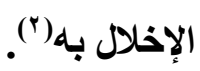

(1) Sandlin v. Coyle, 143 La. 121, 78 So. 261 (1918).

(2) Charles E. Carpenter, previous reference, P. 736, 737.

Vr. مجلة البحوث القانونيت والإقتصاديت 


\section{صور التدخل في العلاقات التعاقدية:}

قد يتمثل التدخل في العلاقات التعاقية في العديد من الصور، التي يمكن أن

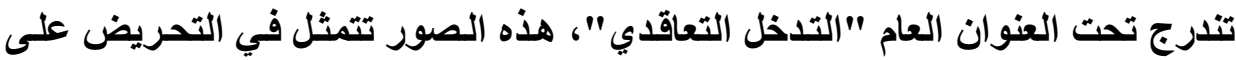
الإخلال بالعقد، والتدخل في تنفيذ العقد، والتدخل في المزايـا الاقتصادية المحتملـة،

$$
\text { وغيرها من الصور ('). }
$$

فيمكن للثخص المتلخل أن يدفع أو يحرض أحد أطراف العلاقة التعاقدية على

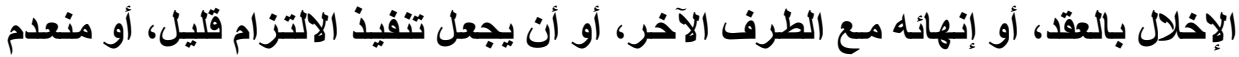

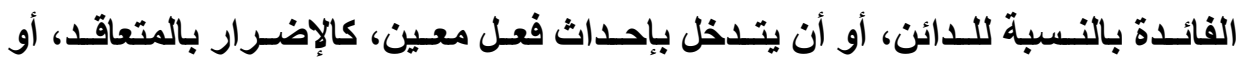
المتلكات محل التعاقد، على نحو يجعل تنفيذ الالتزام التعاقدي أكثر صعوبة، ألو أو إرهاقا

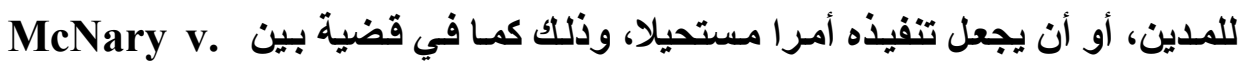
Chamberlain يلتزم المدعي بإصلاحه بموجب العقد، مما جعل تنفيذه لالتزامه أكثر تكلفة وإرهاقا. كما تطورت هذه النظرية تطورا فعالا في العديد من القضايا أو الحالات، عندما

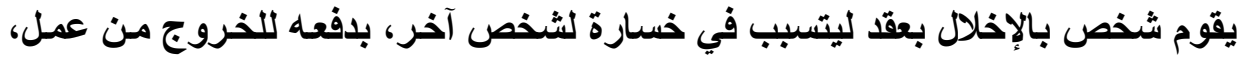
أو تجارة معينة، أو لجلب أو سحب المصلحة الاقتصادية من العقد له، بدلا من المداعي.

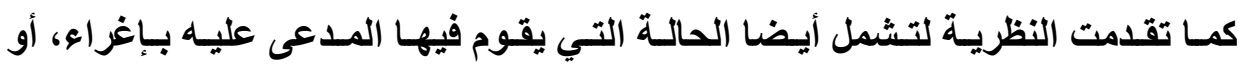
تحريض التجار، أو العملاء المتعاملين ميع المدعي، عن طريق استخام وسيائل غير الفير

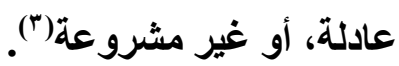

(1) John J. Fargo, Medical data privacy: Automated interference with contractual relations, Buffalo Law Review, Vol. 25, 1976, P. 506.

(2) McNary v. Chamberlain, 34 Conn. 384, 1867.

(3) Jerry C. Estes, previous reference, P. 349. 
وقد يقوم الشخص بالتـدل في العلاقة التعاقديـة بهـدف الإضـرار بالمـدعي،

بجعل العقد عديم الفائدة بالنسبة له، أو حتى دون وجود هذا القصد، ولكن مع علمه بأن الأن

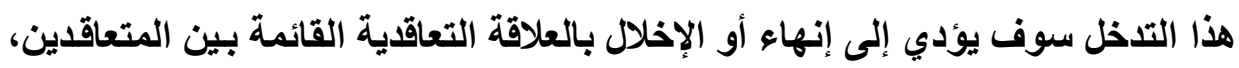

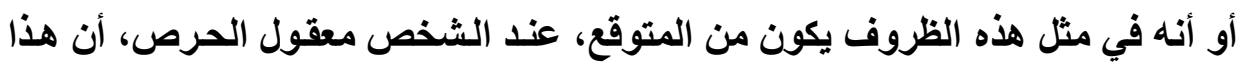

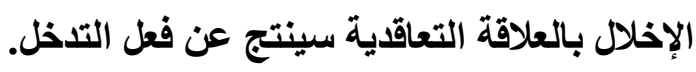

وهكذا يبدو أن صور التخخل في العلاقات التعاقدية أكبر نطاقا من مجرد الحث، أو التحريض على الإخلال بالعقد، حيث ينطوي الحث أو التحريض على الإخلال بالعقد على مجرد تعدد المتعاقد التحلل من التزامه التعاقدي (').

وبناء على ما تقدم، يمكنتا تقسيم أو تصنيف صور التدخل في العلاقات التعاقديـة على النحو الآتي:

\section{ا - التدخل بالتمريض على الإخلال بالهقد:}

تمثل صسورة التدخل بـالتحريض على الإخلال بالعقد أبسط صسورة من صور

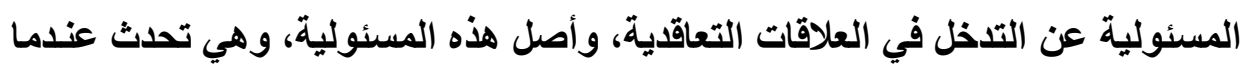

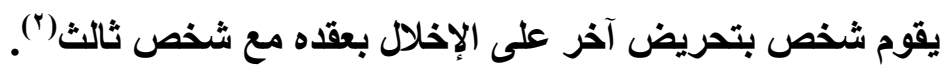
فتعد المسئولية عن التحريض بـالإخلال بعقد قـائم، صورة من التـخل غير

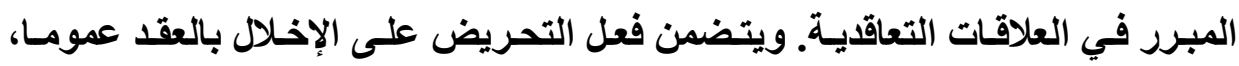

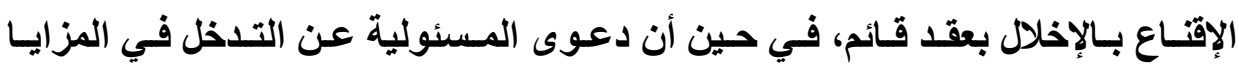

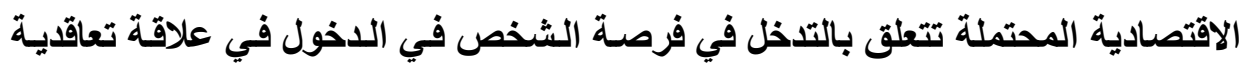

(1) Charles E. Carpenter, previous reference, P. 728.

(2) Jeanette Andersson, previous reference, P. 8.

(3) Jerry C. Estes, previous reference, P. 342. 
ولقد أصبح مبدأ راسـخا أنـه يمكن أن تنشأ المسئولية عن التحريض على

الإخلال بالعقد، أيا كان نوع العقد، أي سواء كان محله تقديم خدمات شخصية، أو توريد

$$
\text { مواد، أو أي نوع آخر من العقود (') }
$$

ويطلق البعض على هذه الـصورة مـن صـور التـدخل في العلاقـة التعاقديـة

مصطلح "التحريض المدني"، وهو يتطلب توافر بعض العناصر لإثبات وجوده، وهي هوهي

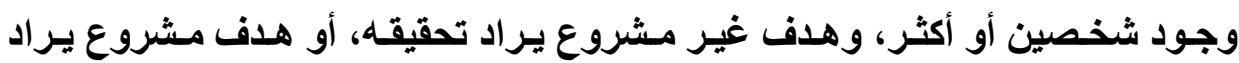

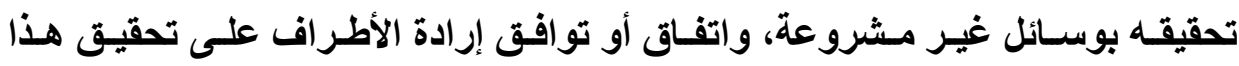

الهذف، وتصرف غير مشروع، ووقوع أضرار تبعا لذلك(").

وتجدر ملاحظة أنه قد تتقرر أيضا المسئولية التقصيرية للمتعاقد الذي أخل

بالعقد، بسبب قيامة بالتآمر والتواطؤ مع الطرف الثالث على القيام بهذا الإخلال(").

ويثور التساؤل: هل مجرد تـدخل الشخص فـي علاقـة تعاقديـة، عن طريـق

تحريض المتعاقد بالإخلال بالعقد، وعدم تنفيذه، دون أن يستخدم هذا الشخص وسـائل

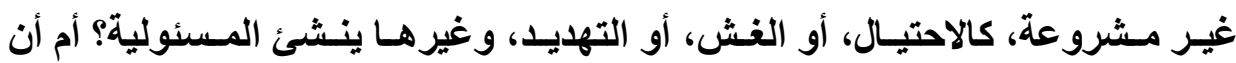
المسئولية تقتصر على تلك الحالات التي يستخدم فيها الشخص هذه الوسائل؟

إن من المعترف به، في الولايات المتحدة الأمريكية، وإنجلترا، أن تحريض أحد

المتعاقدين على الإخلال بالعقد، عن طريق استخدام القوة، أو التهديد باستخدامها(؛)، أو

استخدام وسائل الاحتيال، والغش ينشئ المسئولية" (')

(1) Charles E. Carpenter, previous reference, P. 729.

(2) Brand Lawless Cooper, previous reference, P. 306.

(3) Clark A. Remington, previous reference, P. 652.

(4) Dunshee v. Standard Oil Co., 152 Iowa 618, 126 N. W. 342, 132 N. W. 371 (1911). Chambers v. Probst, 145 Ky. 381, 140 S. W. 572 (1911). 
بيــ أنـه، في معظم الولايـات القضائية الأمريكيـة، قد تنشأ المسئولية عن التحريض على الإخلال بالعقد على الرغم من عدم استخدام وسائل التهديد، أو استعمال

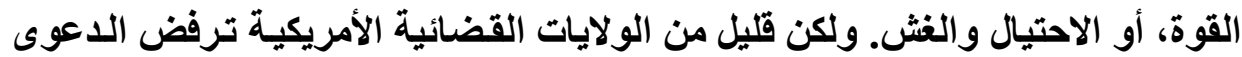
إذا لـم يـتم اسـتعمال وسـيلة مـن هـذه الوسـائل، عند تحريض المتعاقـ على الإخـلال

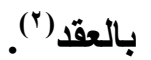

وعلى ذلك قد يتضمن التحريض على الإخلال بالعقد استخدام المدعى عليه. لوسـائل غير مشروعة، كالتهديد، ولكن أيضا يمكن أن يتم في صسورة حوار هـادئ وسلمي) (ب)

فمن المسلم بـه أن المدعى عليه، الذي يتعمد الإضرار بالمـدعي، عن طريق تحريضه، أو إقناعه للمتعاقد بأن يخل أو يتحلل من علاقته التعاقدية مع المدعي، لاسيما

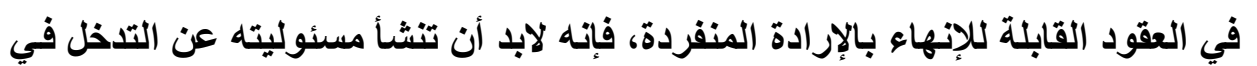
العلاقة التعاقدية، ويجب عليه تعويض الضرر الواقع على المدعي نتيجة لذلك(؛). وتطبيقا لذلك، فالمحكمة العليـا في الولايـات المتحدة الأمريكية(ْ)، والمحسكم الفيدرالية(')، وكذلك المحاكم في معظم الولايات()، قد أقرت واعترفت بـالحق في رفع

(1) Koch v. Burgess, 167 Iowa 727, 149 N. W. 858 (1914). Fed. Sugar Ref. Co. v. S. Sugar Equalization Board, 268 Fed. 575 (S. D. N. Y. 1920).

(2) Charles E. Carpenter, previous reference, P. 730.

(3) Jeanette Andersson, previous reference, P. 8.

(4) Charles E. Carpenter, previous reference, P. 743.

(5) Hitchman Coal and Coke Co. v. Mitchell, 245 U. S. 229 (1917). The United States Supreme Court explicitly pointed out that: "The right of action for persuading an employee to leave his employer is universally recognized". Charles E. Carpenter, previous reference, P. 744. 
دعوى المسئولية على المـدعى عليه الذي يقنع، أو يحرض العامل على الإخلال، أو التظلي عن العقد بينه وبين صاحب العمل. وبالتالي فقد اعترفت هذه المحاكم بمسئولية المـدعى عليـه إذا اسـتخدم مجرد التحريض فتط، أو الحث على الإخـلال بالعقد، دون اشتر اط أن يستخدم وسائل غير مشروعة.

ومن ثم فتصرف المدعى عليه غير المشروع، الذي يهدف إلى التأثير على المتعاقد، سواء بصورة مباشرة، أو غير مباشرة، من خلال عدة طرق، كالتحريض، والإقتـاع، والتهديـد، ليتصرف على نحو يسبب أضـرارا اقتصادية للمـدعي، ينشئ

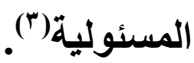

وجدير بالـذكر أن إعـلان شـخص عـن صـفقة تجاريـة جذابـة للجمهور، مـع

الثعور بأن ذلك قد يدفع شخصا مـا للإخلال بعقده مـع الغير، ليدخل في هذه الصفقة

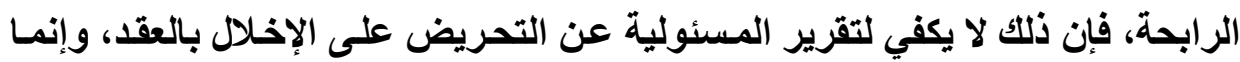
يجب إثبات أن المدعى عليهه قد قام فعلا بتحريض شـص مـا على الإخلال بعقده مـع

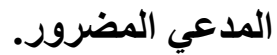

وتجدر ملاحظة أن هناك فرقا واضحا بين التحريض على الإخلال بالعقد، وبين

النصيحة بالإخلال بالعقد، حيث يتضمن التحريض على الإخلال بالعقد على خلق المدعى التح

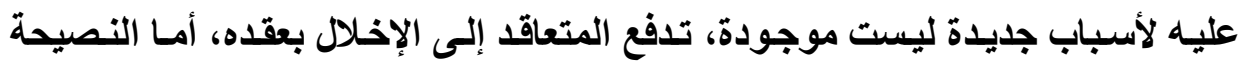

(1) Triangle Film Corp. V. Arteraft Pictures Corp., 250 Fed. 981 (C. C. A. 2d, 1918).

(2) United States Fidelity and Guaranty Co. v. Millonas, 206 Ala. 147, 89 So. 732 (1921); Moore Drop Forging Co. v. McCarthy, 243 Mass. 554, 137 N. E. 919 (1923).

(3) Jeanette Andersson, previous reference, P. 7. 
فتتضمن قيام الثخص بتنبيه المتعاقد لأسباب موجودة بالفعل، تدفعه إلى نصيحته بأنه من الأفضل أن يتحلل من هذا العقد (').

\section{r- التدخل في تنفيذ العقد باستخدام وسائل غير هشروعة:}

تتمثل الصورة الثانية من صور المسئولية التقصيرية عن التدخل في العلاقات التعاقدية في الفرض الذي يقوم فيه المدعى عليهه بتعجيز المتعاقد، رغمـا عن إرادته، هونه عن تتفيذ عقده مع المدعي، أي جعله غير قادر على تنفيذ التزامه، على الرغم من أنسه

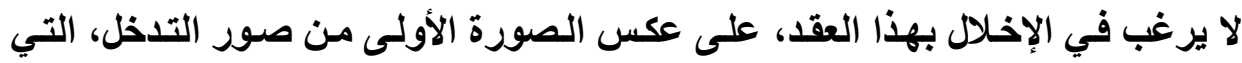
تقوم على تحريض المتعاقد على الإخلال بالعقد، فيقوم بالإخلال به بإرادته. ومما لاشك فيه أنه، في هذه الصورة من صور التدخل في العلاقات التعاقدية،

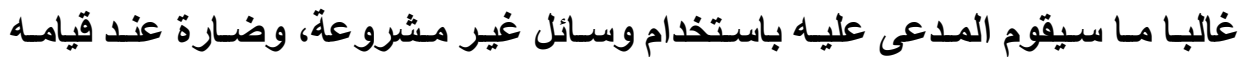

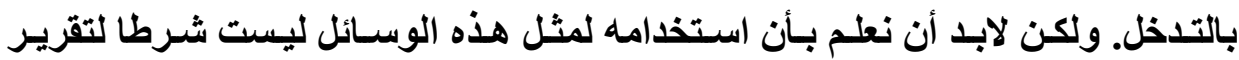

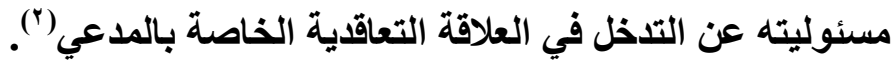
وتظبيقا لما تقدم، قد تنشأ المسئولية عن التدخل في العلاقات التعاقدية على الرغم من عدم التحريض على الإخلال بالعقد القائم ببين المتعاقدين، وذلك كإصسابة، أو

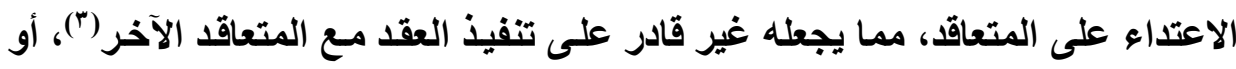

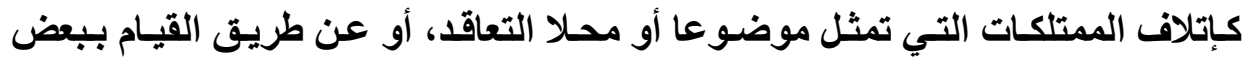
الأفعال الأخرى التي تجعل تنفيذ الالتزام مرهقا، أو مستحيلا على المتعاقد، أو أن تجعل

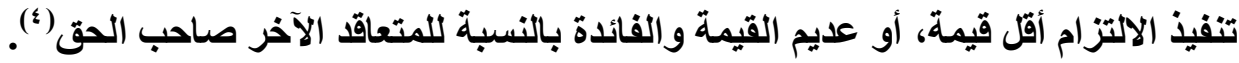

(1) Jeanette Andersson, previous reference, P. 8.

(2) Jeanette Andersson, previous reference, P. 9.

(3) Bradford v. Webster, (1920) 2 K. B. 135.

(4) McNary v. Chamberlain, 34 Conn. 384 (1867); Glanzer v. Shepard, 233 N. Y. 236, 135 N. E. 275, 276 (1922). 
و وعلى ذلك تتعدد الوسائل الضارة، أو غير المشروعة التي يمكن للمدعى عليه

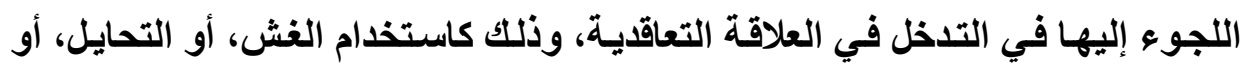

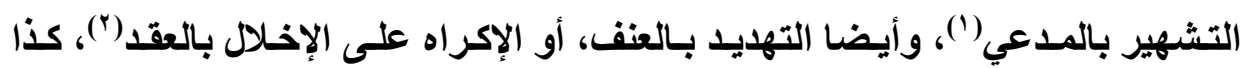

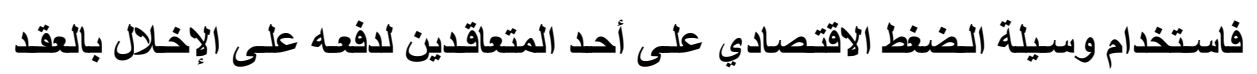
ينشئ المسئولية) (").

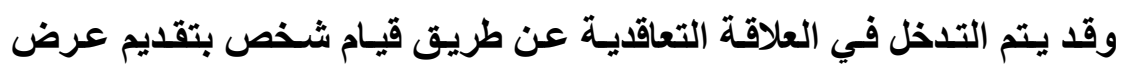

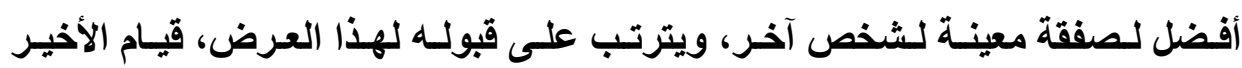

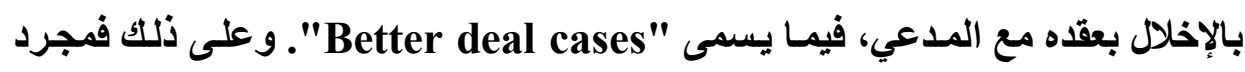

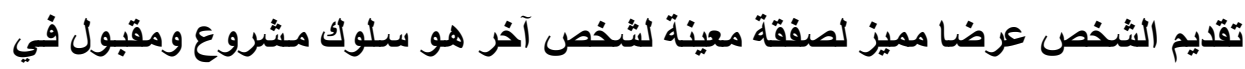

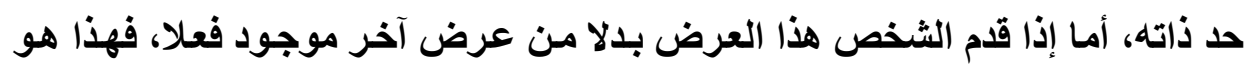

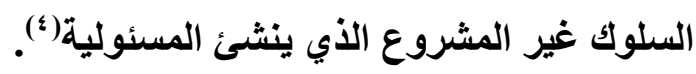

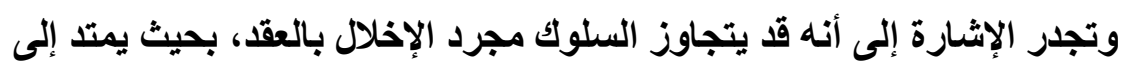

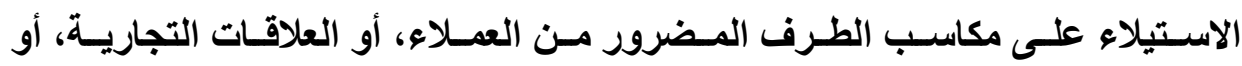

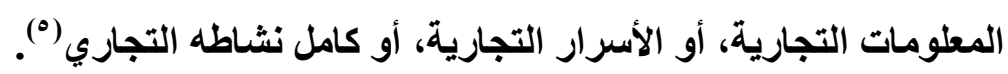

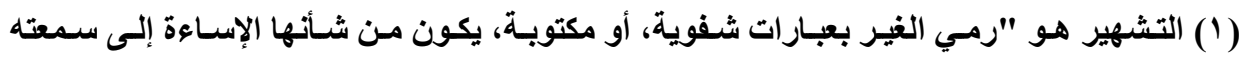

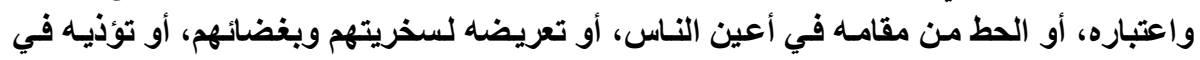

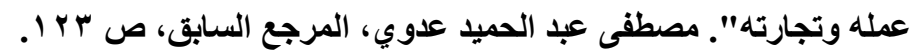

(2) Jerry C. Estes, previous reference, P. 348.

(3) Charles E. Carpenter, previous reference, P. 744.

(4) Clark A. Remington, previous reference, P. 654.

(5) Jerry C. Estes, previous reference, P. 350. 
ويلاحظ أنه، في بعض الولايـات القضائية(')، لا تتقرر المسئولية عن التدخل

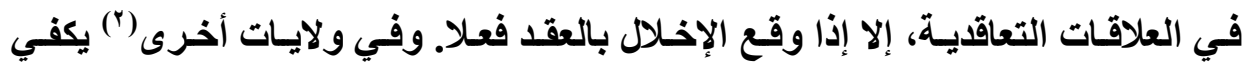

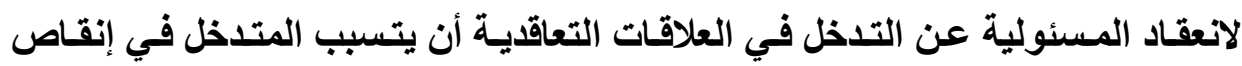
الحقوق التعاقدية للمدعي.

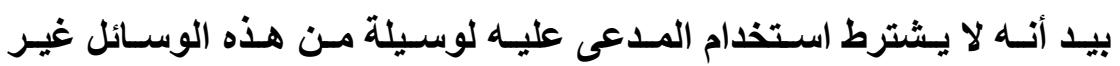

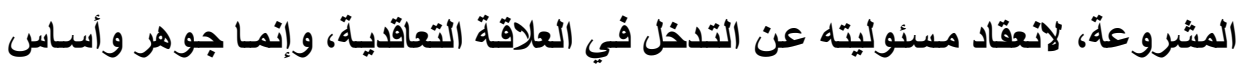

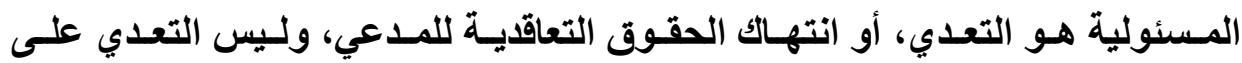

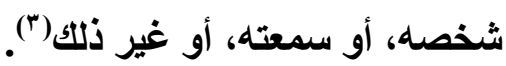

فقي معظم الولايـات القضائية، يمكن أن تنعقد مسئولية المدعى عليه عن

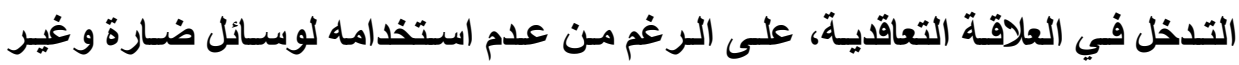
مشروعة. فمجرد إقناع الثخص بالإخلال بالعقد يكفي لانعقاد المسئولية. فعلى الرغم من عدم استخدام المدعى عليه لوسـائل غير مشروعة أو ضسارة

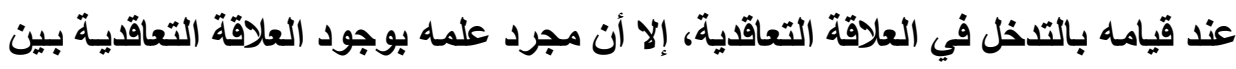

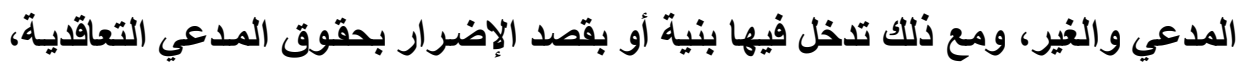

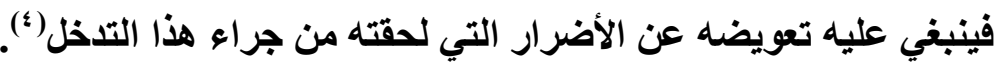

(1) NBT Bancorp Inc. v. Fleet/Norstar Financial Group, Inc., 664 N.E.2d 492, 496 (N.Y. 1996). Clark A. Remington, previous reference, P. 651.

(2) Pacific Gas \& Elec., 791 P.2d at 592; Lewis v. Oregon Beauty Supply Co., 733 P.2d 430, 434 (Or. 1987). Clark A. Remington, previous reference, P. 651.

(3) Jerry C. Estes, previous reference, P. 348.

(4) Jerry C. Estes, previous reference, P. 349. 
وبناء على ما تقدم، قد يرى البعض أن الوسائل التي يستخدمها المدعى عليه

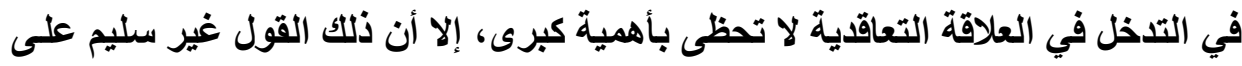

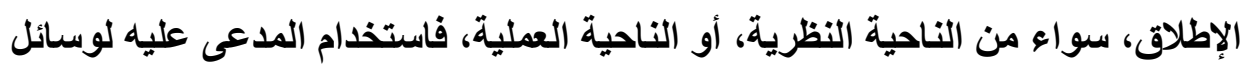

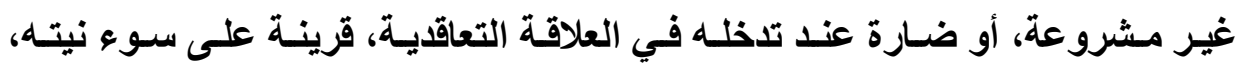
وتعدده إلحاق الضرر بالمدعي، كذلك فإن المدعى عليه إذا دفع مسئوليته بأن تدخله في العلاقة التعاقديـة كـان مبررا، فإن الوسـائل التي استخدمها في التدخل هي العامل، أو

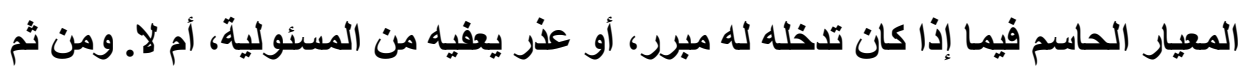

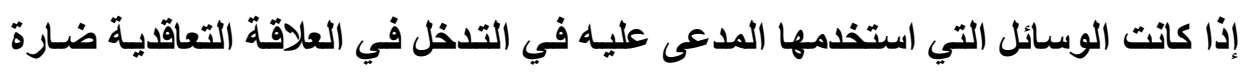
وغير مشروعة، فإن المبرر أو العذر الذي يدفع به مسئوليته لن يقبل (').

\section{r- التدخل غيز المباشر في العلاقات التعاقدية:}

تتمثل صورة التدخل غير المباشر في العلاقة التعاقديـة في الفرض الذي يقوم

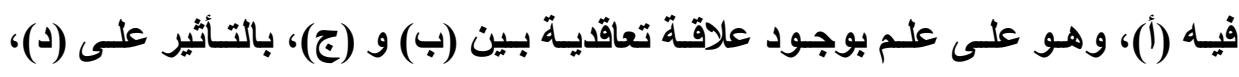

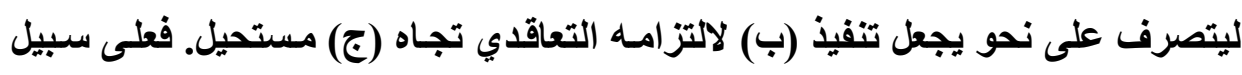

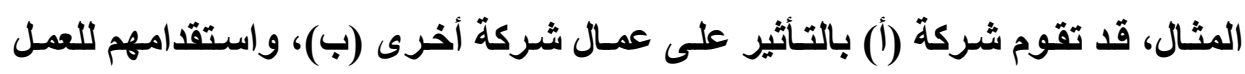

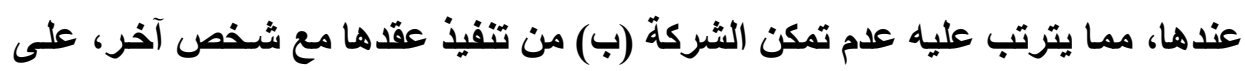

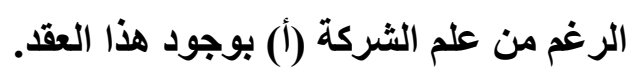

ولا تتقرر مسئولية المدعى عليه عن التذخل غير المباشر في العلاقة التعاقدية إلا إذا قام باستخدام وسائل غير مشروعة عند قيامه بهذا التدخل، وذلك على العكس في

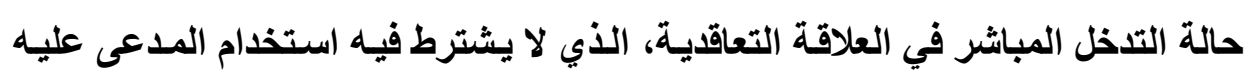
لوسائل غير مشروعة"(†)

(1) Jerry C. Estes, previous reference, P. 347.

(2) Jeanette Andersson, previous reference, P. 9. 


\section{حكم التدخل في العلاقة التعاقدية الناتج عن الإههال:}

الخطأ غير العمدي "يكون عندما يقع الإخلال بواجب قانوني، بغير أن يتجـه

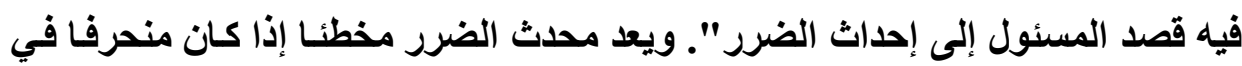

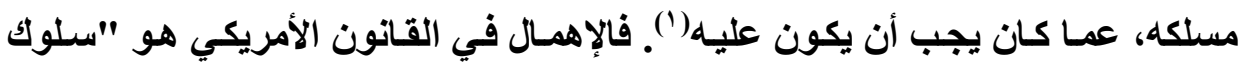

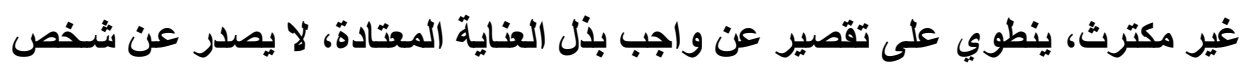

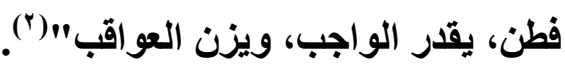

وقد يقوم شخص بفعل معين ينطوي على إهمال، يؤدي إلى إخلال أو عدم تنفيذ

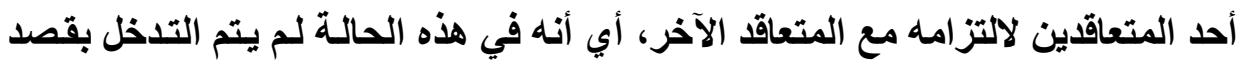
الإضرار بالمدعي المتعاقد.

وينـاء على ذلــك يثور التساؤل: هـل تمتـــ المسئولية لتشمل الفعـل الــي

ينطوي على إهمال، والذي يـؤدي إلى التدخل في العلاقة التعاقديـة، وبالتـالي الإخلال بالعقد؟

لم تتوحد أحكام القضاء الإنجليزي والأمريكي في اعتبار التدخل، الذي يتم بإهمال، دون تعدد الإضرار بالمتعاقد، كسبب لنشوء المسئولية.

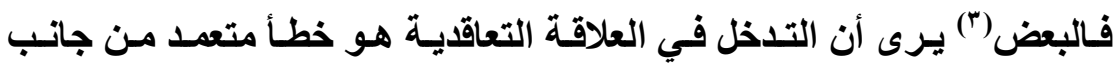

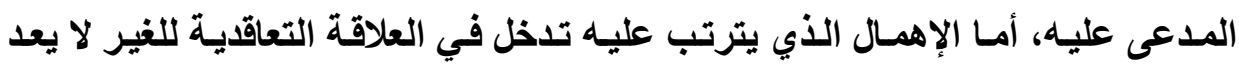

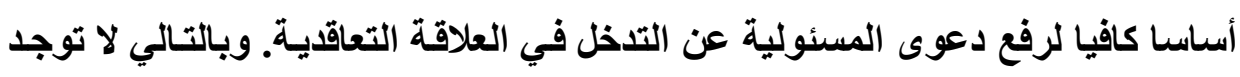
مسئولية إذا تم التـخل في العلاقة التعاقديـة دون تعمد الإضرار بالمتعاقد، و إنمـانتج

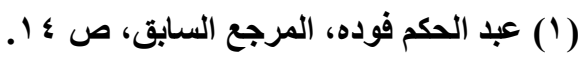

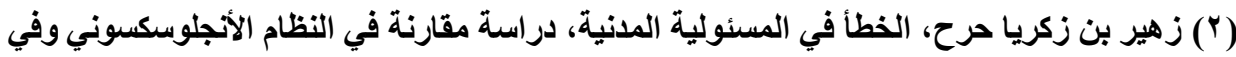

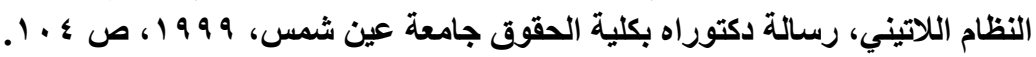

(3) Peter Edmundson, previous reference, P. 6. 
الإخلال بالعقد عن إهمال شخص ثالث، فلا يكون هذا الأخير مسئولا عن عدم تتفيذ

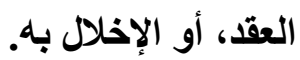

وتطبيقا لذلك في قضية(') بين Cattle v. Stockton، كان المدعى عليه

شركة مياه للصرف الصحي، تسببت بإهمالها في وجود تسريب بالمياه في أنبوب المياه

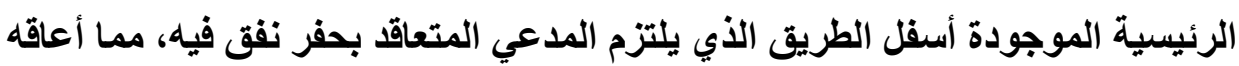

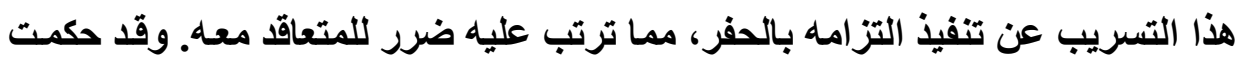

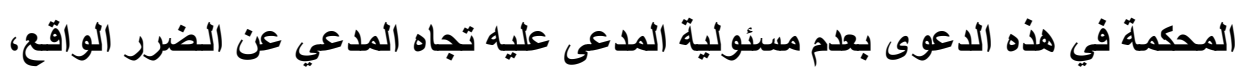

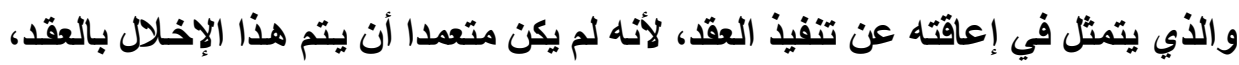

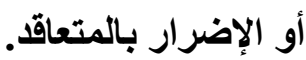

وأيضا في قضية(') بين Connecticut Mutual life insurance company v. New York and New Haven R. R. القضية في أن المدعى عليه كان شركة السكك الحديدية، تسبيت بإهمالها في وفاة

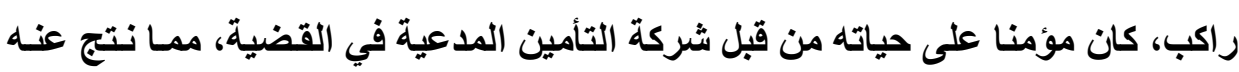

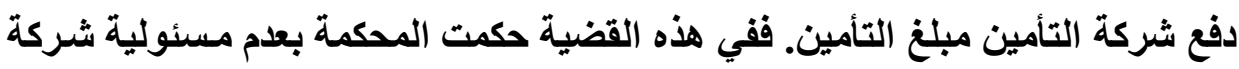

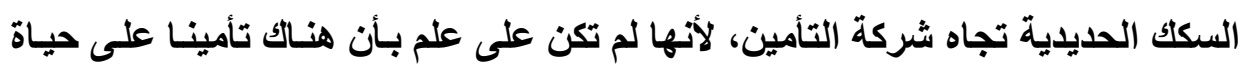

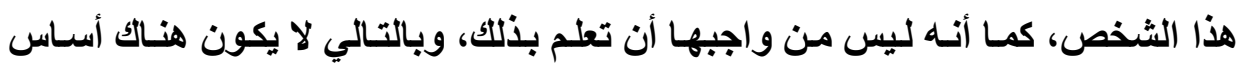

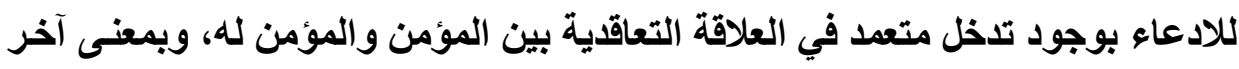

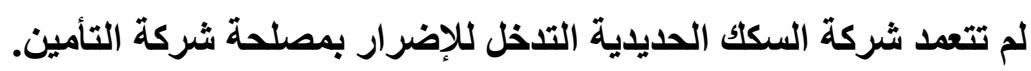

(1) Cattle v. Stockton L. R. 10 Q. B. 453 (1875).

(2) Connecticut Mutual life insurance company v. New York and New Haven R. R. 25 Conn. 265 (1856). 
وفي قضية أخرى (') بين Byrd v. English، تتلخص وقائعها في أن المدعي كان متعاقدا على أن يورد طاقة كهربائية، وقد أصبح تنفيذ هذا العقد مستحيلا

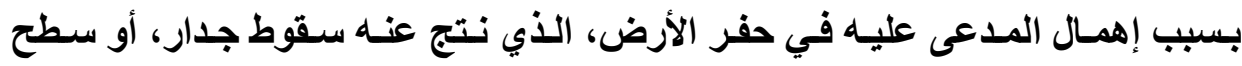
الأرض، على الأنابيب التي تحتوي على التيبار الكهربائي الخـاص بالمدعي، ممـا جعل التل

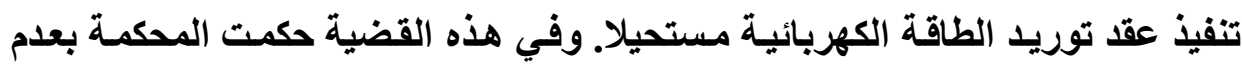

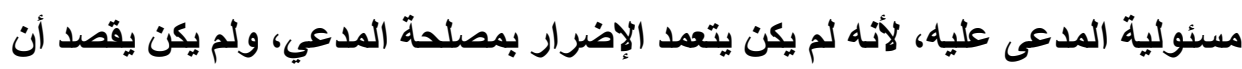
يجعل تنفيذ العقد مستحيلا.

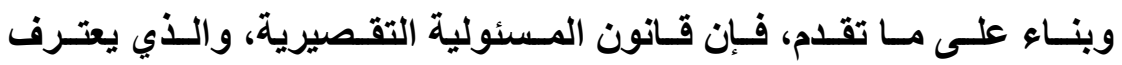

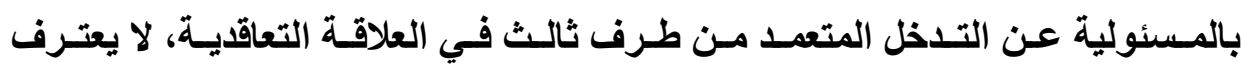

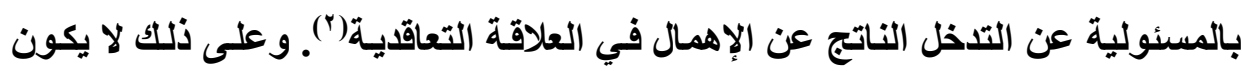
الثخص مسئولا تجاه المتعاقد المضرور عن الإهمال الذي يترتب عليه إصـابة المتعاقد الإهد

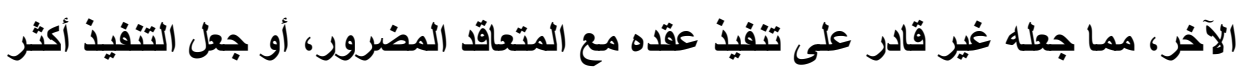

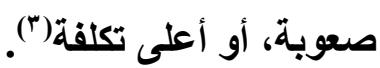

وعلى العكس من ذلك، فالبعض من المحاكم(") يرى أن إهمال الشخص، الذي

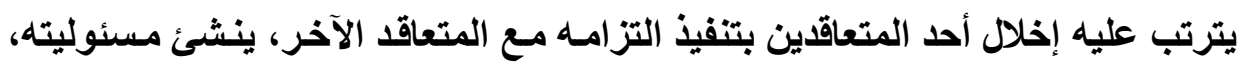

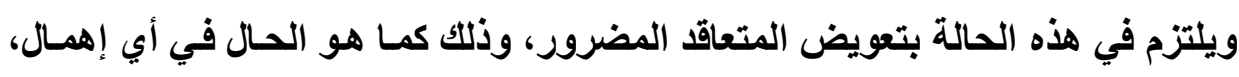

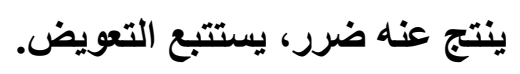

(1) Byrd v. English 117 Ga. 191, 43 S. E. 419 (1903).

(2) Peter Edmundson, previous reference, P. 6.

(3) Leonard J. Long, An Uneasy Case for a Tort of Negligent interference with Credit Contract, Law Review Association of the Quinnipiac University School of Law, 2003, P. 1, 2.

(4) Jones v. Brown, 1 Esp. 217 (1794); Martinez v. Gerber, 3 Man. And G. 88 (1841). 
وتطبيقا لألك، ففي بعض القضايا الأمريكية، يسمح بمنح تعويض للمدعي إذا تم

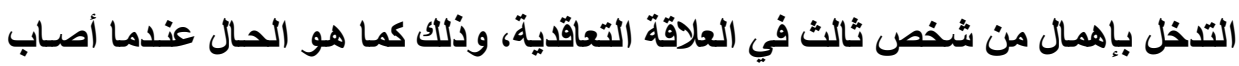

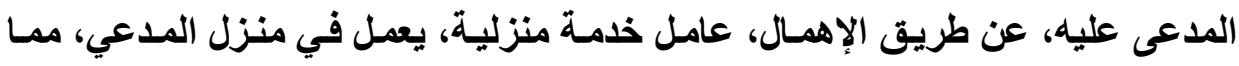

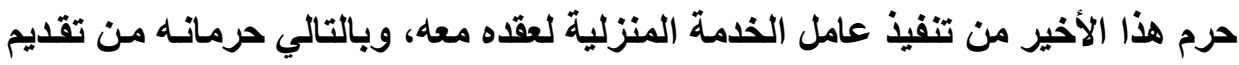
(الخدمة (1) (1)

كذلك في قضية(广) بين Cue v. Breeland، قضت المحكمة بمسئولية

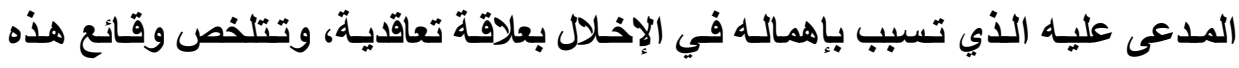
القضية في أن المدعى عليه تسبب بإهماله في تدمير الكوبري الذي تعاقد المدعي مـع الغير على القيام بإصلاحه.

وباستقراء ما سبق، نجد أنتا نؤيد ما تذهب إليه المحاكم التي ترى عدم مسئولية

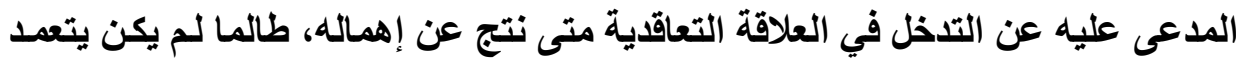

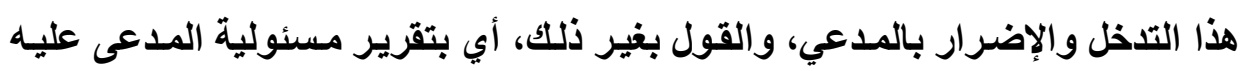

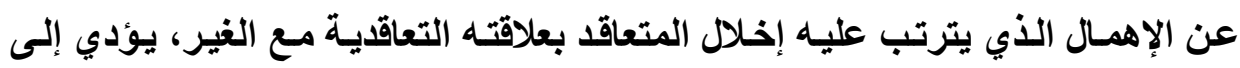

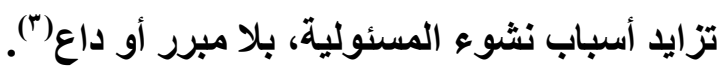
هدى اشتزاط سوs النية لتقريز المسئولية: قـ يتعمد الشخص التـخل في العلاقـة التعاقديـة لتحقيق مصلحة معينـة لـه،

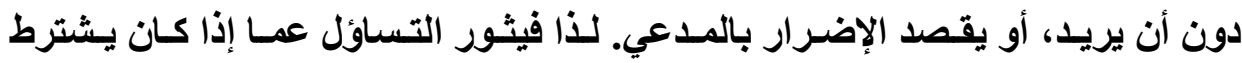

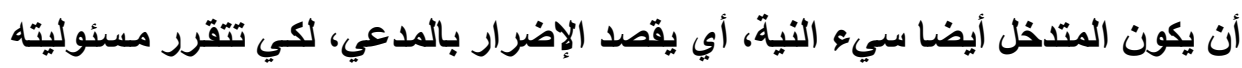

(1) Ames v. Union Ry., 117 Mass. 541 (1875).

(2) Cue v. Breeland, 78 Miss. 864, 29 So. 850 (1901).

(3) Charles E. Carpenter, previous reference, P. 742. 
في الواقع إن المحاكم التي تقرر المسئولية عن التدخل في العلاقات التعاقدية، لا

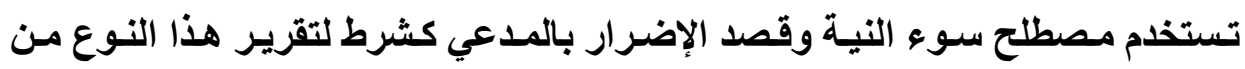
المسئولية، وإنما تستخدمه لتعني أو تقصد أن التحريض على الإخلال بالعقد كسان غير

إذن فسوء نية المدعى عليه ليست عنصرا من عناصر المسئولية عن التدخل

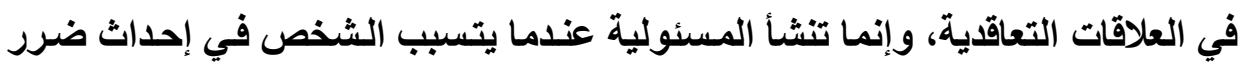
بالمدعي، نتيجة لتحريضه المتعاقد الأخر على الإخلال بالعقد (')

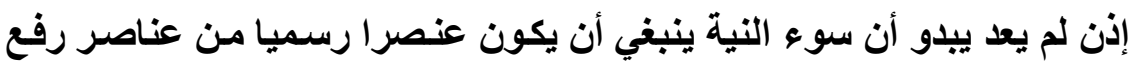

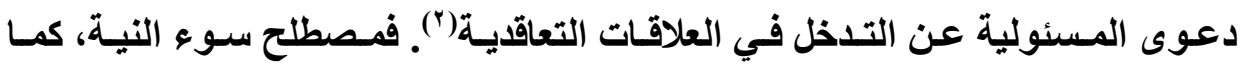

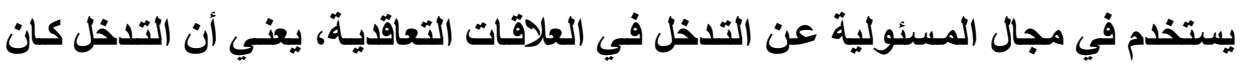

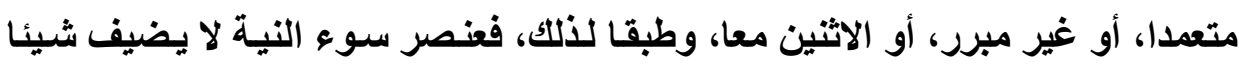
جديدا في تحديد مدى مشروعية التدخل في العلاقة التعاقدية(").

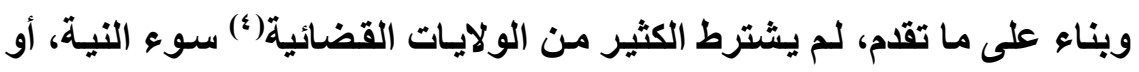

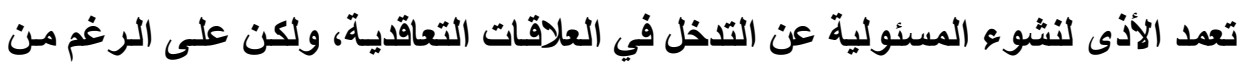

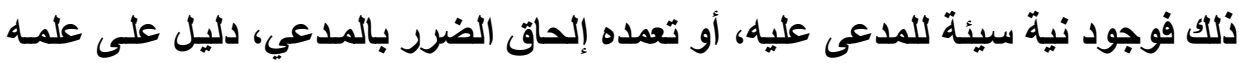

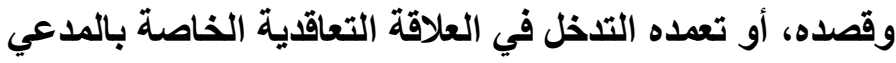

(1) Charles E. Carpenter, previous reference, P. 734, 735.

(2) Odette Woods, previous reference, P. 5. Fred S. McChesney, previous reference, $P .16$.

(3) Gary Myers, previous reference, $P .1113$.

(4) E.g., A.S. Rampell, Inc. V. Hyster Co., 3 N.Y.2d 369, 144 N.E.2d 371 (N.Y. App. 1957). 


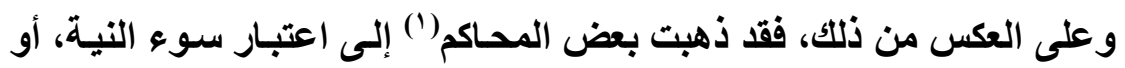

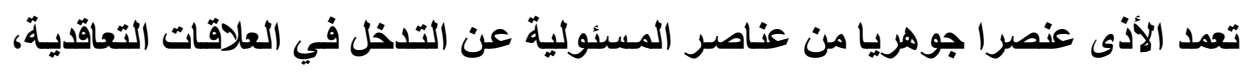

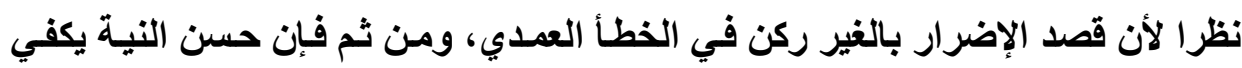
لنفي خطأ العمد (؟). وتجدر الإشارة إلى أن بعض الو لايات القضائية(") تعرف سوء النية بأنه عدم

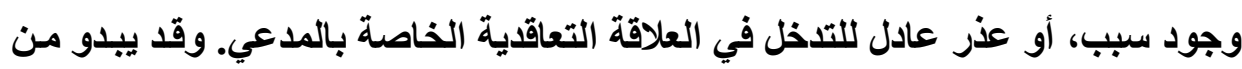

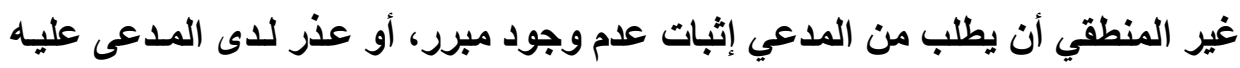

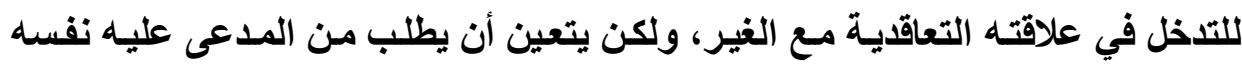

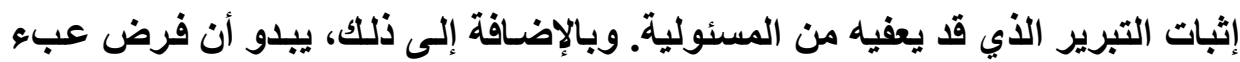

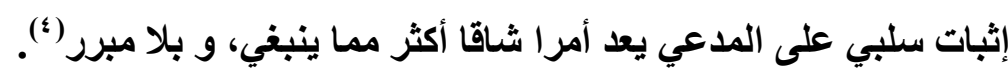

\section{المطب الثالث}

\section{الضـرر}

إذا قام شخص متعمدا بالتبخل في العلاقة التعاقدية بين شخصين، كان مسئولا عن

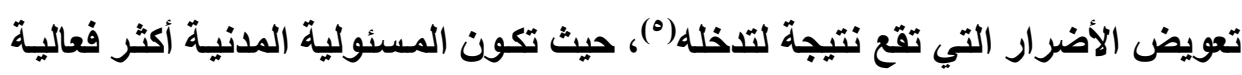

(1) Elliot v. Elliot, 482 S.W.2d 123 (Ark. 1972); Steffan v. Zernes, 124 So. 2d 495 (Fla. App. 1960); O'Connor V. Harmes, 111 N.J. Super. 22, 266 A.2d 605 (N.J. App. 1970).

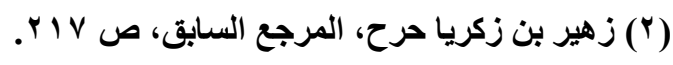

(3) Louis Schlesinger Co. V. Rice, 4 N.J. 169, 72 A.2d 197 (1950).

(4) Jerry C. Estes, previous reference, P. 343.

(5) Clark A. Remington, previous reference, P. 650. 
في حالة الأضرار المنصبة على الأعمال التجارية، مثل تلك التي تتثأ عن المنافسة غير

ولا شك في أن المسئولية عن التحريض على الإخلال بالعقد تتدرج ضمن

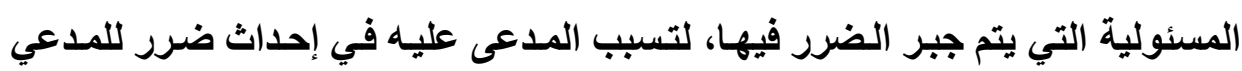
يتعلق بعلاقاته التجارية.

فقد تتضرر المصالح، أو الحقوق التعاقدية للمدعي، نتيجة لقيام المدعى عليه

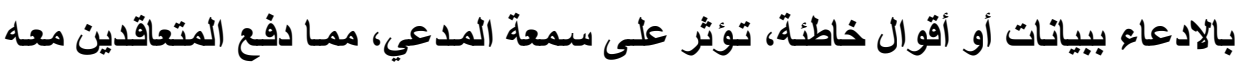

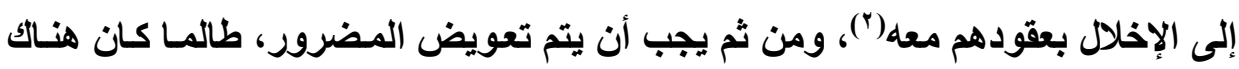
إخلال بحقى، أو مصلحة مالية له (") الأن

إذن فالثخص الذي تتقرر مسئوليته عن التنخل في العلاقات التعاقدية، يكون

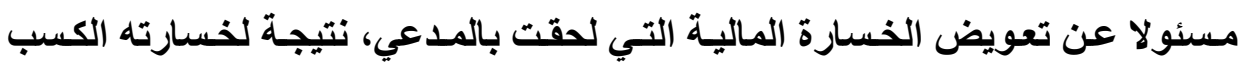

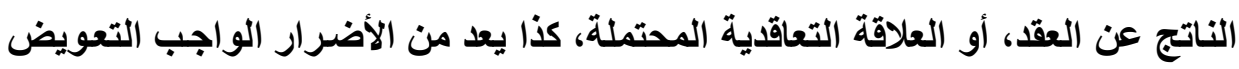

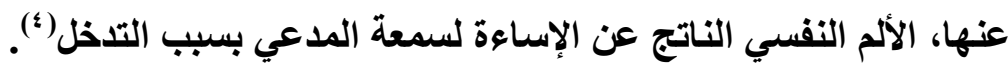

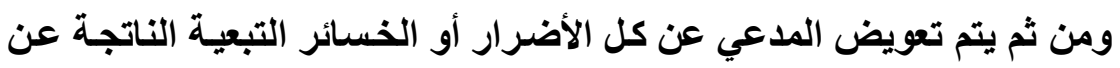

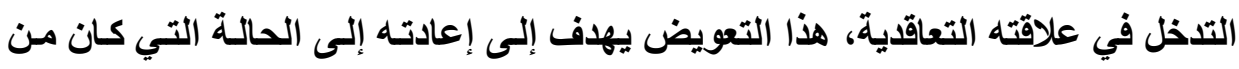

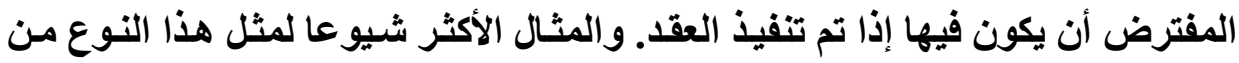

(1) محسن عبد الحميد البيه، حقيقة أزمة المسئولية المدنية ودور تأمين المسئولية، المرجع السابق، . ص v

(2) Fowler V. Harper, Interference with contractual relations, Inducing breach of contract, Northwestern University Law Review, Vol. 47, 1953, P. 873.

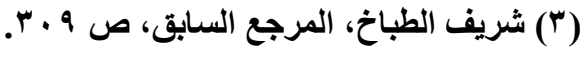

(4) Sandra S. Baron, Hilary Lane, and David A. Schulz, previous reference, P. 1057, 1058. 
الأضرار يتمثل في الكسب الفائت، حيث يجوز تعويض المدعي عن الكسب الذي فاته، متى قام باثبات أن هذا الكسب الفائت كان نتيجة طبيعية ومحتملة للفعل المرتكب، وأن

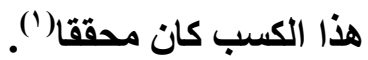

ولا شك في أنه ينبغي التفرقة بين الضرر المحتمل، والذي لا يسأل المدين عن

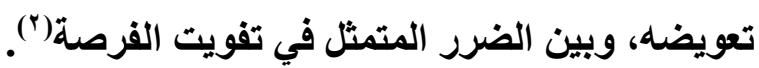

فتفويت الفرصة أمر محقق، رغم أن الفرصة في حد ذاتها هي أمر احتمـالي،

وبالتالي يجب التعويض عن تفويت الفرصة، حيث ياخل في عناصر التعويض مـاكـان

يأمل المضرور الحصول عليه من كسب من وراء تحقق الفرصة، بشرط أن يكون هذا تهوبات قائما على أسباب معقولة ومقبولة، ترجح كسبا فوته عليه العمل غير المشروع. وقد مند

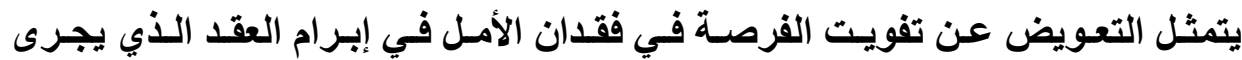

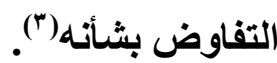

(1) A plaintiff also may seek "consequential losses for which the interference is a legal cause". The gauge of such damages is "the amount necessary to put the plaintiff in as good a position as it would have had if its agreement had been performed". A common type of consequential damages at issue in the tortious interference context is lost profits. Generally, "an injured party may recover damages for lost profits by showing that the loss is a natural and probable result of the act or omission complained of and that the amount of profits that the party would have earned is reasonably certain". Sandra S. Baron, Hilary Lane, and David A. Schulz, previous reference, P. 1060.

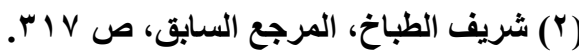

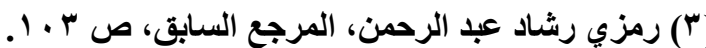




\section{الإطلب الرابع \\ علاتة السببية بين التدخل في العلاقة التعاقدية والضرر}

إن علاقة السببية ركن أساسي من أركان المسئولية، وشرط لازم لقيامهاب(')

فالشخص يجب أن يسأل عن نتائج أخطائه، وبالمقابل لا يكون مسئولا إذا إذا لم يتسبب في

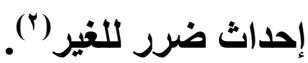

ومسن ثم يشترط، حتى تنشأ مسئولية المـدعى عليهه عن التـخل في العلاقة

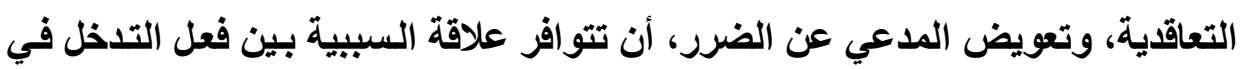

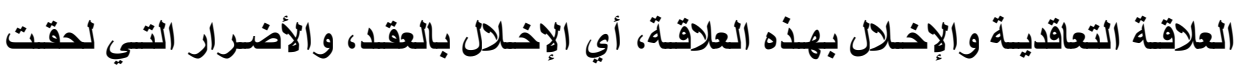

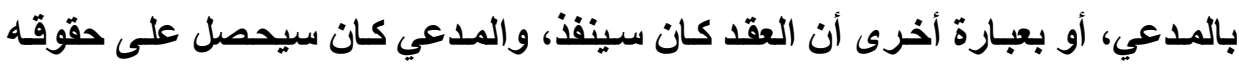

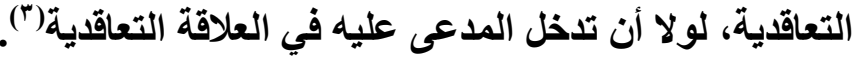

وتطبيقا لما تقدم، إذا أثبت المدعى عليه أن الضرر لـ يكن راجعا إلى خطئه،

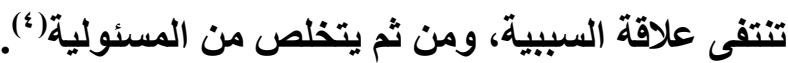

كما يمكن للمدعى عليه أن يتهرب من المسئولية عن طريق إثباته أن تدخله في

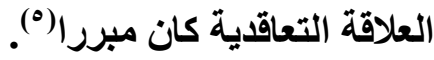

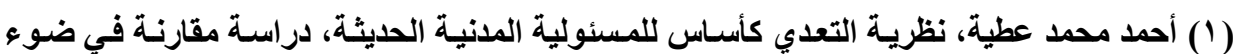

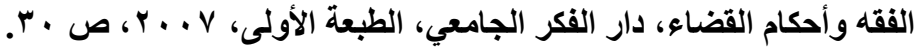

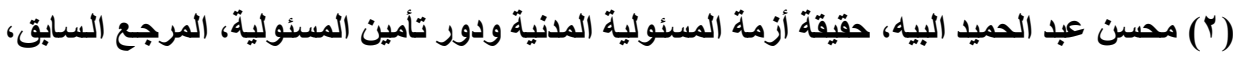

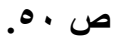

(3) Jeanette Andersson, previous reference, P. 10.

$$
\text { (؛) زهير بن زكريا حرح، المرجع السابق، ص } 9 \text { ؟ 1. }
$$

(5) If the interference is prima facie tortious, then to escape liability the defendant must convince us with something like the following: "My violation of an existing contract right was justified because I sought to further my own economic interest". Clark A. Remington, previous reference, P. 667. 


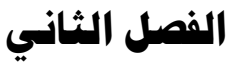 \\ جزاء المسئولية التقصيرية عن التدخل في العلاقات التعاقدية \\ وحالات الإعفاء هنها}

\section{تمهيد وتقسيم:}

متى توافرت أركان المسئولية التقصيرية عن التذخل في العلاقة التعاقدية، ينشأ

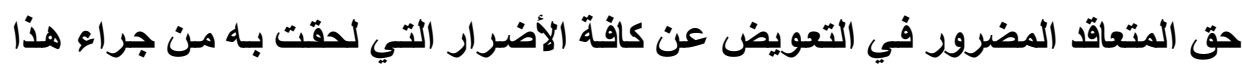

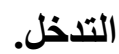

ويلاحظ أن هناك حالات، متى توافرت، فإنها تجيز إعفاء المتلخل من المسئولية

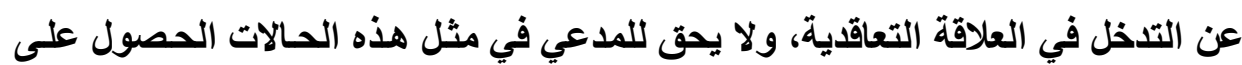

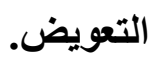
وبناءً على ما تقلد، نرى تقسيم هذا الفصل إلى مبحثين، وذلك على النحو الآتي: المبــث الأول: جزاء المسئولية التقصيرية عن التدخل في العلاقات التعاقية

$$
\text { (التعويض). }
$$

المبــث الثـاني: حـالات الإعفـاء مـن المسئولية التقصيرية عن التـذل في

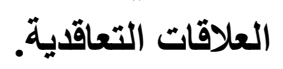




\section{المبحث الأول \\ جزاء المسئولية التقصيرية عن التدخل في

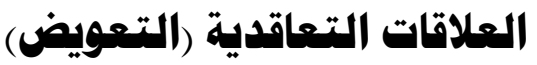

تمهيد وتقنسيم:

متى تقررت المسئولية التقصيرية للمتدخل في العلاقة التعاقديـة، تقوم معظم

المحاكم بمنح المدعي المضرور تعويضات تغطي كل أنواع الأضرار التي وقعت عليه،

بسبب تدخل المدعى عليه في العلاقة التعاقدية، فهي تعوضه عن الأضرار الفعلية التي

أصابته، بالإضافة إلى منحه تعويضات عقابية، تفوق أو تزيد عن الضرر الفعلي، وإنمـا

يدفعها المدعى عليه عقابا له على فعله غير المشروع(').

ويناء على ما تقدم، نرى تقسيم هذا المبحث إلى مطلبين، وذلك على النحو الآتي:

الاملب الأول: التعويض المعادل للضرر.

الاملب الثاني: التعويض العقابي.

(1) Gary Myers, previous reference, P. 1118.

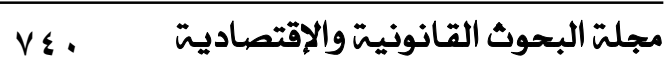




\section{المطاب الأول}

\section{التعويض المعادل للضرر}

تعد وظيفة تعويض المضرور عن الأضرار التي لحقت بـه من جراء الفعل غير

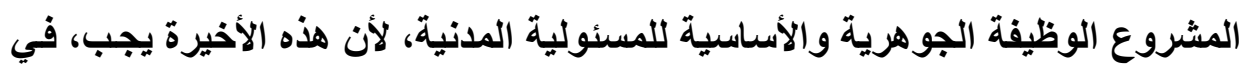
نفس الوقت الذي تهذب فيه السلوك الإنساني، أن تكفل تعويض ضحايا السلوك غيله

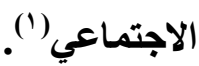

والتعـويض المعسادل للـضرر "Compensatory damages" هـو الــي

يستهدف جبر الضرر الحقيقي أو الفعلي، ويشمل مـا لحق المضرور من خسارة، ومـا

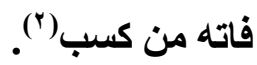

وجدير بالذكر أن جوهر أو أساس المسئولية عن التدخل في العلاقـات التعاقدية يتمثل في الاتتهـاك أو التعدي المتعمد للحقوق التعاقديـة للمـدعي، واللذي يعد أكثر

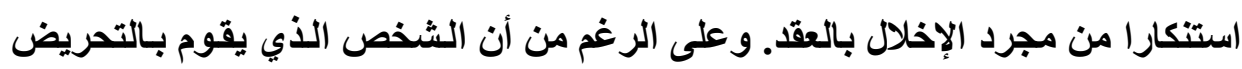

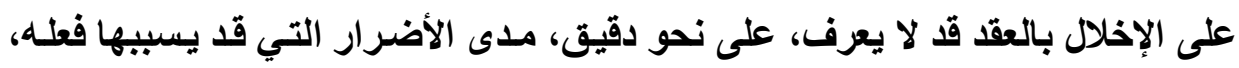

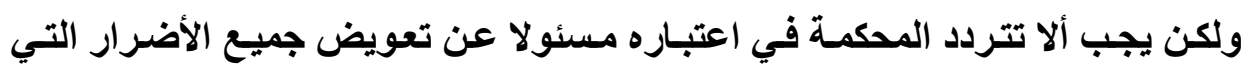

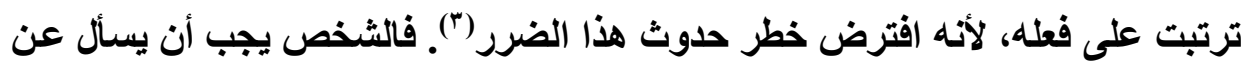

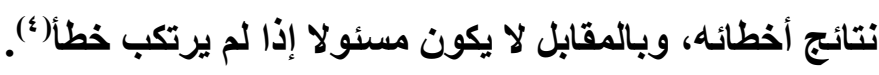
(1) محسن عبد الحميد البيه، حقيقة أزمة المسئولية المدنية ودور تأمين المسئولية، المرجع السابق،

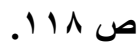

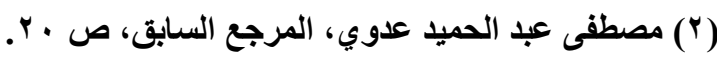
(3) Jerry C. Estes, previous reference, P. 354.

(4) محسن عبد الحميد البيه، حقيقة أزمة المسئولية المدنية ودور تأمين المسئولية، المرجع السابق، 


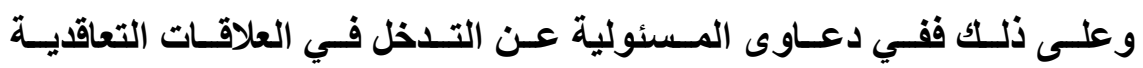

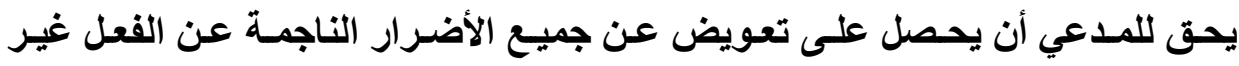

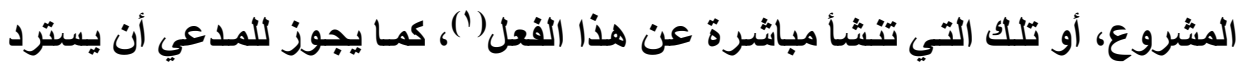

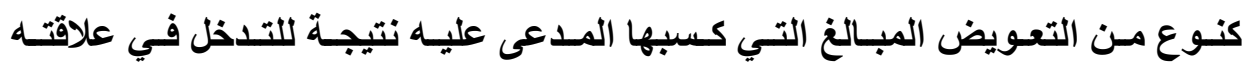

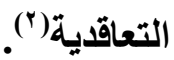

فقد أكلت المحاكم على أن المدعى عليه، الذي قام بالتدخل في العلاقة التعاقدية، يجب أن يكون مسئولا عن جميع الأضرار التي نتجت عن تلخله في العلاقة التعاقية،ة التهاية

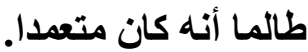

فبموجب الحكم الإنجليزي، (") في قضية Hadley v. Baxendal يقتصر التعويض في دعوى المسئولية العقدية على الأضرار التي من المفترض أن أنكون في

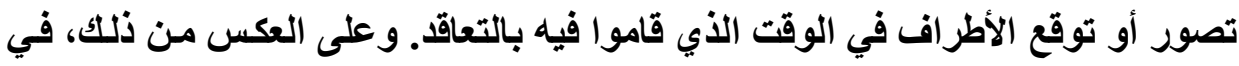

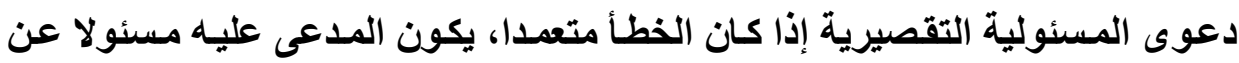
تعويض كل الأضرار التي تنشأ عن فعله.

ولا شـك أنـه لا تطبق معسيير أو أحكام التعويض الخاصـة بـدعوى المسئولية

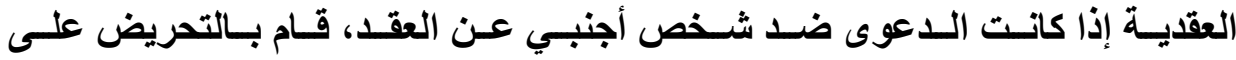

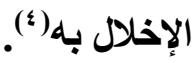

(1) Jerry C. Estes, previous reference, P. 352.

(2) Sandra S. Baron, Hilary Lane, and David A. Schulz, previous reference, P. 1059.

(3) Hadley v. Baxendale, 9 Exch. 341, 156 Eng. Reprint 145, 5 Eng. Rul. Cas. 502 (1854).

(4) Jerry C. Estes, previous reference, P. 353. 
إذن فالمدعي قد يرجع على المتعاقد الذي أخل بالعقد على أسـاس المسئولية

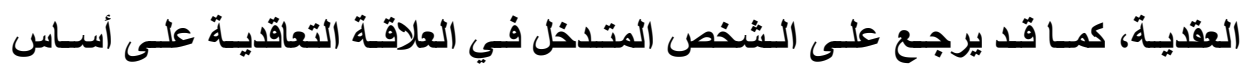
المسئولية التقصيرية، ولكن مـع العلم بأن المسئولية العقدية تختلف عن المسئولية

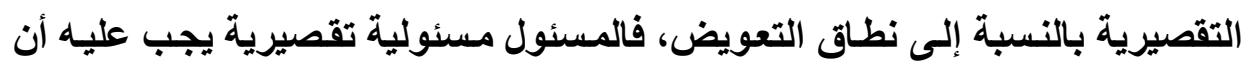

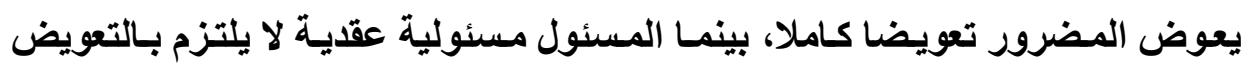

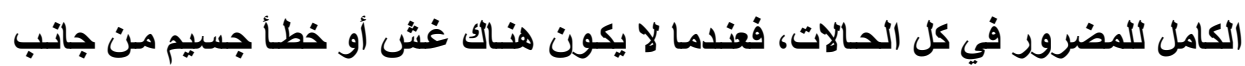

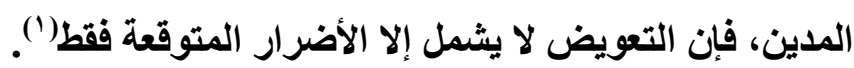

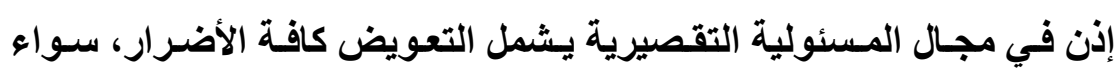

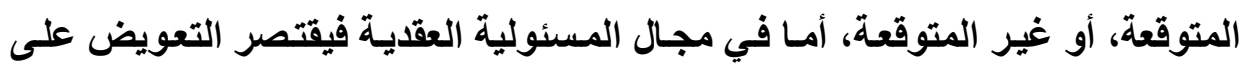

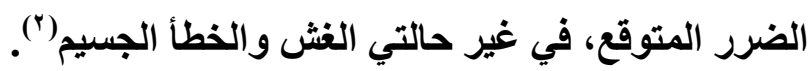

و وعلى ذلك يجوز للمضرور أن يرفع دعوى المسئولية التقصيرية، بعد فشل

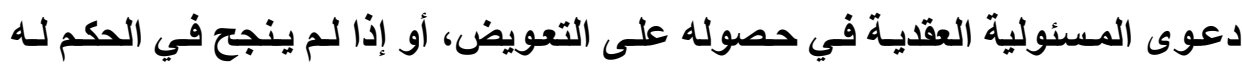

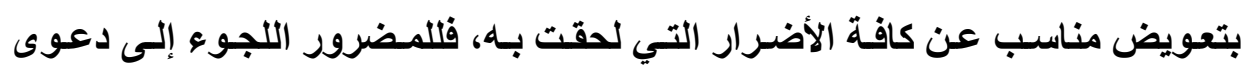

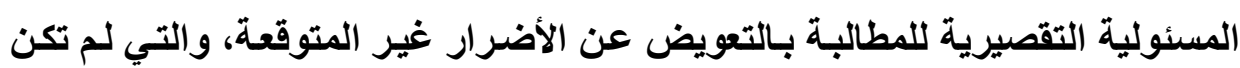

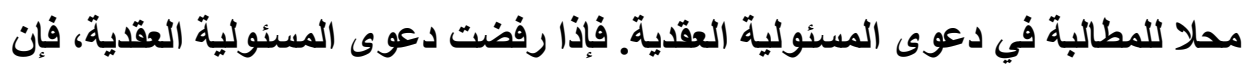

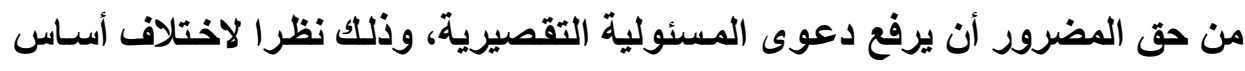

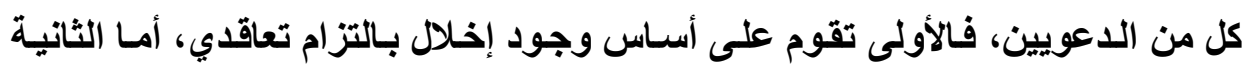

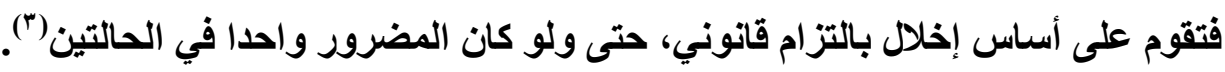


وبناءً على ما تقدم، يبدو أنه لا يوجد أسساس لتطبيق أحكام المسئولية العقدية

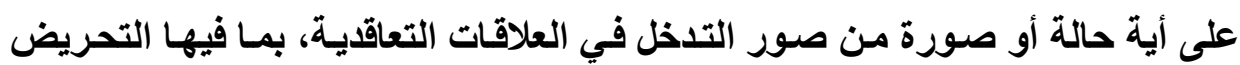

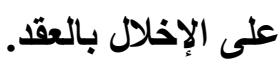

كما تجدر الإثـارة إلى أن أحكام المسئولية العقدية لا يمكن أن تطبق إذا تعلق

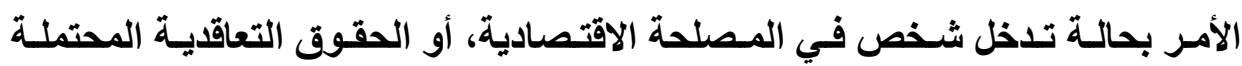

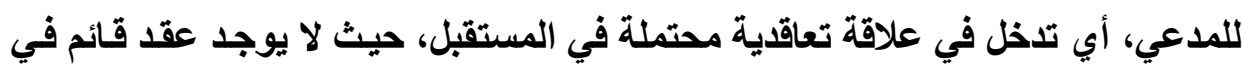

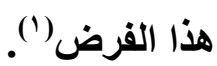

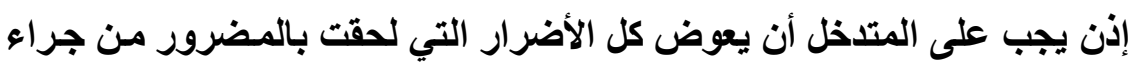
فعله غير المشروع، بشرط أن يكون الضرر مباشرا. ويكون الضرر مباثرا إذا كان التران

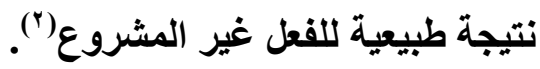

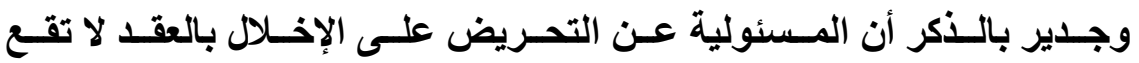

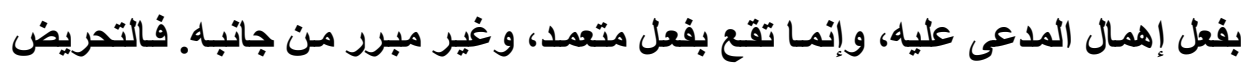

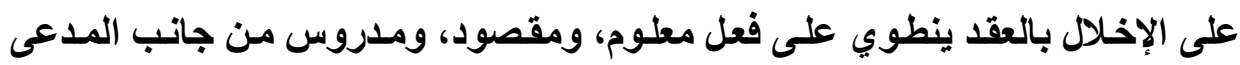

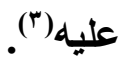

و على ذلك يتعين، عند تحديد وتقدير التعويض، النظر إلى عدة عوامل، أهمها:

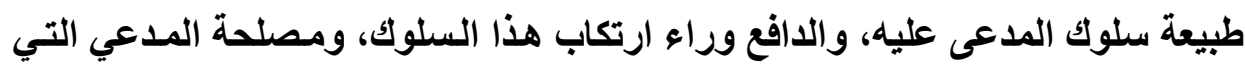

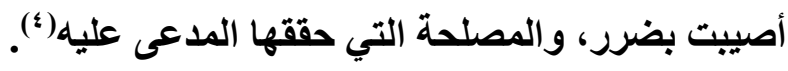

(1) Jerry C. Estes, previous reference, P. 354.

$$
\text { (ץ) عبد الهادي فوزي العوضي، المرجع السابق، ص ه^. }
$$

(3) Jerry C. Estes, previous reference, P. 354.

(4) Gary Myers, previous reference, P. 1111. 
فالأثر الوقائي للمسئولية المدنية يكون واضحا عندما يتمكن المدعي من إثبات

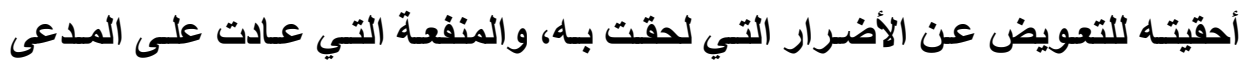

وتجدر الإثارة إلى أن هنـاك حالات يسمح فيها بتعويض الضرر عن التدخل

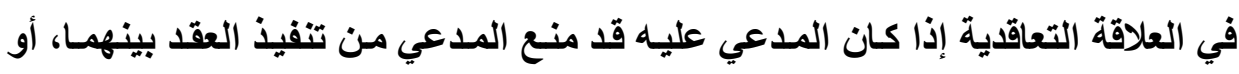

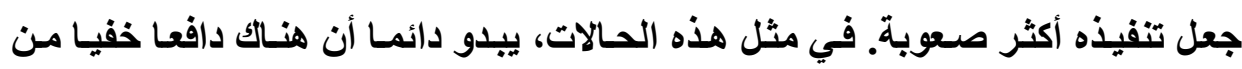

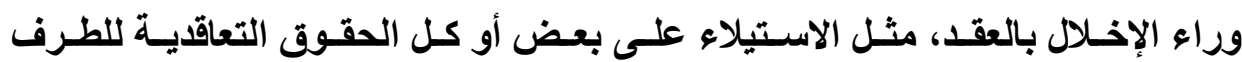
المضرور.

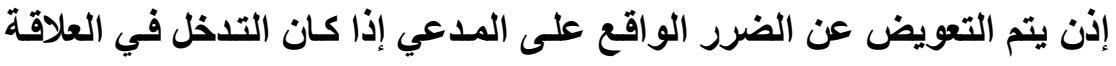

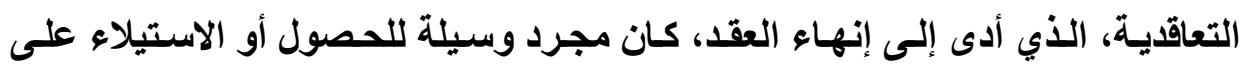

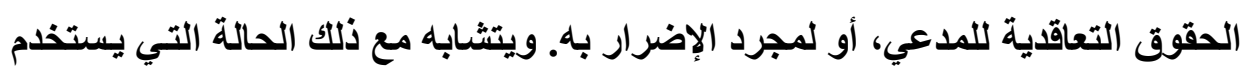

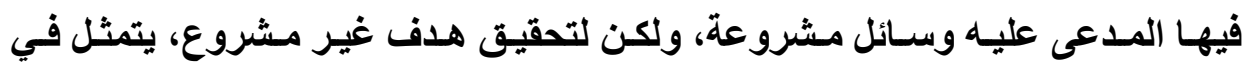
الاستيلاء على الحقوق التعاقدية للمدعي ().

(1) محسن عبد الحميد البيه، حقيقة أزمة المسئولية المدنية ودور تأمين المسئولية، المرجع السابق، $\therefore$. $1 . \wedge$

(2) Jerry C. Estes, previous reference, P. 351, 352. 


\section{المطاب الثاني

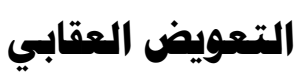

التعويض العقابي أو الجزائي "Punitive damages" هو عقوبة يفرضها

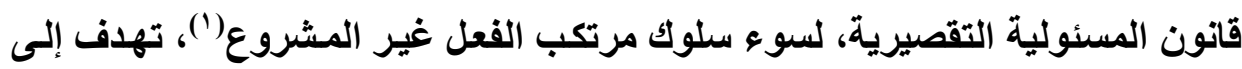

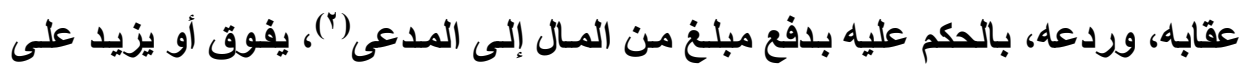

$$
\text { مقدار الضرر الفعلى الواقع عليه("). }
$$

(1) John D. Long, should punitive damages be insured? The Journal of Risk and Insurance, No date, P. 15. "A penalty imposed by tort law for aggravated misconduct". Benjamin C. Zipursky, A theory of punitive damages, Texas Law Review, Vol. 84:105, 2005, P. 105.

(2) Gregory J. Sextro, Note, Corporate insurability of punitive damages arising from employee acts, the journal of corporation law, 2001, P. 103. Amir Nezar, Reconciling Punitive Damages with Tort Law's Normative Framework, The Yale Law Journal, 121:678, 2011, P. 691. Madeleine Tolani, U.S. punitive damages before German courts: A comparative analysis with respect to the ordre public, Annual survey of INT'L and COMP. Law, Vol. XVII, 2011, P. 188.

(3) "Punitive damages are sums awarded to a tort claimant over and above his or her actual harm". Ronen Perry, Economic loss, Punitive damages, And the EXXON Valdez litigation, Georgia Law Review, Vol. 45:409, 2011, P. 438. Thomas H. Cohen, Punitive damage awards in large countries 2001, Civil justice survey of State courts 2001, U.S. department of justice, March 2005, P. 1. Helmut Koziol and Vanessa Wilcox, Punitive damages: Common law and civil law perspectives, Springer Wien New York, Tort and insurance law, Vol. 25, April 2009, P. 7. Madeleine Tolani, previous reference, P. 188. 


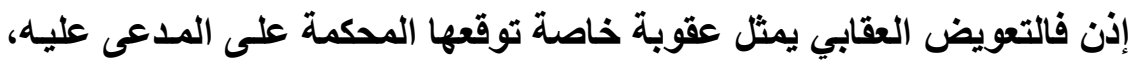

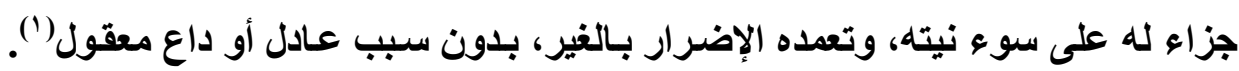

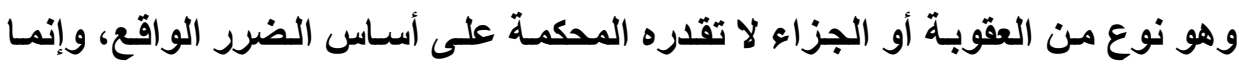
على أساس سوء نية الفاعل، بإرادة الفعل ونتيجته(ب).

وعلى ذلك فللتعويض العقابى وظيفتان أساسيتان، الأولى: وظيفة العقاب، وهى

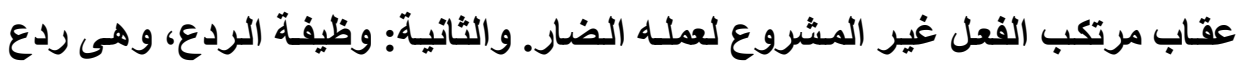

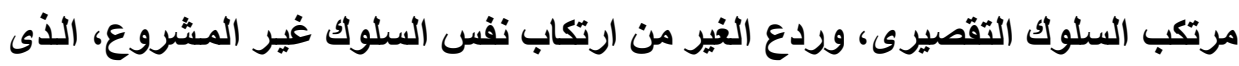
يحدث الضرر للآخرين فى المستقبل (").

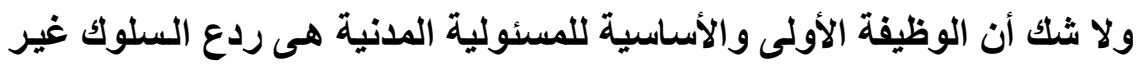

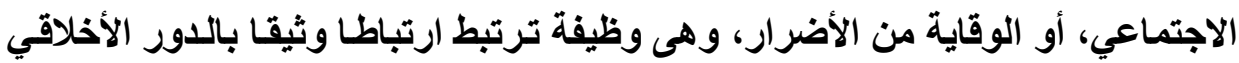

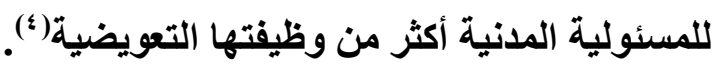

فمن الممكن للكم الذي يصدره القاضي في دعاوى المسئولية التقصيرية ألا

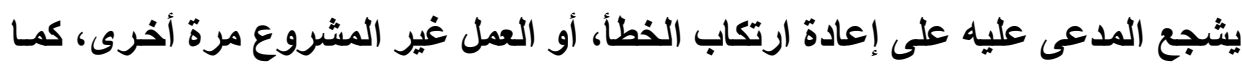

$$
\begin{aligned}
& \text { (1) مصطفى عبد الحميد عدوي، المرجع السابق، ص V V؛. }
\end{aligned}
$$

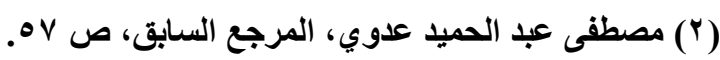

(3) Amir Nezar, previous reference, P. 691. Jill Wieber Lens, Procedural due process and predictable punitive damage awards, Brigham Young University Law Review, 2012, P. 3. Catherine M. Sharkey, The future of class wide punitive damages, University of Michigan Journal of Law Reform, Vol. 46:4, 2013, P. 1131.

(ع) محسن عبد الحميد البيه، حقيقة أزمة المسئولية المدنية ودور تأمين المسئولية، المرجع السابق، 
يمكن أن يمثل تحذيرا لغيره مـن الأشـخاص مـن ارتكـاب نفس الأفعـال الخاطئسة غير

وعلى ذلك متى تقررت المسئولية التقصيرية للمتدخل في العلاقة التعاقدية، تقوم

معظم المحاكم بمنح المدعي المضرور تعويضات تغطي كل أنواع الأضر ار التي وقعت عليه بسبب تلاخل المدعى عليه في العلاقة التعاقدية، فهي تعوضه عن الأضرار الفعلية التي أصابته، بالإضافة إلى منحه تعويضات عقابية، تفوق أو تزيل عن الضرر الفعلي،

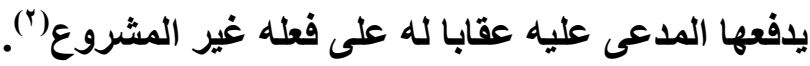
ففي دعوى المسئولية عن التـدخل في العلاقـات التعاقديـة سـواء عن طريـق التحريض على الإخـلال بالعقد، أو عن طريـق أيسة وسيلة أخرى، يجـوز للمـدعي أن

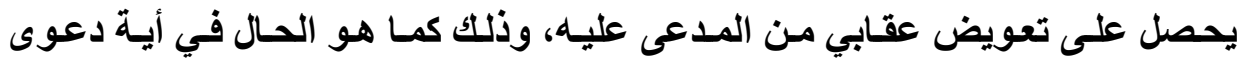

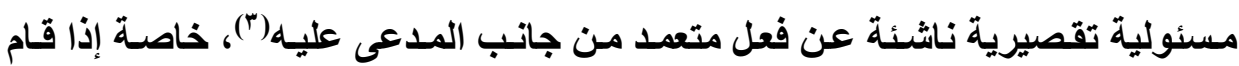
بالتدخل في العلاقة التعاقدية عن طريق استخدام وسـائل غير مشروعة، أو كسان الدافع مئع وراء هذا التدخل غير مشروع.

(1) James M. Underwood, Road to nowhere or jurisprudential U-Tern? The intersection of punitive damage class actions and the due process clause, 66 Wash. And Lee Law Review 763, 2009, P. 806.

(2) Gary Myers, previous reference, P. 1118.

(3) Sparks v. McCrary, 156 Ala. 382, 47 So. 332 (1908); Guillory v. God 134 Cal. App. 2d 628, 286 P.2d 474 (1955); Dunshee v. Standard Oil Co., 152 Iowa 618, 132 N.W. 371 (1910). See also, Yu Yamazaki, Preliminary agreements as contracts: facilitating socially desirable transactions using the doctrines of injunction, disgorgement, and tortious interference, New York University Journal of Law and business, Fall 2012, P. 18. 
وجدير بالذكر أن بعض المحاكم تحكم على المدعى عليه بدفع تعويض عقابي،

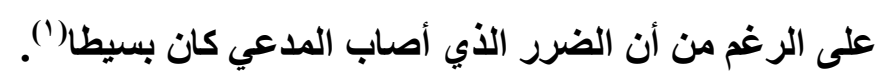

ويرى البعض أنه من الأفضل، متى كان ذلك ممكنا أو مناسبا، أن يحكم على التى

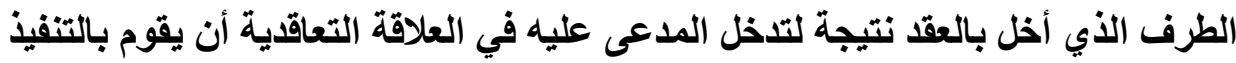

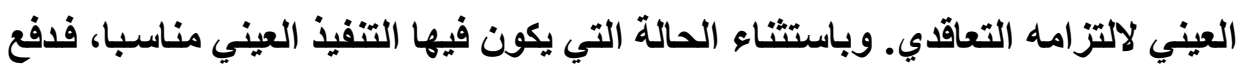
المدعى عليه للتعويض العقابي سيكون رادعا لمثل هذه الأفعال غير المشروعة. لأنئ.

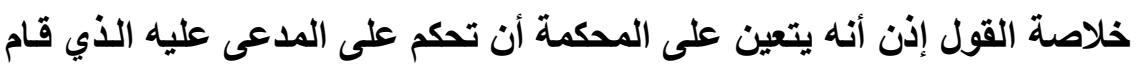

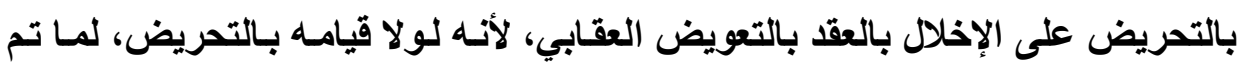

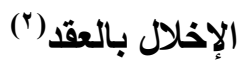

(1) Sandra S. Baron, Hilary Lane, and David A. Schulz, previous reference, P. 1061.

(2) Gary Myers, previous reference, P. 1120. 


\section{المبحث الثاني \\ حالات الإعفاء هن المسئولية التقصيرية عن التدخل في \\ العلاقات التعاقدية}

يشكل المبرر أو العذر المشروع الدفاع الأساسي لاعوى المسئولية التقصيرية

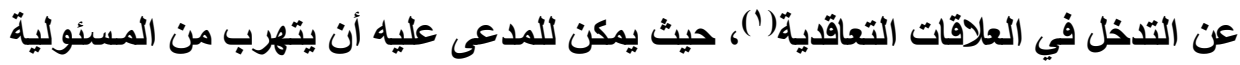

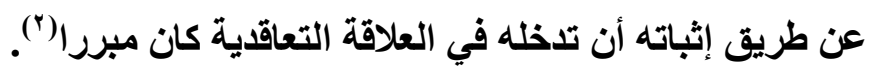

فبإن مسألكة تبرير التدخل في العلاقة التعاقديـة هـي دفاع إيجـابي، وإن الأمـر

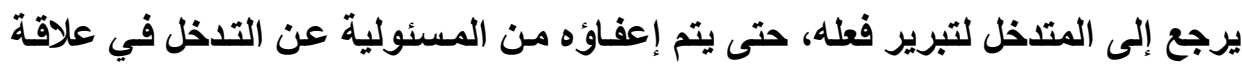

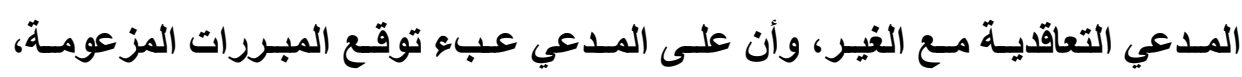

وضحدها منذ البداية(").

وجدير بالذكر أن العذر أو المبرر الذي يعفي المدعى عليه من المسئولية عن

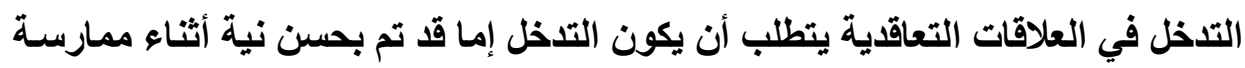

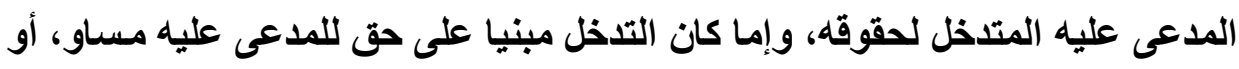

يفوق حق المدعي المضرور (؛).

(1) Jerry C. Estes, previous reference, P. 358.

(2) If the interference is prima facie tortious, then to escape liability the defendant must convince us with something like the following: "My violation of an existing contract right was justified because I sought to further my own economic interest". Clark A. Remington, previous reference, P. 667.

(3) Jerry C. Estes, previous reference, P. 344.

(4) James B. Sales, previous reference, P. 147. 
فالمبدأ العـام بشأن المبرر أو العذر المعفي مـن المسئولية عن التـخل في التئي

العلاقات التعاقدية هو أن الثخص يعفى من المسئولية عن التذخل في العلاقة التعاقدية

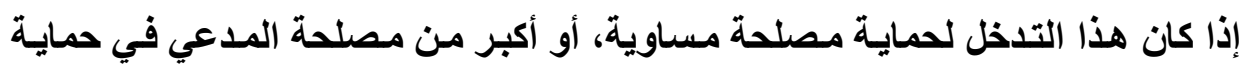

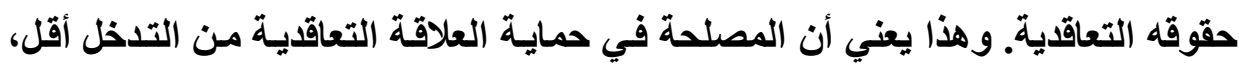

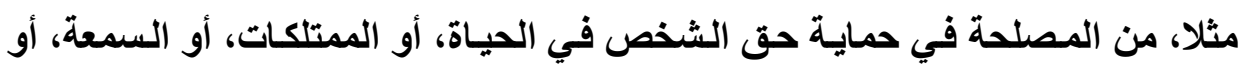

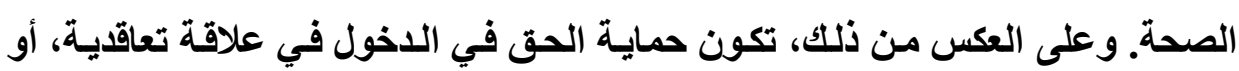

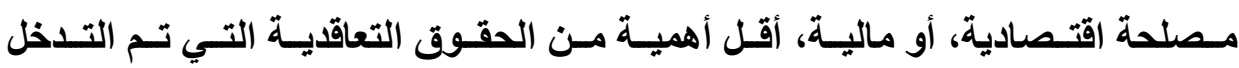

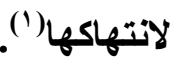

إذن يتعين النظر أو البحث عن مدى وجود مبرر للتدخل في العلاقة التعاقدية،

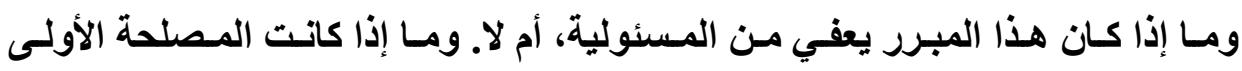

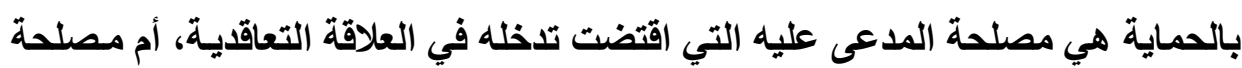
المدعي، أو حقوقه التعاقدية.

و وعلى ذلك يجب على المحاكم أن تحدد السلوك المبرر لفعل التدخل في العلاقة

التعاقدية، لتقرر ما إذا كان سيتم إعفاء المدعى عليه من المسئولية، أم لا. أما إذا لم يكن هناك مبرر أو هدف من التذخل في العلاقة التعاقدية، أو كان هذا

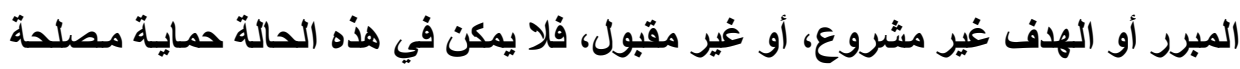

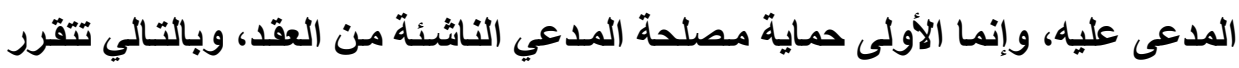

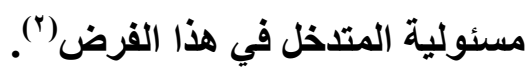

(1) Charles E. Carpenter, previous reference, P. 763.

(2) Charles E. Carpenter, previous reference, P. 745, 746. 
ولا شكك في أن استخدام المدعى عليه لوسـائل غير مشروعة، أو ضسارة عند

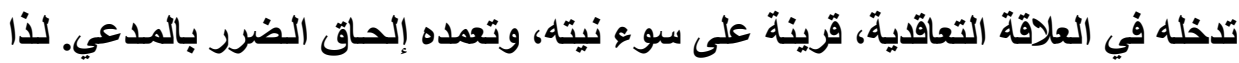

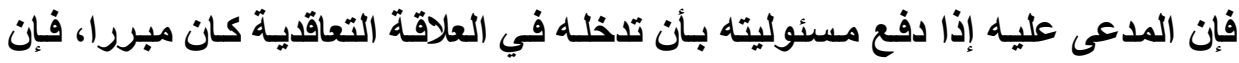

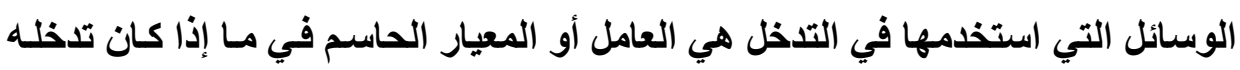

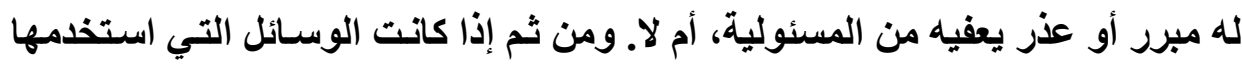

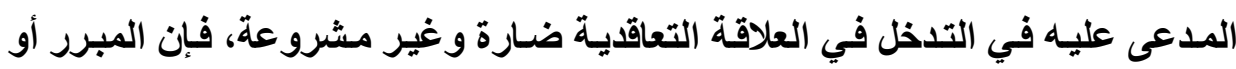
العذر الذي يدفع به مسئوليته لن يقبل (') التهل

لذا يتعين على المدعي أن يثبت أن المدعى عليه قد تعدـ التدخل في العلاقة التعاقدية، ويتحول عبء الإثبات إلى المدعى عليه، الذي يتعين عليه إثبات العذر أو الو التواعيه

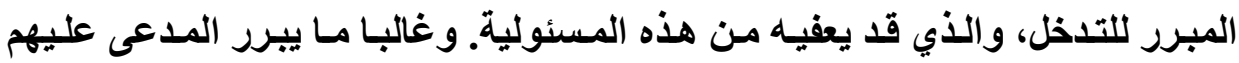

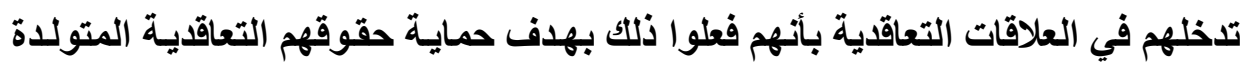

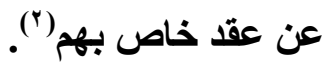
وتجدر الإثـارة إلى أنه لا يعد دفاعا، ينفي المسئولية عن المدعى عليه في

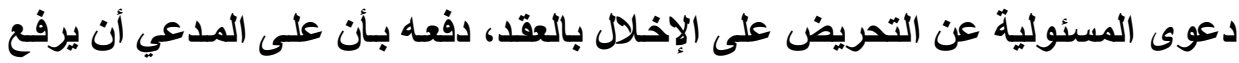

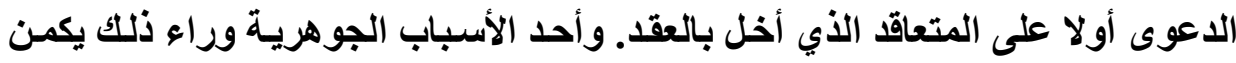

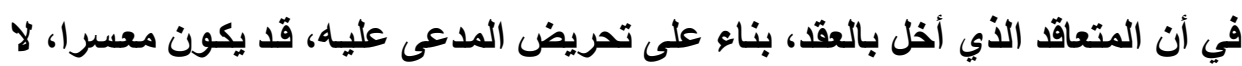

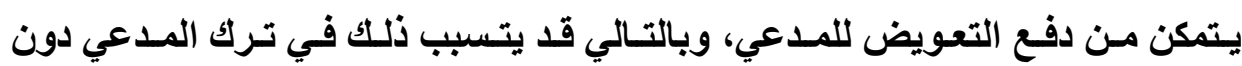

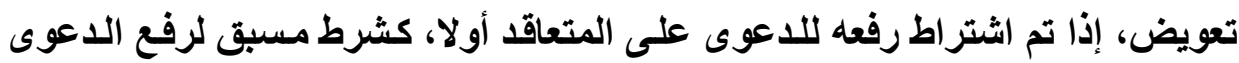

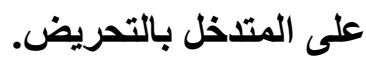

(1) Jerry C. Estes, previous reference, P. 347.

(2) Gary Myers, previous reference, P. 1110. 


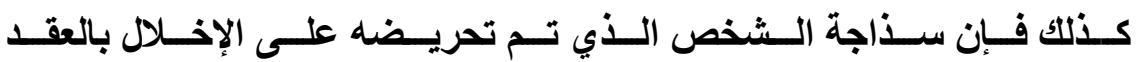

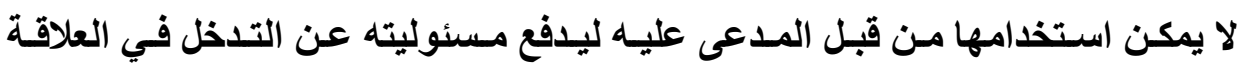

أيضا فإهمال الددعي المضرور لا يعفي المدعى عليه من المسئولية عن التدخل

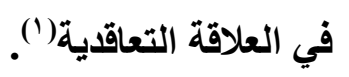

ويجدر التنويه إلى أنه إذا كان الدافع وراء التنخل في العلاقة التعاقدية سيئا، أي

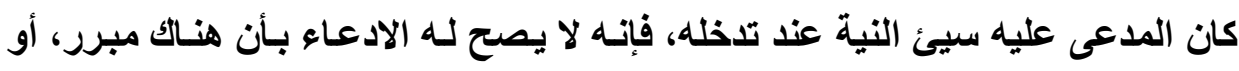

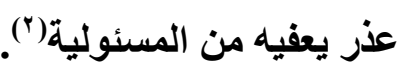

وأخيرا إذا أثبت المدعى عليه أن الضرر لم يكن راجعا إلى خطئه تنتفى علاقة

$$
\text { السببية، ومن ثم يتخلص من المسئولية("). }
$$

وفيما يلي نتناول أهم المبررات، أو الأعذار المشروعة التي تعد سببا في إعفاء المدعى عليه من المسئولية التقصيرية عن التدخل في العلاقة التعاقدية: ا - تدخل المدعى عليه في العلاقة التعاقدية لحماية هصلحته التعاقدية: قد يتلخل شخص في علاقة تعاقدية للغير بهدف حماية علاقة تعاقدية خاصة به، أي حماية مصلحته التعاقدية.

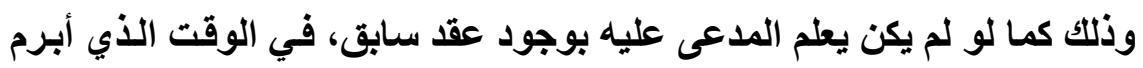

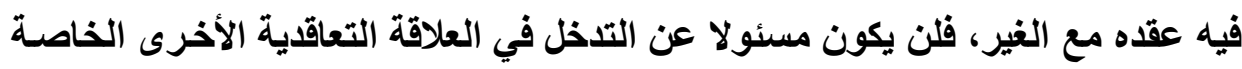

(1) Jerry C. Estes, previous reference, P. 357, 358.

(2) Charles E. Carpenter, previous reference, P. 745, 746.

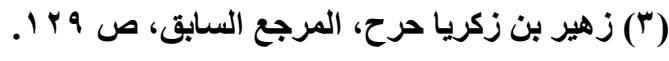


بالمدعي، إذا قام بتففيذ عقده هو، على الرغم من أن تنفيذ المدعى عليه لعقده، سيترتب عليه استحالة تنفيذ عقد المدعي.

وذلك كما لو باع شخص سلعة معينة لثخصين، فإنه إذا قام بتنفيذ عقده بالنسبة

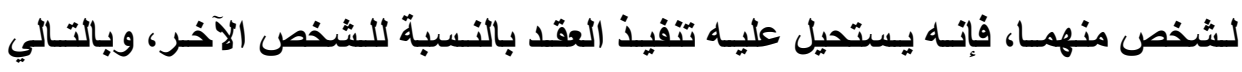

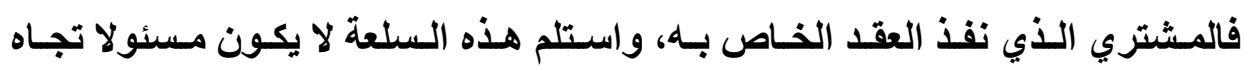
المشتري الآخر، الذي كان سببا في عدم تنفيذ عقده مع البائع (')

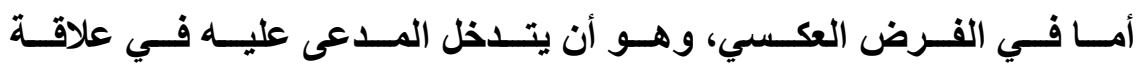
تعاقدية لثخص، وهو على علم بأن هذا الشخص بينه وبين المدعي عقد قائم سـابق،

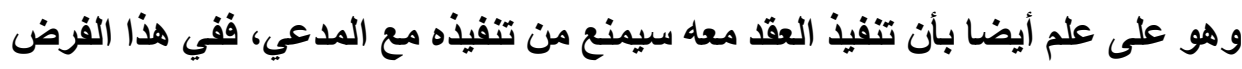

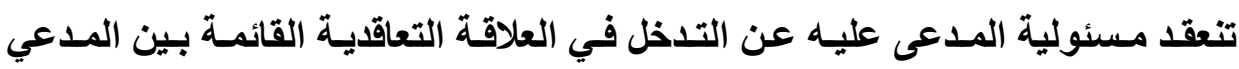
و والغير.

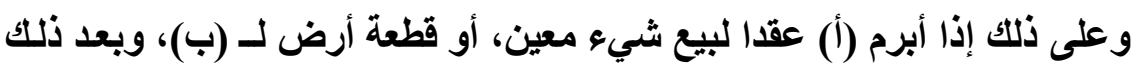

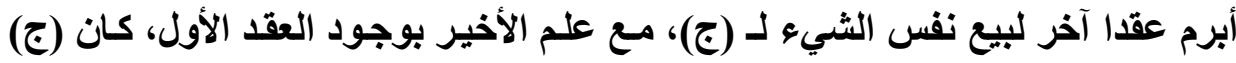

(1) Read v. Friendly Society 2 K. B. 88, 95 (1902), It was said: "It may well be that a person, or many persons acting in concert, would have a right to demand the fulfillment of a contract entered into with him or them, even though such fulfillment involved him who performed it in breaking a contract made by him with another person. Many examples may be put, for instance, a man who had affected to sell the same article to two separate purchasers could not possibly perform one contract without breaking the other, If both insisted on their rights, yet it could not render the purchaser, who insisted on his contractual rights, liable at the suit of the other purchaser". 
مسئولا عن التخل في العلاقة التعاقدية بين (أ) و (ب)، إذا حرض (أ) على نقل الثيء،

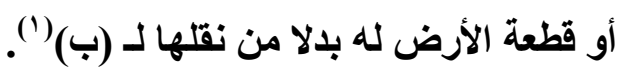

إذن يجب أن يقع التـدخل في العلاقـة التعاقديـة، أو انتهـاك الحقوق التعاقديـة للمـدعي بحسن نيـة، بغرض حمايـة مصلحة المـدعى عليـه أو حقوقهـ. أمـا إذا لـم يـتم التدخل على هذا النحو، فلن يعفى المدعى عليه من المسئولية عن التدخل في العلاقة التعاقدية الخاصة بالمدعي( (`). فقي قضية(") بين Jones v. Leslie، ترك المدعي العمل عند المدعى عليه،

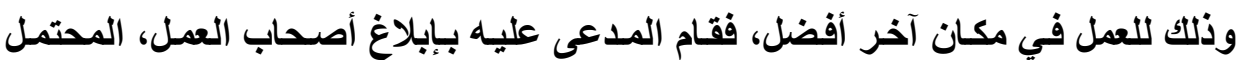
تعاقدهم مع المدعي، بأنهم إذا قاموا بتثغيل المدعي، فإنه سيحرمهم من تجارتـه. فحكم في هذه القضية بأن تلخل المدعى عليه في العلاقة التعاقدية الخاصة بالمدعي كان غير باله مبرر، مما يجعله مسئولا تجاه المدعي، وعليه دفع تعويض عن الأضرار التي وقعت لـه له

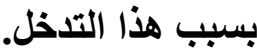

r- تدخل المدعى عليه في العلاقة التعاقدية لحماية الحق في الحيساة أو السسمعة أو الصحة:

إن القانون يسمح بالتدخل في العلاقة التعاقدية، ولا يرتب عليه مسئولية، متى كـان هذا التـلخل مبررا، أو تـم بحسن نيـة لحمايـة حق المـدعى عليـه في الحيـاة، أو

(1) Charles E. Carpenter, previous reference, P. 747.

(2) The invasion of the plaintiff's interest must be done in bona fide protection of the defendant's interest. It will not be a justification if it is done out of spite. Charles E. Carpenter, previous reference, P. 761.

(3) Jones v. Leslie, 61 Wash.107, 112 Pac. 81 (1910). 
السمعةة، أو الـصحة، أو الملكيـة، أو لحمايـة المجتمعِ، متـى كانـــ هـذه الحمايـة أو المصلحة أولى وأهم من حماية مصلحة المدعي الناشئة من العقد.

فلا شكك في أن المصلحة، أو الحق في الحيـاة، أو السمعة، أو الملكية تخضع للحماية من الانتهاك، أو الاعتداء بصورة أكبر وأولى من حماية حقوق المتعاقد الناشئة

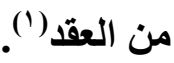

وعلى ذلك إذا كان تلخل المدعى عليه في العلاقة التعاقدية بين المدعي والغير لازما لحماية الحقى في الحياة، أو السمعة، أو الصحة فإنه لا يسأل عن هذا التدخل تلجهاه المدعي.

فمتى قام المدعى عليه، بحسن نية، وعلى نحو معقول، بتحريض أو دفع شخص للإخلال بعقد ما، إذا كان في تنفيذه ما يهدد صحته، فإنه لا يسأل عن ذلك. وتطبيقا لذلك، في قضية(؟) بين Legris v. Marcotte قامت أم لأولاد، كانوا

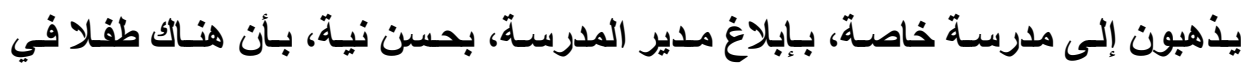
المدرسة يعاني من مرض خطير ومعد، مما دفع مدير المدرسة إلى فسخ عقده مـع والـ

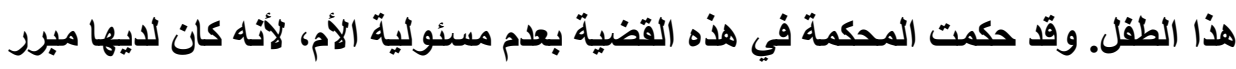

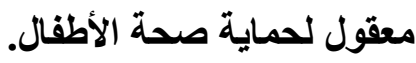

إذن متى كان أمامنا مصلحتان، الأولى مصلحة المجتمع في حمايـة الحق في

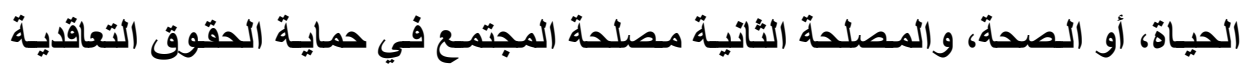
للفرد، كان الأولى والأجدر بالحماية هي المصلحة الأولى، بشرط أن يكون الدافع وراء

(1) Charles E. Carpenter, previous reference, P. 745, 746.

(2) Legris v. Marcotte, 129 Ill. App. 67 (1906). 
التضحية بمصلحة المدعي في حماية حقه التعاقدي حسن النية، وبالقدر الضروري فقط

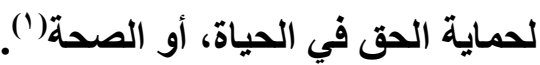

\section{r- تدخل المدعى عليه في العلاقة التعاقدية لإعطاء النصيحة:}

إن الشخص المسئول عن شـئون شـخص آخر لـه مبرر، أو عذر يعفيه مـن

المسئولية إذا قام بنصحه بعدم الاخول، أو عدم استكمال علاقة تعاقدية مـع الغير. وهذا مثال من الأمثلة القليلة التي يمتد فيها العذر الذي يعفي من المسئولية إلى النصيحة

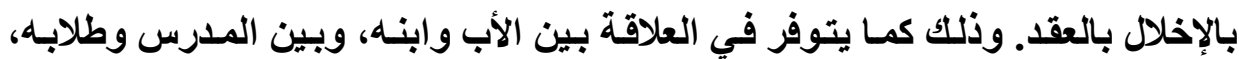
وبين المحامي وعملائه، وبين العاملين في البنك والمستثمرين. ويشترط، حتى يعفى ولإنى مقدم النصيحة من المسئولية عن التدخل في العلاقات التعاقدية، أن تكون هذه النصيحة مطلوبـة منـه، وليس هو الذي قدمها مـن تلقـاء نفسـه، كمـا يجب أن يقـدم النصيحة بأمانة (r) مبوده

أيضا لموظفي الثركات، أو مديريها مبرر، أو عذر يعفيهم من المسئولية إذا

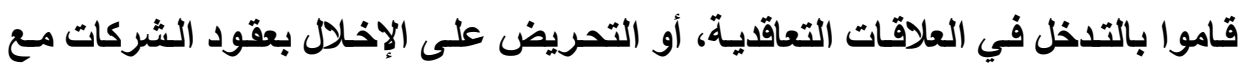

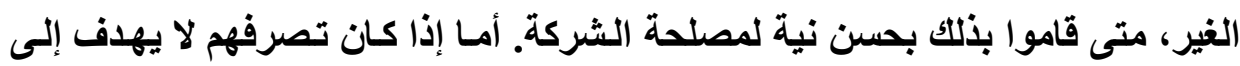

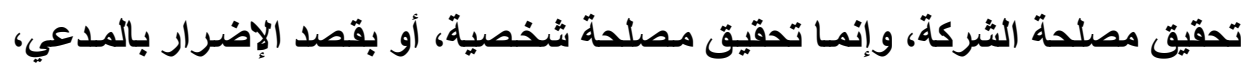
فإن ذلك ينشئ مسئوليتهم الشخصية"("). فـلا شـكـ أن هنـاك فرقـا واضـحا بـين التحريض على الإخـلال بالعقد، وبـين النصيحة بالإخلال بالعقد، حيث يتضمن التحريض على الإخلال بالعقد خلق المدعى عليه

(1) Charles E. Carpenter, previous reference, P. 749.

(2) Jerry C. Estes, previous reference, P. 361. Clark A. Remington, previous reference, $P .653$.

(3) Jerry C. Estes, previous reference, P. 362. 
لأسباب جديدة، ليست موجودة، تدفع المتعاقد على الإخلال بعقده، أما النصيحة تتضمن قيام الشخص بتنبيه المتعاقد لأسباب موجودة بالفعل، تدفعه لنصيحته بأنه من الأفضل أن يتحلل من هذا العقد (').

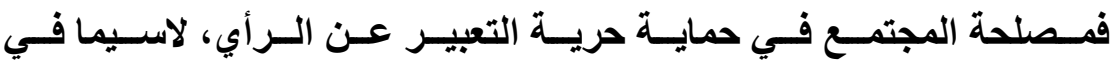

إعطاء النصيحة متى طلب ذلك، جديرة بالحماية. وعلى ذلك متى طلب المتعاقد من شخص إعطاءه النصيحة والرأي فيما يتعلق بالعقد، فنصحه بأن من مصلحته أن يفسخ العقد، ممـا دفع المتعاقد فعـلا للقيـام بـذلك، ففي هذا الفرض لا يكون المـدعى عليـه

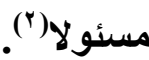

إذن فالإخلال بالعقد التالي لنصيحة المدعى عليه لا ينشئ مسئولية الأخير عن

التخخل في العلاقة التعاقدية.

وعلى ذلك فالنصيحة التي يقدمها خبير، أو شـص مهنـي محترف، بحسن

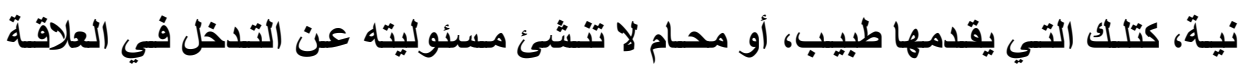
التعاقدية.

وعلى العكس من ذلك، إذا لم يكن المدعى عليه حسن النية في تقديم النصيحة،

و إنما كان يهدف إلى الإضرار بالمدعي، عن طريق التدخل للإخلال بعلاقته التعاقدية،

فإن المدعى عليه يكون مسئولا عن تعويض المدعي المضرور (").

(1) Jeanette Andersson, previous reference, P. 8.

(2) In Walker v. Cronin, where the defendant was held liable for inducing an employee to leave the plaintiff's employment, it was said, "This decision does not apply to a case of interference by way of friendly advice, honestly given; nor is it a denial of the right of free expression of opinion". Walker v. Cronin, 107 Mass. 555, 566 (1871).

(3) Charles E. Carpenter, previous reference, P. 749. 


\section{§- تدخل المدعى عليه في العلاقة التعاقدية بهدف المنافسة المشروعة:}

يشترط في الإخلال بالواجب الذي يرتكبه الفاعل أن يكون غير مشروع، فباذا

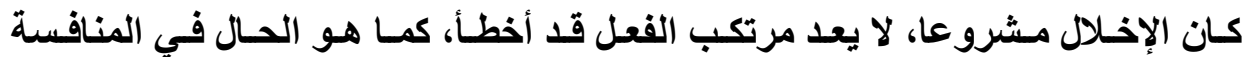

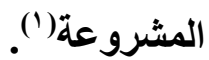

ويعد العذر أو المبرر الخاص بالمنافسة المشروعة هو الدفع الأكثر شيوعا، والذي عن طريقه يعفى المتدخل مـن المسئولية التقصيرية عن التدخل في العلاقة التحنة

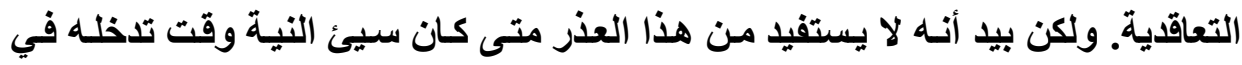

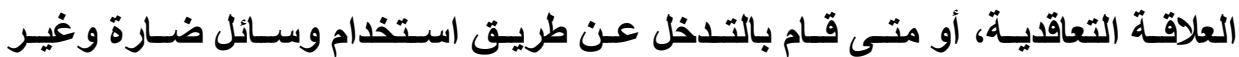

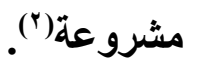

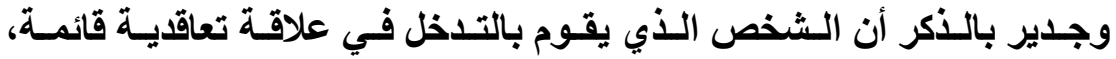
ومستقرة، وصحيحة، ينظر إليه على أنه مرتكب فعل غير مشروع وضـار، حيث يدل

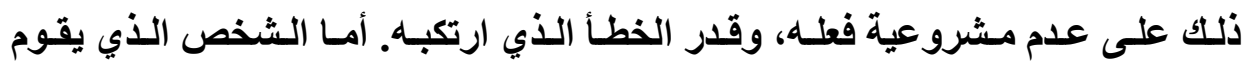

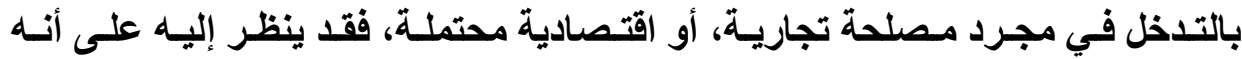
منافس، وطبقا للنظام الاقتصادي يعتبر أنه قد قام بهذا الفعل على أساس مبدأ المنافسة الفئة الحرة المشروعة، ومن ثم لا يتعين اعتبار المتتافس مسئولا إذا قام بالسعي للحصول

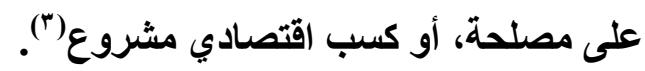

فالأطراف الذين يمارسون عملا تجاريا دون إبرام عقد صحيح فيما بينهم، أي الذين لايهر فقط مجرد أمل محتمل في الدخول في علاقة تعاقية، لابد أن يقبلوا أنهم

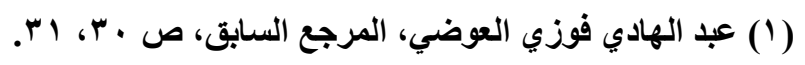

(2) Jerry C. Estes, previous reference, P. 359.

(3) Gary Myers, previous reference, P. 1121, 1122.

VY . 
أكثر عرضة لتدخل المنافسين للحصول على مكاسب مالية لهم، وبمعنى آخر أن القانون يحمي، بصورة أكبر، المتعاقدين من تـخل الشخص الثالث إذا كـان هنـاك عقد قـائم وصحيح، أمسا إذا كـان هنـاك مجرد احتمـال للاخول في علاقة تعاقديـة مستقبلية، فبان القانون يسمح بمدى أكبر من إمكانية تلذخل الغير بغرض المنافسة(') ويلاحظ أن مجرد كون المـدعى عليـه كمنـافس لا يعفيـه مـن المسئولية عن

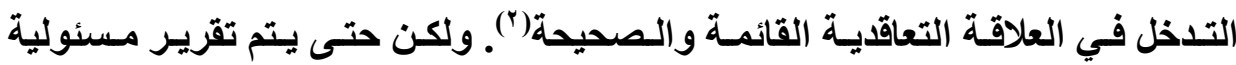
المنافس، إذا قام بالتدخل في العلاقة التعاقديـة الخاصـة بمنافسه، فهنـاك ثلاثة اتجاهـات في هذا الثأن: الأول: بعض الولايات تتطلب من المدعي أن يقوم بإثبات قيام المدعى عليـه باسـتخدام وسـائل غير مشروعة أو ضسارة، كالتعدي، أو الغش عند تلخذله في

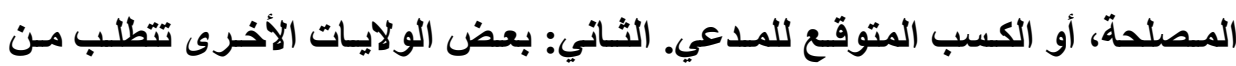

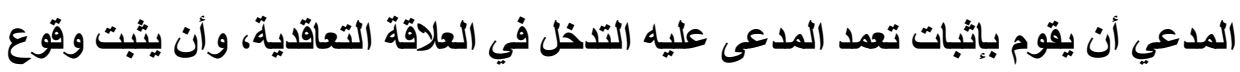
ضرر لله، ومن ثم يتم نقل عبء الإثبات على المدعى عليه لتبرير التدخل. الثالث: ولايات كثيرة تتطلب من المدعي أن يقوم بإثبات، ليس فقط التدخل المتعمد والضرر، وإنما أيضا أن تلخل المدعى عليه كان غير مشروع، أي غير مبرر ("). وجدير بالذكر أنـه عندما يكون التـدل في العلاقة التعاقديـة حادثا عرضيا، وغير مباشر نتيجة لأفعال المدعى عليه، التي قام بها بغرض تحقيق مصلحة اقتصادية

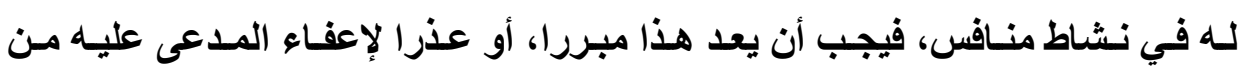
المسئولية عن التدخل في العلاقات التعاقدية.

(1) James B. Sales, previous reference, P. 136. Alex B. Long, previous reference, P. 4.

(2) James B. Sales, previous reference, P. 130.

(3) Gary Myers, previous reference, P. 1122, 1123. 
كنلك عندما يكون التذخل في العلاقة التعاقدية ناتجا عن إهمال المدعى عليه،

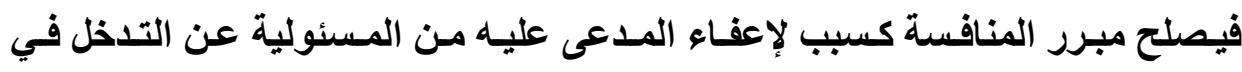

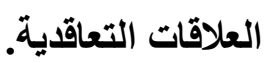

وعلى ذلك، فلا يمكن اعتبار (أ) مسئولا عن التذخل في العلاقة التعاقدية إذا قام

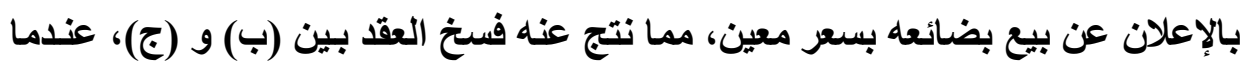

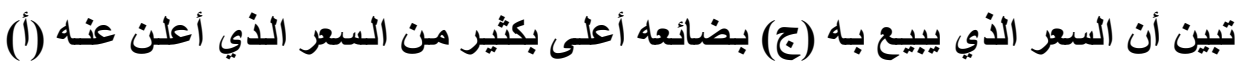

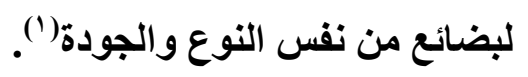
بل يذهب القانون إلى أبعد من ذلك، حيث يسمح بمبرر المنافسة للإعفاء من

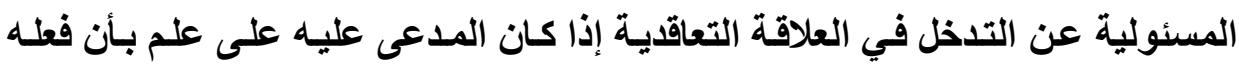

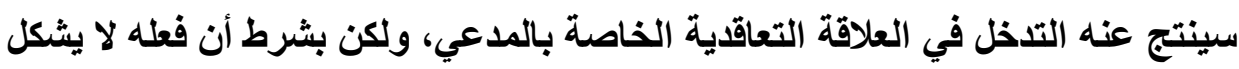

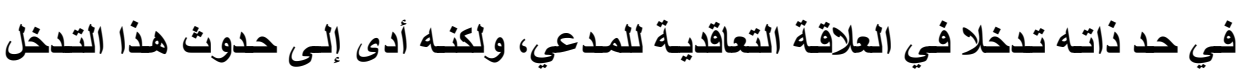

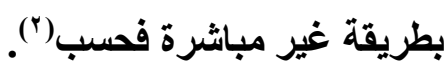

في قضية(") بين Passaic Print Works v. Ely and Walker Dry Goods Company تتلخص وقائع هذه القضية في أنـا بعد أن حصل المدعى عليه

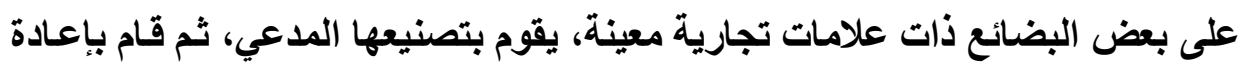

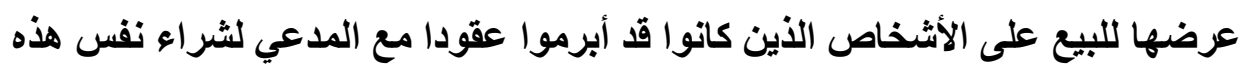

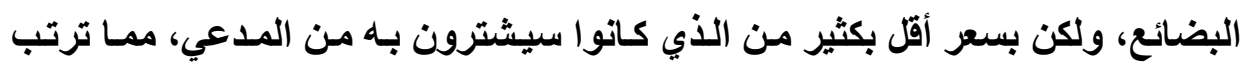

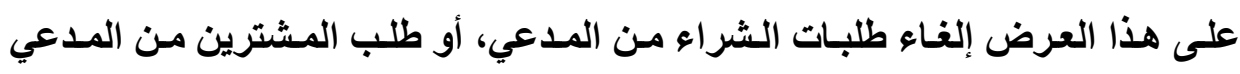

(1) Charles E. Carpenter, previous reference, P. 758.

(2) Charles E. Carpenter, previous reference, P. 759.

(3) Passaic Print Works v. Ely and Walker Dry Goods Company, 105 Fed. 163 (C. C. A. 8th, 1900). 
استرداد جزء من المبلغ المدفوع، أو أن يحصلوا على خصم من المبلغ الذي تعاقدوا

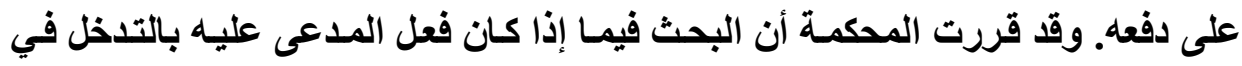

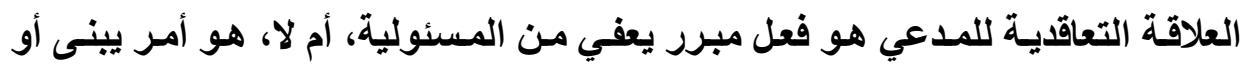

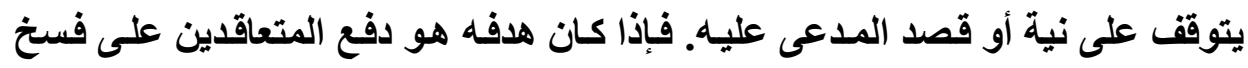

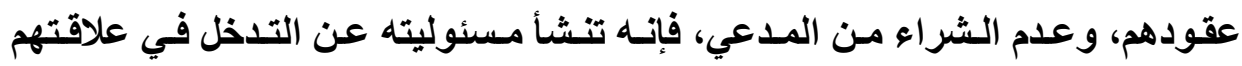
التعاقدية، ويتعين عليه تعويض المدعي عن الأضرار التي لحقته من جراء هذا التدخل. أما إذا كان المدعى عليه حسن النية، حيث كان يقصد التخلص من هذه البضائع ببيعها

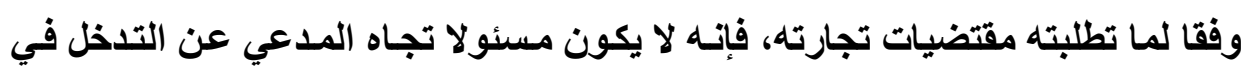
علاقته التعاقدية. وتجــر الإشـارة إلى أن المنافسة المسشروعة، كدفع، أو مبـرر للإعفــاء مـن المسئولية، يقتصر على المتنافسين فقط. وبالتالي فالمدعى عليه يجب أن يكون منافسا للمدعي في النشاط الأي أوقع فيه المدعى عليه ضررا على المدعي. إذن فلا يكفي أن يكون للمدعى عليه مصلحة متعارضة مـع مصلحة المدعي.

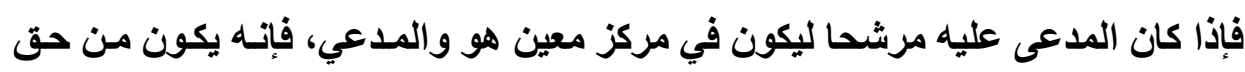
المدعى عليه أن يقتع صاحب العمل لفصل المدعي، وتشغيله مكانه.

ولكن إذا كانت مصلحة المدعى عليه تختلف وتتميز عن مصلحة المنافس في

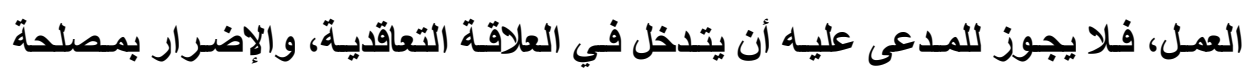
المدعي، أو حقوقه التعاقدية) (') وفي هذا الخصوص يعد العامل في بيعه لعمله، وصساحب العمل في شرائه لـه،

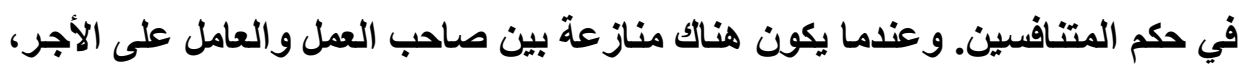

(1) Charles E. Carpenter, previous reference, P. 759. 
أو ساعات العمل، أو شروط التثغيل، فكل طرف يحق له أن يتدخل في العلاقة التعاقدية

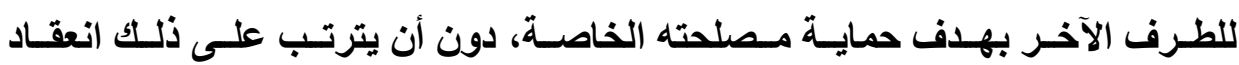

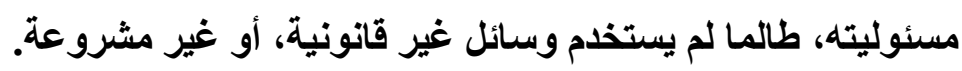

وعلى ذلك فرفع أو تحريض صاحب العمل على فصل العمال عن طريق وسيلة

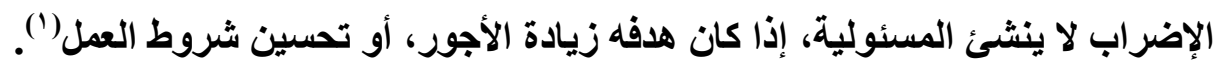
إذن يتضح مما قدمنا أن المنافسة المشروعة تعطي الحق، أو المبرر للتدخل

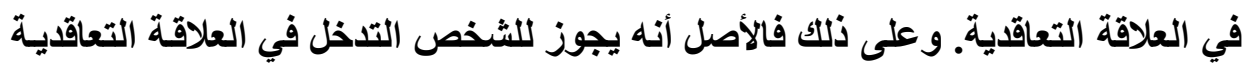

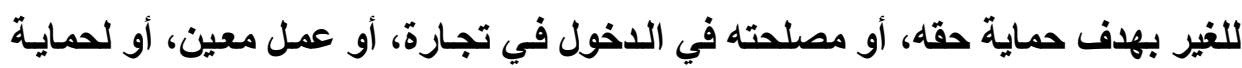

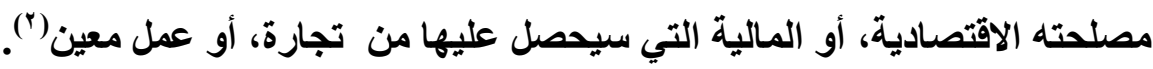
ولكن هناك أربع حالات يكون فيها التدخل في العلاقة التعاقدية غير مبرر على التى

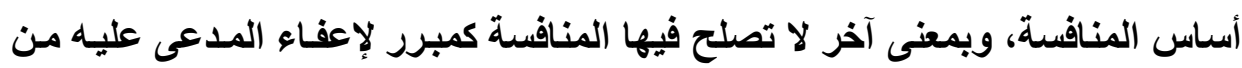
المسئولية عن التدخل في العلاقة التعاقدية.

الحالة الأولى: عندما يتم تلدخل المدعى عليه في العلاقة التعاقدية بسوع نيـة،

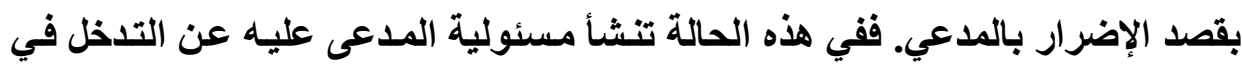
العلاقة التعاقدية، ويلتزم بتعويض المدعي المضرور، ولا تصلح المنافسة كمبرر أو فل فاله

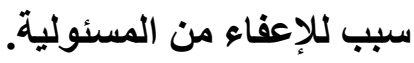
الحالة الثانية: إذا كان تلخل المدعى عليه في العلاقة التعاقدية بهاف جلب، أو سحب الحقوق التعاقدية الخاصة بالمدعي لنفسه. ففي هذه الحالة أيضا تنشأ مسئولية

(1) Charles E. Carpenter, previous reference, P. 760, 761.

(2) Steven W. Feldman, previous reference, P. 12. 
المدعى عليه عن التدخل في العلاقة التعاقدية، ويلتزم بتعويض المدعي المضرور، ولا تصلح المنافسة كمبرر أو سبب للإعفاء من المسئولية (1) .

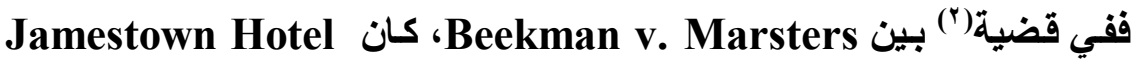
Corporation Jamestown 25 Cent وكالة حصرية بتمثيل القتدق في جميع أنحاء New England في مقابل ونيل في اليوم لكل سائح تجلبه شركة السياحة إلى القندق. فقـام المدعى عليه، وهو شركة سياحة منافسة، وقد كان على علم بوجود العقد بين الفندق وشركة السياحة المنافسة، بإقناع صاحب القندق وتحريضه على فسخ العقد مع شركة السياحة، بدعوى أنها شركة

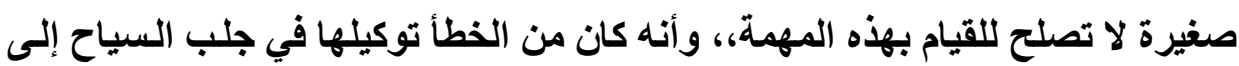
القندق، وقام المدعى عليه أيضا بإقناعه أنه الأجلر بالقيام بهذه المهمة وجلب السياح إلى الفتـلق. فحكمـت المحكمـة بمسئولية المـدعى عليه، ولـم تعتـد بالمنافسة كمبرر للإعفاء من المسئولية في هذه الحالة، نظرا لسوء نية المدعى عليه، وتعدده إلحاق

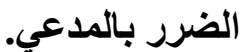

الحالة الثالثة: عندما يكون تدخل المدعى عليه في العلاقة التعاقديـة الخاصـة

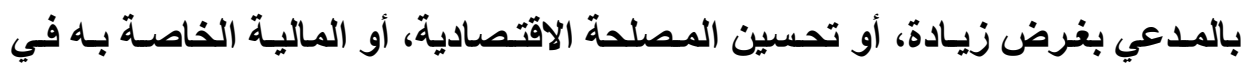

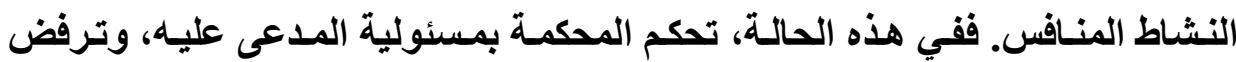
المبرر الخاص بالمنافسة، كوسيلة دفع أو نفي المسئولية(").

(1) Charles E. Carpenter, previous reference, P. 755.

(2) Beekman v. Marsters, 195 Mass. 205, 80 N. E. 817 (1907).

(3) Charles E. Carpenter, previous reference, P. 755. 
ففي قضية'(') بين R An W Hat Shop Co. v. Sculley تتلخص

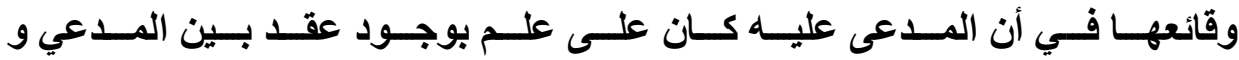

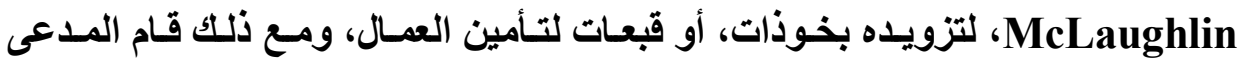
عليه بتحريض McLaughlin لفسخ عقده مـع المدعي، وتزويده بهذه الخـوذات

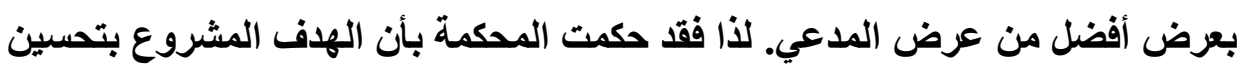
المصلحة الاقتصادية، أو المالية الخاصـة بالمدعى عليه لا تبرر التدخل المتعمد في لئي العلاقة التعاقدية الخاصة بالمدعي، والإضرار بحقوقه التعاقدية.

الحالة الرابعة: وهي التي يقوم فيها المدعى عليه بالتدخل في العلاقة التعاقدية

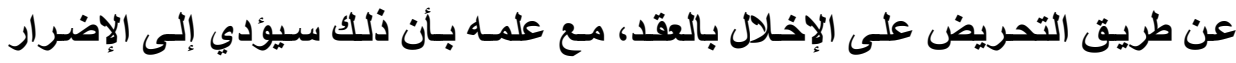

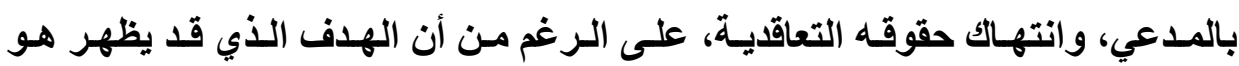
تحسين مصلحة الاقتصادية.

فهذا يعد في جوهره تـخلا متعـدا في العلاقة التعاقديـة للـدعي، وإضرارا بحقوقه التعاقدية، ولا يعتد هنا بالمنافسة كمبرر، أو كسبب للإعفاء من المسئولية عن العنائ

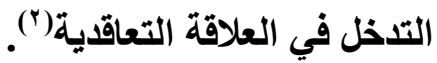

ففي قضية(") بين Glamorgan Coal Co. v. South Wales كان يمتلك المدعي مناجم فحم، وكان أجر عمال المنجم يبنى أو يقدر على أساس سعر بيع الفحم. خاف اتحاد عمال المناجم من تقليل الأجور، نتيجة

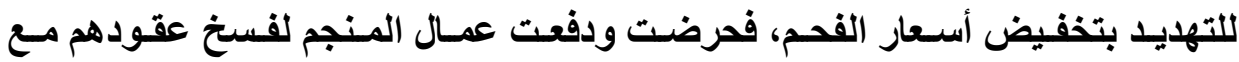

(1) R An W Hat Shop Co. v. Sculley, 98 Conn. 1, 118 Atl. 55 (1922).

(2) Charles E. Carpenter, previous reference, P. 756.

(3) Glamorgan Coal Co. v. South Wales Miners' Federation, (1903), 2 K. B. 545. Charles E. Carpenter, previous reference, P. 756. 


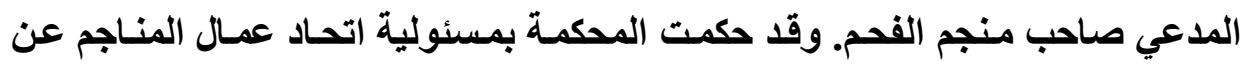

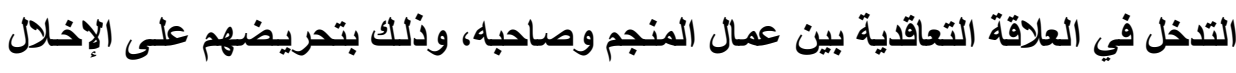
بعقودهم مع صاحب المنجم المدعي، لأن المدعى عليه، وهو الاتحاد، كان على علم بأنه التها

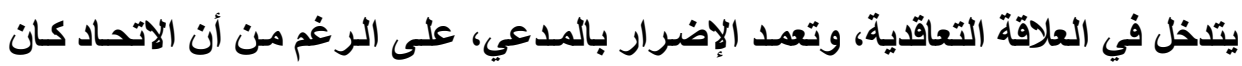

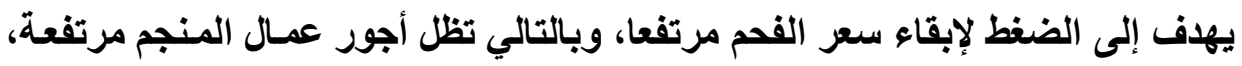
إلا أن المحكمة لم تعتد، أو تعترف بهذا المبرر لإعفاء اتحاد عمال المنجم من المسئولية المالية

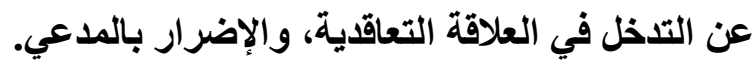
نخلص مما تقدم إذن إلى أن المنافسة المشروعة تصلح مبررا أو عذرا لإعفاء

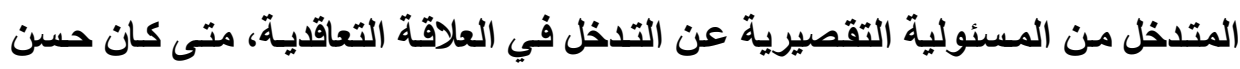
النية، لم يقصد الإضرار بالمدعي، أو انتهاك حقوقه التعاقدية. 


\section{الخاتمة}

ختاما، وبعد الانتهاء من بحثنا هذا، توصلنا إلى النتائج الآتية:

إن المسئولية التقصيرية في القانون الأمريكي لا تعرف قواعد عامة، أو نظرية

واحدة للمسئولية التقصيرية، كما هو الحال في القـانون المصري، وإنمـا يحدد القانون

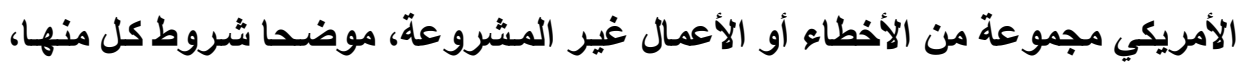
والآثار المترتبة عليها، فلا يجمع هذه الأعمال أصل عام، أو أركان، أو شروط مشترك. وعلى ذلك اهتم القانون الأمريكي، وكذلك القضاء، بالمسئولية التقصيرية عن التلخل في العلاقة التعاقدية كصورة مستقلة من صور المسئولية، نظر الأهمية الحقوق التعاقدية، والعلاقات التجارية للأشخاص.

ويتقرر هذا النوع من المسئولية بتوافر بعض الأركان، أو الشروط المميزة أهمها: وجود عقد قائم وصحيح، وعلم المتدخل بوجود هذا العقد، والتدخل المتعدد في العلاقة التعاقديـة، والضرر الواقع على المتعاقد المدعي نتيجة لهـذا التدخل، وعلاقة فئة السببية بين التدخل في العلاقة التعاقدية والضرر.

ولقد اختلفت الولايات القضائية الأمريكية في حمم التدخل في العلاقة التعاقدية

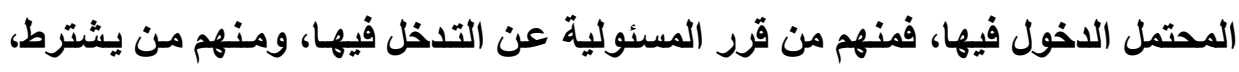
حتى تتقرر المسئولية، أن يقع التدخل في علاقة تعاقدية قائمة وصحيحة. كما اختلفت أيضا الولايات القضائية في حمم التدخل في العلاقة التعاقدية الناتج عن إهمال المتدخل، فمنهم من قرر المسئولية عن هذا التدخل، ومنهم من يشترط، حتى تتقرر المسئولية، أن يكون التدخل متعمد، بقصد الإضرار بالحقوق التعاقدية للمدعي. 


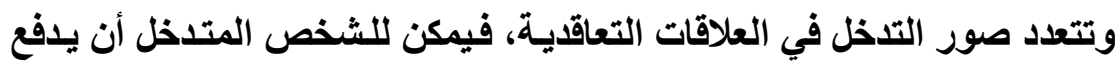

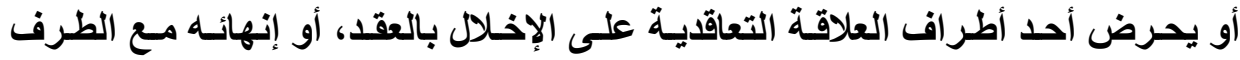

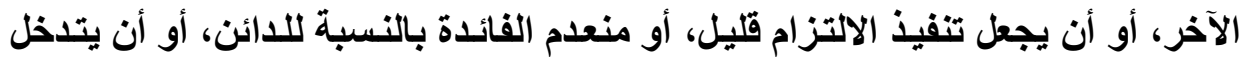

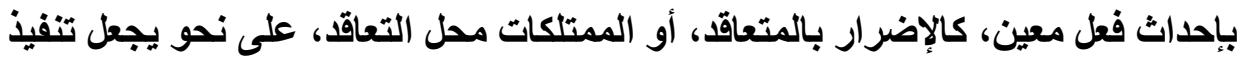
الالتزام التعاقدي أكثر صعوية، أو إرهاق للمدين، أو أن يجعل تنفيذه أمر مستحيل. ومتى تقررت المسئولية التقصيرية للمتلخل في العلاقة التعاقدية، تقوم معظم

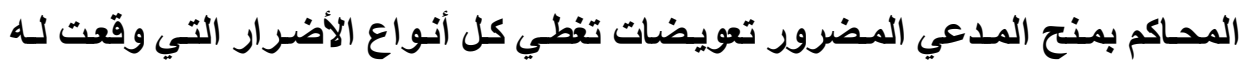
بسبب تدخل المدعى عليه في العلاقة التعاقدية، فهي تعوضه عن الأضرار الفعلية التي

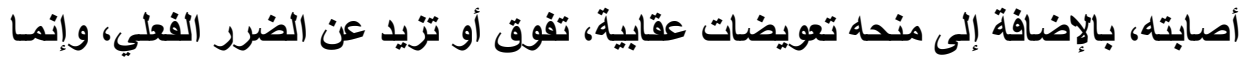
يدفعها المدعى عليه عقابا له على فعله غير المشروع. وتتعدد مبررات إعفاء المتـخل مـن المسئولية التقصيرية عن التدخل في العلاقة التعاقدية، وذلك منى قام بالتدخل بهدف حماية حقوقه التعاقدية، ومتى تم ذلك

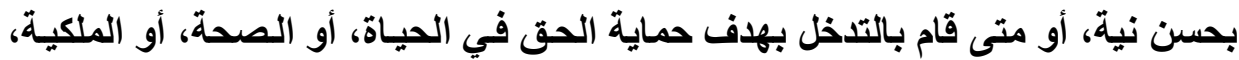
أو السمعة، أو تدخل بهذف النصيحة، أو بهاف المنافسة المشروعة، كل هذا بشرط أن يكون تدظله قد تم بحسن نية، لم يقصد به الإضرار بالمدعي.

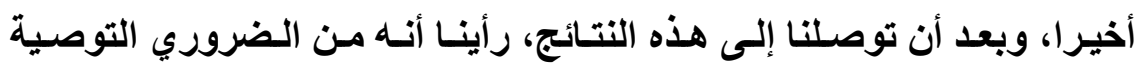

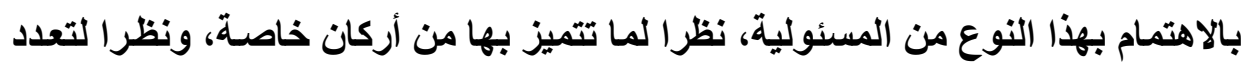
صورها، وخطورتها، وما تثيره من مشاكل قانونية، وعملية. 


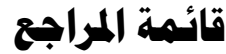

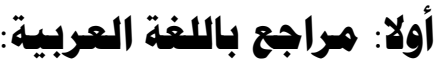

1- أحمد محمد عطيـة، نظريـة التعدي كأسـاس للمسئولية المدنيـة الحديثة، دراسـة

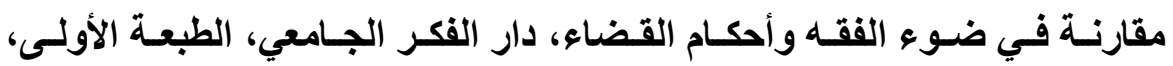
r...v

r- رمزي رشـاد عبد الرحمن، أثر سوء النية على عقود المعاوضـات في القانون

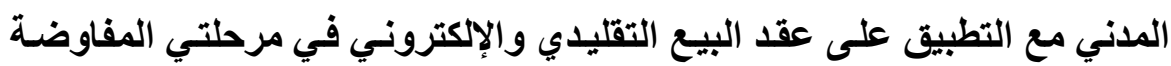

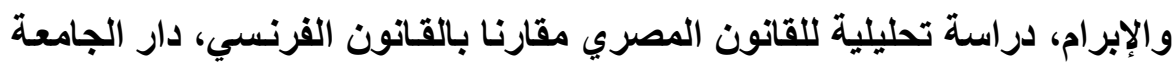

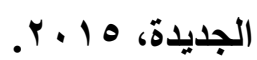

ץ- ز زهير بن زكريـا حرح، الخطأ في المسئولية المدنية، دراسة مقارنـة في النظام

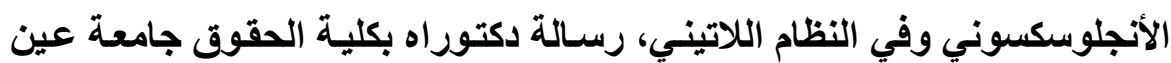

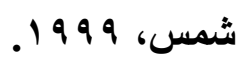

ــ شريف الطباخ، التعويض عن الإخلال بالعقد، التطبيق العملي للمسئولية المدنية

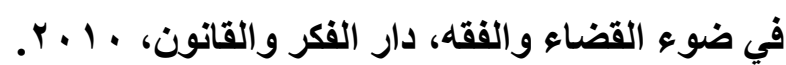
هـ عبد الحكم فوده، الخطأ في نطاق المسئولية التقصيرية، دار الفكر الجـامعي،

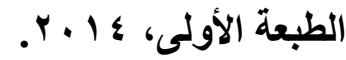

צ- عبد الهادي فوزي العوضي، الخطأ المكسب في إطار المسئولية المدنية، دراسة

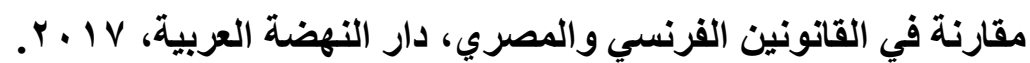
محسن عبد الحميد البيه، حقيقة أزمسة المسئولية المدنية ودور تأمين المسئولية،

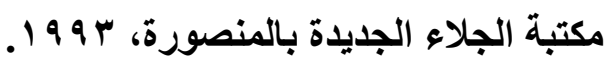

VP. مجلة البحوث القانونيت والإقتصاديت 
^- محسن عبد الحميد البيه، التضامن والتضامم في قضاء محكمة الاستئناف العليا الكويتية مقارنـا بالقضاء الفرنسي والمصري، مكتبـة الجلاء الجديدة بالمنصورة،

$$
\text { بلدون تاريخ نشر. }
$$

9- محمد السعيد رشـدي، الخطاً غير المغتفر، سـوء السلوك الفـاحش والمقصود، دراسة في القوانين: الفرنسي والمصري والكويتي، منشأة المعارف بالإسكندرية، .$r \cdot \Lambda$

• 1 ـ محمد عبد الظاهر حسين، المسئولية التقصيرية للمتعاقد، دراسـة فقهية قضائية في العلاقة التبادلية بين نوعي المسئولية، دار النهضة العربية، ع ـ . ب. 1 ا - مصطفى عبد الحميد عدوي، الإخلال المدني، المسئولية التقصيرية في القانون الأمريكي، بدون ناشر، ؛ 999

\section{ثانيا: هراجع باللغة الإنبليزية:}

1- Alex B. Long, Attorney liability for tortious interference: Interference with contractual relations or interference with the practice of law?, Georgetown Journal Of Legal Ethics, Spring 2005.

2- Amir Nezar, Reconciling Punitive Damages with Tort Law's Normative Framework, The Yale Law Journal, 121:678, 2011.

3- Barbara Tuttle Gamer, The agent's privilege to interfere intentionally with contractual relations: A reappraisal of California Law, California Western Law Review, Vol. 12, 1976. 
4- Benjamin C. Zipursky, A theory of punitive damages, Texas Law Review, Vol. 84:105, 2005.

5- Brand Lawless Cooper, Civil conspiracy and interference with contractual relations, Loyola Of Los Angeles Law Review, Vol. 8, 1975.

6- Catherine M. Sharkey, The future of class wide punitive damages, University of Michigan Journal of Law Reform, Vol. 46:4, 2013.

7- Charles B. Vincent, The handling of a claim for tortious interference with an at- will employment contract in the Delaware State Courts versus the Delaware District Court, Delaware Law Review, 2011.

8- Charles E. Carpenter, Interference with contract relations, Harvard Law Review, Vol. 41, No. 6, April 1928.

9- Clark A. Remington, Intentional interference with contract and the doctrine of efficient breach: Fine tuning the notion of the contract breacher as wrongdoer, Buffalo Law Review, Vol. 47, 1999.

10- Dan B. Dobbs, Tortious interference with contractual relationships, Arkansas Law Review, Vol. 34: 335, 1980.

11- Diane J. Klein, Treaties and domestic law after Medell'In v. Texas: Article: "Go west, Disappointed Heir": Tortious interference with expectation of inheritance- A survey with analysis of State approaches in the Pacific States, Lewis and Clark Law School Law Review, Spring, 2009. 
12- Fowler V. Harper, Interference with contractual relations, Inducing breach of contract, Northwestern University Law Review, Vol. 47, 1953.

13- Fred S. McChesney, Tortious interference with contract versus "Efficient" Breach: Theory and Empirical Evidence, The University of Chicago, The Journal of Legal Studies, January 1999.

14- Gary D. Wexler, Intentional interference with contract: Market efficiency and individual liberty considerations, Connecticut Law Review, Vol. 27:279, 1994.

15-Gary Myers, The differing treatment of efficiency and competition in Antitrust and Tortious interference law, Minnesota Law Review, Vol. 77: 1097, 1993.

16- Gina M. Grothe, Interference with contract in the competitive marketplace, William Mitchell Law Review, Vol. 15, 1989.

17- Gregory J. Sextro, Note, Corporate insurability of punitive damages arising from employee acts, the journal of corporation law, 2001.

18- Helmut Koziol and Vanessa Wilcox, Punitive damages: Common law and civil law perspectives, Springer Wien New York, Tort and insurance law, Vol. 25, April 2009.

19- H. Gerald Chapin, Interference with contractual rights as constituting a tort, West publishing company, New Jersey Law Review, 1915. 
20- James B. Sales, The tort of interference with contract: An argument for requiring a valid existing contract to restrain the use of tort law in circumventing contract law remedies, Texas Tech Law Review, Vol. 22: 123, 1991.

21- James M. Underwood, Road to nowhere or jurisprudential U-Tern? The intersection of punitive damage class actions and the due process clause, 66 Wash. And Lee Law Review $763,2009$.

22- Jeanette Andersson, Interference with contractual relations, Juridiska institutionen, Programmet for Juris Kandidatexamen, 1998.

23- Jerry C. Estes, Expanding horizons in the law of torts, Tortious interference, Drake Law Review, Vol. 23, January 1974.

24- Jill Wieber Lens, Procedural due process and predictable punitive damage awards, Brigham Young University Law Review, 2012.

25- John D. Long, should punitive damages be insured? The Journal of Risk and Insurance, No date.

26- John J. Fargo, Medical data privacy: Automated interference with contractual relations, Buffalo Law Review, Vol. 25, 1976.

27- Leonard J. Long, An Uneasy Case for a Tort of Negligent interference with Credit Contract, Law Review Association of the Quinnipiac University School of Law, 2003. 
28- Madeleine Tolani, U.S. punitive damages before German courts: A comparative analysis with respect to the order public, Annual survey of INT'L and COMP. Law, Vol. XVII, 2011.

29- Matthew A. Hood, When two worlds collide: Problems surrounding the business judgment rules as a privilege in tortious interference with contractual relations actions in Illinois, Board of Trustees of Southern Illinois University, Southern Illinois University Law Journal, Spring, 2007.

30-Odette Woods, Tort law, Tortious interference with contract: The Arkansas supreme court clarifies who has the burden and what they have to prove, Mason v. Wal-Mart Stores, Inc., 333 Ark. 3, 969 S.W.2d 160 (1998), University of Arkansas at Little Rock Law Review, Spring, 1999.

31-Peter Edmundson, Sidestepping limited liability in corporate groups using the tort of interference with contract, Melbourne University Law Review Association, Inc., April 2006.

32- Ronen Perry, Economic loss, Punitive damages, And the EXXON Valdez litigation, Georgia Law Review, Vol. 45:409, 2011.

33-Sandra S. Baron, Hilary Lane, and David A. Schulz, Tortious interference: The limits of Common Law liability for Newsgathering, William and Mary Bill of Rights Journal, Vol. 4:3, 1996. 
34- Steven W. Feldman, Tortious interference with contract in Tennessee: A practitioner's guide, The University of Memphis Law Review, Winter, 2001.

35- Thomas H. Cohen, Punitive damage awards in large countries 2001, Civil justice survey of State courts 2001, U.S. department of justice, March 2005.

36- W. Prosser, Law of torts, third edition, 1964.

37- Yu Yamazaki, Preliminary agreements as contracts: facilitating socially desirable transactions using the doctrines of injunction, disgorgement, and tortious interference, New York University Journal of Law and business, Fall 2012. 